NBSIR 84-3011

\author{
Alll0b $0 \exists \exists 750$
}

THERMAL AND MECHANICAL PROPERTIES OF POLYURETHANE FOAMS AND A SURVEY OF INSULATING CONCRETES AT CRYOGENIC TEMPERATURES

National Bureau of Standards U.S. Department of Commerce

Boulder, Colorado 80303

April 1984

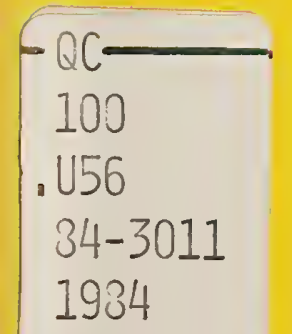




\section{THERMAL AND MECHANICAL PROPERTIES OF POLYURETHANE FOAMS AND A SURVEY OF INSULATING CONCRETES AT CRYOGENIC TEMPERATURES}

\section{L.L. Sparks*}

J.M. Arvidson* *

Chemical Engineering Science Division*

Center for Chemical Engineering*

Fracture and Deformation Division* *

Center for Materials Science**

National Sureau of Standards

U.S. Department of Commerce

Bouilder, Colorado 80303

April 1984

Prepared for

Gas Research Institute

8600 West Bryn Mawr Avenue

Chicago, Illinois 60631

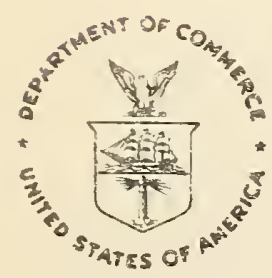

U.S. DEPARTMENT OF COMMERCE, Malcolm Baldrige, Secretary 
THERMAL AND MECHANICAL PROPERTIES OF POLYIJRETHANE FOAMS

AND A SURVEY OF INSULATING CONCRETES AT CRYOGENIC TEMPERATURES

\author{
FINAL REPORT \\ (January 1979 - February 1984) \\ Prepared by \\ L. L. Sparks* and J. M. Arvidson ${ }^{\star}$ \\ *Chemical Engineering Science Division \\ $\star *$ Fracture and Deformation Division \\ National Bureau of Standards \\ Boulder, Colorado 80303
}

For

GAS RESEARCH INSTITIJTE

Grant No. 5081-352-0425

GRI Project Manager

Dr. Kiran Kothari

Environment and Safety Department

April 1984 

LEGAL NOTICE This report was prepared by National Bureau of Standards as an account of work sponsored by the Gas Research Institute (GRI). Neither GRI, members of GRI, nor any person acting on behalf of either:

a. Makes any warranty or representation, express or imnlied, with respect to the accuracy, completeness, or usefulness of the information contained in this report, or that the use of any apparatus, methor, or process disclosed in this report may not infringe privately owned rights; or

b. Assumes any liability with respect to the use of, or for damages resulting from the use of, any information, apparatus, method, or process disclosed in this report. 



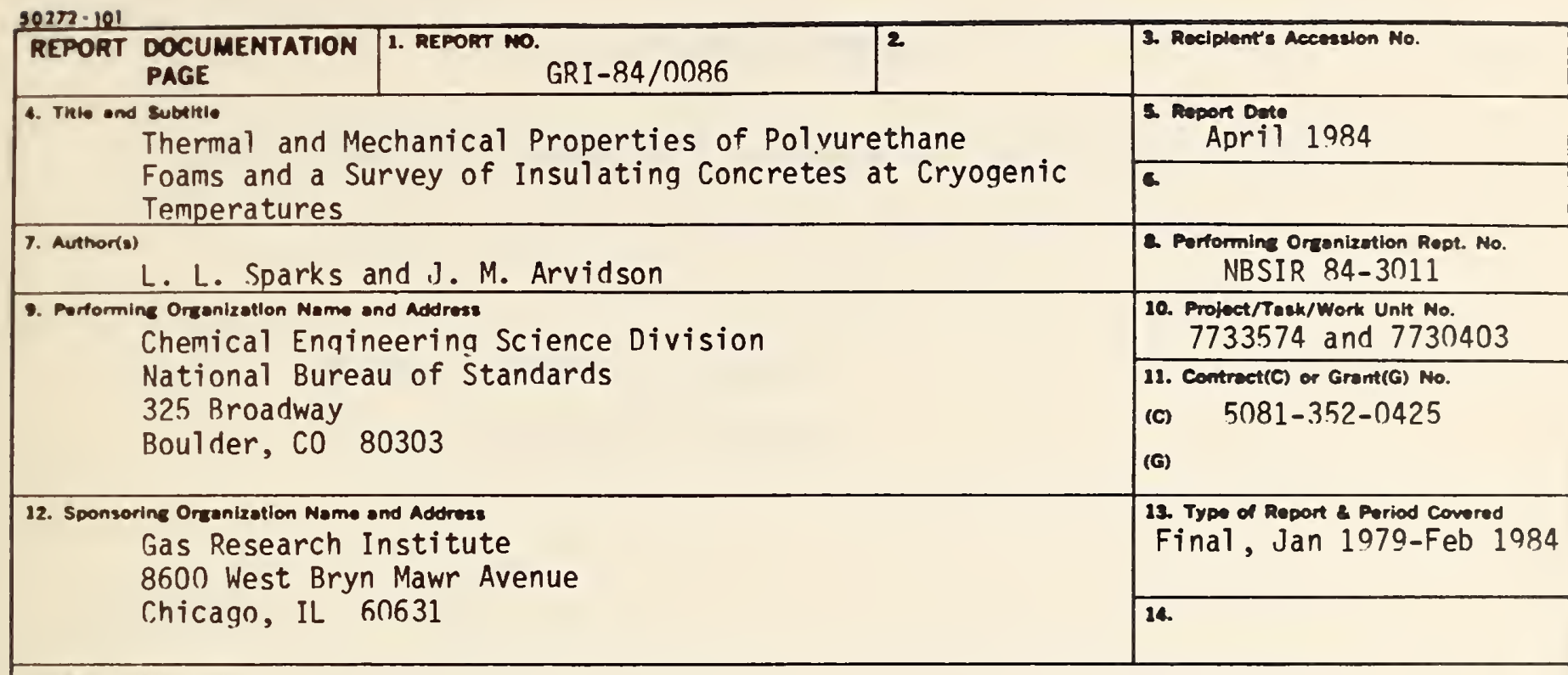

15. Supplementery Notes

16. meatroct fhermal and mechanical properties of expanded plastics, foams, are reported. The system sturied was rigid, closed cell, CCl 3 blown, polyether based polyurethane. The primary temperature range of study was 100 to $300 \mathrm{~K}$; however, several properties were determined to $4 \mathrm{~K}$. The nominal densities of the foams tested were 32 , 64 , and $96 \mathrm{~kg} / \mathrm{m}^{3}$. Properties reported are thermal conductivity, thermal expansion, strength and moduli in tension and in compression, proportional limit, yield strength, ultimate strenath, and shear strength. Physical properties were determined both paraliel and perpendicular to the orthogonal axes of the bulk supplies. The gas content of the specimens was determined using a gas chromatograph-mass spectrometer and with a gas displacement pycnometer. Empirical procedures for estimatina the temperature dependent thermoohysical properties wer developed. These procedures are based on the experimental data and utilize the character ization parameters for molar gas concentration, qas pressure, and cell morpholoay.

Regulations affecting vapor dispersion in the area around 1 iquefied natural gas facilities make it attractive to construct dikes and impounding areas out of materials having low thermal conductivities. Several insulating concretes have the general properties required for such applications. Screenina tests were done to determine the thermal conductivity, modulus of rupture, and the compressive strength of several polvester based materials with glass bead or perlite aqgreqate and of portland cement based materials wit vermiculite or polystyrene aggregate. A bibliography resulting from an extensive literature survey of lightweight concretes is presented. Seven of the references which were particularly applicable are presented in annotated form.

17. Documomt Analysis a. Deseriptore

cell size; compressive strength; elonqation; flexural strength; foam; glass head; insulation; low temperature; mechanical properties; morlulus of rupture; perlite; polyester; Dolymer concrete; polystyrene; portland cement; proportional limit; shear strength; tensile strength; thermal conductivity; thermal expansion; vermiculite; yield strength; Young's modulus.

b. Idantifiers/Opan-Ended Terms

c. COSATI Field/Group

18. Avollability Statemen:

Unlimited; NTIS, Springfield, VA 22161

\begin{tabular}{|c|c|c|}
\hline & $\begin{array}{l}\text { Socurtty Cless (This Ropores } \\
\text { UNCLASSIF IED }\end{array}$ & $\begin{array}{c}\text { 21. No. of Pacen } \\
160\end{array}$ \\
\hline 20 & $\begin{array}{l}\text { Security Clomes (This Pans) } \\
\text { UNCLASSIF IED }\end{array}$ & 2. Price \\
\hline
\end{tabular}





\section{RESEARCH SUMMARY}

Title Thermal and Mechanical Properties of Polyurethane Foams and a Survey of Insulating Concretes at Low Temperatures

Contractor National Bureau of Standards

GRI Grant Number 5081-352-0425

Report January 1979 - February 1984

Period (Final Report)

Objective To determine the thermal and mechanical properties of polyurethane foams and, whenever possible, to develop predictive techniques for the low temperature properties. To survey existing data for and to conduct screening tests on several insulating concretes in order to allow selection of the most viable candidate materials for further use and development. The temperature range of interest for both foams and concretes is that encountered in the transfer and storage of liquefied natural gas (LNG).

Technical Perspective

Expanded plastics or foams are used extensively as thermal insulation materials in liquefied fuel facilities. The widespread use of these materials can be attributed to low thermal conductivity, high strength-to-weight ratio, low cost of production, and ease of installation. The properties of foam insulations, which are 
essential to the design of facilities and production of foam, are not adequately predictable at this time. The needed predictability must be based on either theoretical or empirical representations that include the dependence on temperature and the effects of critical parameters such as cell size, gas content, and density.

Regulations concerning vapor dispersion in the event of a spill at a LNG storage facility make it attractive to use an insulating material in the construction of dikes and impounding areas. Several types of insulating concretes are candidates for such applications. Identification of one or more of these materials, along with the development of an adequate data base for the selected materials, is necessary for confident design.

Results The effort involving plastic foams has resulted in the following experimental data for each of the three polyurethane foams studied: thermal conductivity, thermal expansion, strength and moduli in compression and in tension, proportional limit, yield strength, ultimate strength, and shear strength. Foam specimen densities were nominally 32,64 , and $96 \mathrm{~kg} / \mathrm{m}^{3}$ and the basic temperature range of the study was 100-300 K. Empirical techniques were established to predict thermal conductivity, thermal expansion, and compressive and tensile strength and moduli. The empirical nature of these relationships and the small number of foam systems involved in their development mean that applicability to polyurethane foams in general has not been established. 
studied depend, in varying degrees, on cell gas, morphology, and chemical composition of the resin.

The effort directed to insulating concretes is a study of these materials, as a class, for applications to dikes and impounding areas at cryogenic temperatures. The literature survey resulted in very limited data applicable to the projected use of these materials. An experimental screening program was conducted on three polyester resins with glass-bead and periite fillers and two portland-cement mixes with vermiculite and polystyrene fillers. The screening consisted of determining the thermal conductivity at several temperatures between 76 and $285 \mathrm{~K}$ (high vacuum environment) and determining the modulus of rupture (MOR) and compressive strength at 76 and $300 \mathrm{~K}$.

ASTM standard methods C78 and C513 were used to determine MOR and compressive strength respectively at both ambient and cryogenic temperatures.

Project A large data base on thermophysical properties of foams at cryoImpl ications

genic temperatures has been generated. Empirical relationships were developed to predict themal conductivity, thermal expansion, and strength properties of the foams utilizing experimental data. These parameters will be used in insulation design for cryogenic fluid transfer pipes and storage tanks. 
A survey of existing data for insulating concretes has been completed. The survey yielded approximately 300 pertinent references, of which 30 contained data applicable to LNG facilities. Screening tests, done to supplement data from the literature, have been completed. These tests resulted in comparative data for thermal conductivity, modulus of rupture and compressive strength for several polyester-based materials with glass bead or perlite aggregate and for portland-cement-based materials with vermiculite or polystyrene aggregate. Thermophysical properties and low water absorption required for dike insulation materials recommend polymer-based materials over portland-cement-based materials. Portland-cement-based materials could also be produced which, with waterproofing and proper grading of dike/basin surfaces, would be suitable.

Technical The thermophysical properties of expanded plastics depend on Approach morphology, gas content, and chemical composition. A wide variety of techniques have been used to determine these parameters. The most fruitful methods are gas chromatography/mass spectrometry, optical analysis of polarized photomicrographs and pycnometry. These analyses yield statistical information on cell size, cell shape and orientation, and cellular gas content. In addition to specimen characterization, the experimental study consisted of determining thermal conductivity (ASTM C177 dry-nitrogen environment), $\Delta \mathrm{L} / \mathrm{L}$ in an optical-lever dilatometer (helium-gas environment), and the mechanical properties in a system utilizing a specially designed capacitance extensometer (helium-gas environment). All properties 
From a literature survey and from limited experiments, six potential materials for dike insulation at LNG facilities have been identified. Two of the recommended materials composed of polymer binder with perlite or glass nodules as the aggregate are being extensively tested in a GRI-sponsored project at Brookhaven National Laboratory.

GRI Project Manager

Kiran M. Kothari

Project Manager, LNG Safety 
Page

GRI Disclaimer...................................

Research Summary ........................... vii

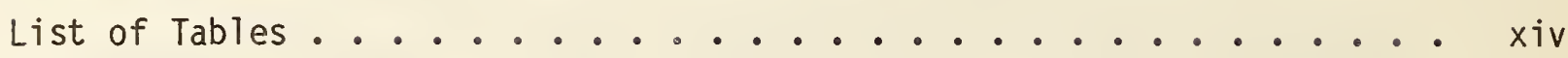

List of figures ...................................

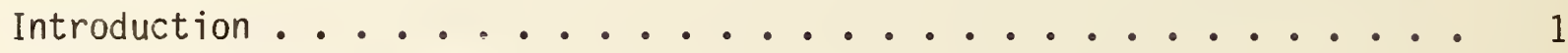

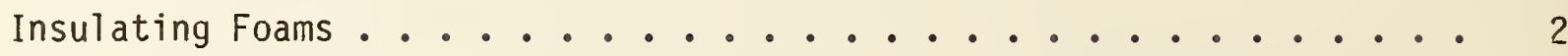

Overall Project objective (IF) ..................... ?

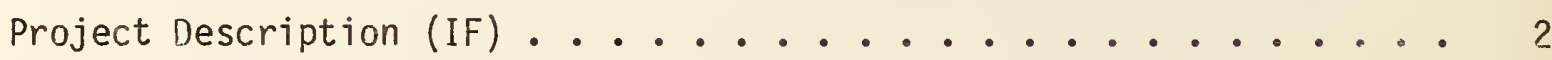

Project Rationale and Projected Benefits (IF) ........ 5

Technical Discussion (IF) ..................... 6

Work PTan $(\mathrm{IF}) \ldots \ldots \ldots \ldots$

Work Performed and Experimental Results (IF) . . . . . . . 8

Discussion of Results and Modeting (IF) . . . . . . . 70

Major Achievements (IF) .................. 88

Major Technical Problems (IF) . . . . . . . . . 89

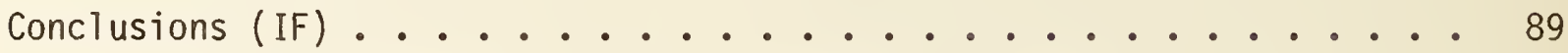

References (If) ......................... 91

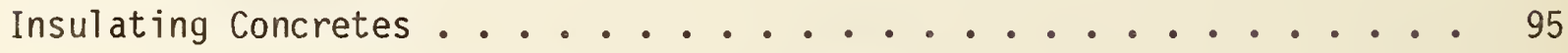

Overall Project Objective (IC) . . . . . . . . . 95

Project Description (IC) . . . . . . . . . 95

Project Rationale and Projected Benefits (IC) . . . . . . . 96

Technical Discussion (IC) . . . . . . . . . . 97

Work Plan (IC) ........................ 97

Work Performed and Results (IC) . . . . . . . . 97

Discussion of Results (IC) . . . . . . . . 102 
Table of Contents (continued)

Page

Major Achievements (IC) . . . . . . . . . 111

Major Technical Problems (IC) . . . . . . . . . . 111

Conclusions (IC) . . . . . . . . . . . . . 111

Recommendations (IC) . . . . . . . . . . 112

References (IC) ................................. 114

Annotated Bibliographies (IC) . . . . . . . . . 134 


\section{List of Tables}

$\underline{T a b l e}$

Page

1 Maximum intercepted cell dimensions parallel to the orthogonal principal axes of the $X Y, X Z$, and $Y Z$ planes for four specimens of PU32 and two specimens each of PU64 and PU96. Locations of the specimens are indicated in figure $2 .$.

2 Ratios of averaged maximum intercepted cell dimensions parallel to the orthogonal principal axes of the $X Y, X Z$, and $Y Z$ planes for four specimens of PU32 and two specimens each of PU64 and PU96. Locations of the specimens are indicated in figure 2......................

3 Intercepted cell section area computed from cell wall intercept data for two specimens each of PU32, PU64, and PU96. The method of computation follows that described by Schael (1967). Locations of the specimens are indicated in figure 2 .

4 Results of gas comparison pycnometer (GCP) characterization of PU32, PU64, and PU96. Comparable results from optical evaluations of the same materials are also given .......

5 Cell gas composition of PU32, PU64, and PU96 (Barkley, 1983). One standard deviation for the $\mathrm{CC}_{3} \mathrm{~F}$ contents is $\pm 10 \%$.....

6 Average thermal conductivity as a function of average temperature for a $32-\mathrm{kg} / \mathrm{m}^{3}$ polyurethane foam . . . . . . . . . .

7 Average thermal conductivity as a function of average temperature for $64-$ and $96-\mathrm{kg} / \mathrm{m}^{3}$ polyurethane foams

8 Polynomial coefficients representing the thermal expansion of $32-, 64-$, and $96-\mathrm{kg} / \mathrm{m}^{3}$ polyurethane foams. Reference tempera-

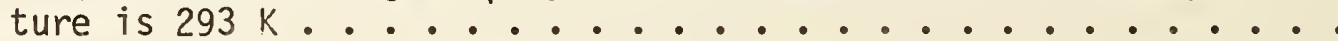

9 Thermal expansion and coefficient of thermal expansion for a

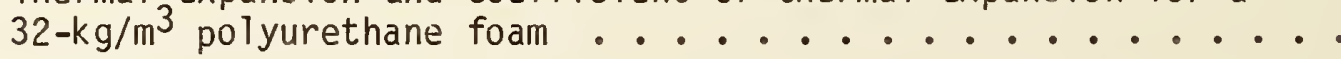

10 Thermal expansion and coefficient of thermal expansion for a

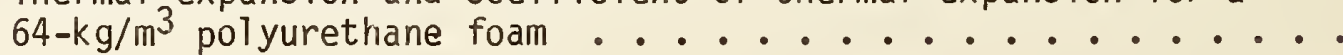

11 Thermal expansion and coefficient of thermal expansion for a $96-\mathrm{kg} / \mathrm{m}^{3}$ polyurethane foam ................

12 Summary of tensile test results for a $32-\mathrm{kg} / \mathrm{m}^{3}$ polyurethane foam (average values) ...................

13 Summary of compressive test results for a $32-\mathrm{kg} / \mathrm{m}^{3}$ polyurethane foam (average values) .................

14 Summary of shear strength test results for a $32-\mathrm{kg} / \mathrm{m}^{3}$ polyurethane foam (average values) 


\section{List of Tables}

Table

Page

15 Summary of tensile test results for a $64-\mathrm{kg} / \mathrm{m}^{3}$ polyure-

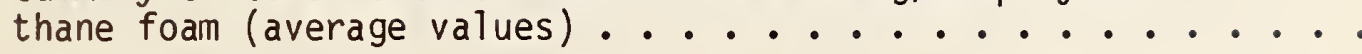

16 Summary of compressive test results for a $64-\mathrm{kg} / \mathrm{m}^{3}$ polyure-

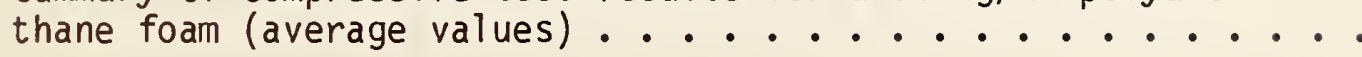

17 Summary of shear strength test results for a $64-\mathrm{kg} / \mathrm{m}^{3}$ polyurethane foam (average values) ............

18 Summary of tensile test results for a $96-\mathrm{kg} / \mathrm{m}^{3}$ polyurethane

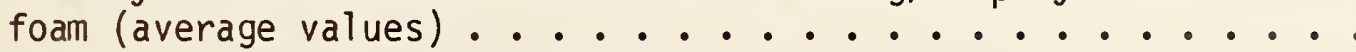

19 Summary of compressive test results for a $96-\mathrm{kg} / \mathrm{m}^{3}$ polyure-

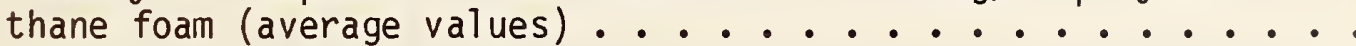

20 Summary of shear strength test results for a $96-\mathrm{kg} / \mathrm{m}^{3}$ polyure-

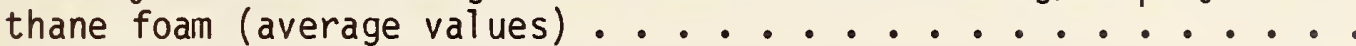

21 Computed values of thermal conductivity components based on initial vapor-pressure temperatures as determined from

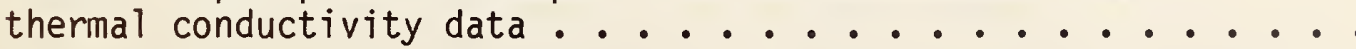

22 Pressure-induced strain parallel to the measurement direction calculated as a function of internal and external pressures and Young's moduli (longitudinal). External pressures were $89.3 \mathrm{kPa}$ for PU32 and PU96 and $84.0 \mathrm{kPa}$ for PU64 .........

23 Thermal contraction of the resins and the calculated transverse thermal contractions of PU32, PU64, and PU96 as determined from the pressure-induced stress and Young's moduli (transverse) ...

24 Parameters needed to estimate the thermophysical properties of polyurethane foams as a function of temperature ........

25 Industrial sources of information and/or materials used in the NBS/GRI survey of insulating concretes. This list is not comprehensive in regard to companies involved with lightweight concretes and no endorsement is implied ..........

26 Density, thermal conductivity (k), compressive strength (CS), and the ratio $Q=C S / K$ for the lightweight concretes tested at NBS and for several materials reported in the literature. The data are for $295 \mathrm{~K}$ 


\section{List of Figures}

Figure

Page

1 Tasks associated with the insulating foam project ...... 3

2 Bulk supplies of polyurethane foam and orientation of axes. Numbered rectangles indicate areas used for characterization . . 9

3 Configuration of the planes studied by optical methods . . . 10

4 Orientation of the elongated cell axes. These results are from optical examinations of the bulk supplies of these materials

5 Schematic of the system used to obtain samples of cell gas from fluorocarbon blown polyurethane foams .......

6 Schematic of the guarded-hot-plate themal conductivity apparatus ...................

7 Schematic of guarded-hot-plate specimen configuration and

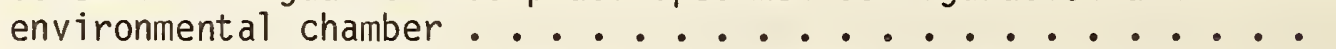

8 Total apparent thermal conductivity of fluorocarbon blown polyurethane foams of nominal densities 32,64 , and $96 \mathrm{~kg} / \mathrm{m}^{3} \ldots \ldots \ldots \ldots \ldots \ldots$

9 Schematic of dilatometer developed for inhomogeneous, aniso-

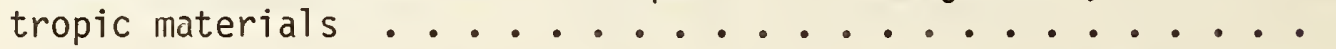

10 Thermal expansion of a $32-\mathrm{kg} / \mathrm{m}^{3}$ polyurethane foam specimen. Experimental data are represented by discrete points and the solid line represents a three-term polynomial fit to these data. The reference temperature is $281.997 \mathrm{~K} \ldots \ldots$

11 Thermal expansion of a $64-\mathrm{kg} / \mathrm{m}^{3}$ polyurethane foam specimen. Experimental data are represented by discrete points and the solid line represents a three-term polynomial fit to these data. The reference temperature is $295.180 \mathrm{~K}$........

12 Thermal expansion of a $96-\mathrm{kg} / \mathrm{m}^{3}$ polyurethane foam specimen. Experimental data are represented by discrete points and the solid line represents a three-term polynomial fit to these data. The reference temperature is $292.227 \mathrm{~K}$. . . . . . .

13 Results of three-term polynomial fits to the thermal expansion of $32-, 64-$, and $96-\mathrm{kg} / \mathrm{m}^{3}$ polyurethane foam specimens. Reference temperature is $293 \mathrm{~K} \ldots \ldots \ldots$

14 Coefficient of thermal expansion relationships resulting from temperature derivatives of three-term polynomial fits to thermal expansion data of $32-, 64-$, and $96-\mathrm{kg} / \mathrm{m}^{3}$ polyurethane foam specinens ................ 


\section{List of Figures (continued)}

Figure

Page

15 Extensometer systems which utilize the capacitance of concentric cylinders. Uniform and reduced section tensile specimen geometries are al so illustrated . . . . . . . . . . . .

16 Tensile Young's modulus versus temperature for a $32-\mathrm{kg} / \mathrm{m}^{3}$ polyurethane foam . . . . . . . . . . . . . . . .

17 Tensile test results: proportional limit, yield strength, and ultimate strength versus temperature for a $32-\mathrm{kg} / \mathrm{m}^{3}$ polyurethane foam . . . . . . . . . . . . . . . .

18 Tensile strain versus temperature for a $32-\mathrm{kg} / \mathrm{m}^{3}$ polyurethane foam

19 Compressive Young's modulus versus temperature for a $32-\mathrm{kg} / \mathrm{m}^{3}$ polyurethane foam .....................

20 Compression test results: proportional limit, yield strength, and maximum compressive strength versus temperature for a $32-\mathrm{kg} / \mathrm{m}^{3}$ polyurethane foam ............... . . .

21 Compressive strain versus temperature for a $32-\mathrm{kg} / \mathrm{m}^{3}$ polyurethane foam ..........................

22 Shear strength versus temperature for a $32-\mathrm{kg} / \mathrm{m}^{3}$ polyurethane foam

23 Tensile Young's modulus versus temperature for a $64-\mathrm{kg} / \mathrm{m}^{3}$ polyurethane foam ..................... .

24 Tensile strength versus temperature for a $64-\mathrm{kg} / \mathrm{m}^{3}$ polyurethane foam

25 Tensile strain versus temperature for a $64-\mathrm{kg} / \mathrm{m}^{3}$ polyurethane foam

26 Compressive Young's modulus versus temperature for a $64-\mathrm{kg} / \mathrm{m}^{3}$ polyurethane foam.

27 Compressive strength versus temperature for a $64-\mathrm{kg} / \mathrm{m}^{3}$ polyurethane foam ........................

28 Compressive strain as a function of temperature for a $64-\mathrm{kg} / \mathrm{m}^{3}$ polyurethane foam.

29 Shear strength versus temperature for a $64-\mathrm{kg} / \mathrm{m}^{3}$ polyurethane foam

30 Tensile Young's modulus versus temperature for a $96-\mathrm{kg} / \mathrm{m}^{3}$ polyurethane foam 


\section{List of Figures (continued)}

Figure

$\underline{\text { Page }}$

31 UItimate tensile strength versus temperature for a $96-\mathrm{kg} / \mathrm{m}^{3}$

polyurethane foam ................

32 Tensile strain versus temperature for a $96-\mathrm{kg} / \mathrm{m}^{3}$ polyure-

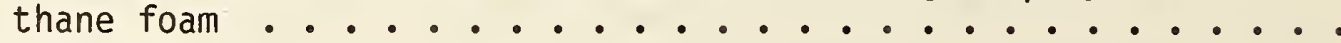

33 Tensile stress versus strain for a $96-\mathrm{kg} / \mathrm{m}^{3}$ polyurethane

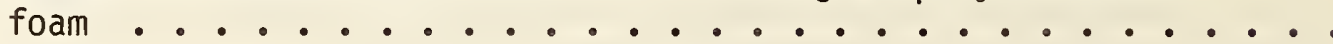

34 Compressive Young's modulus versus temperature for a $96-\mathrm{kg} / \mathrm{m}^{3}$

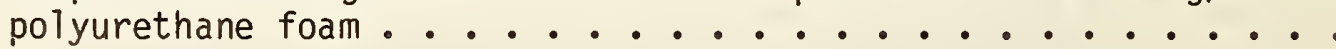

35 Compressive strength versus temperature for a $96-\mathrm{kg} / \mathrm{m}^{3}$ poly-

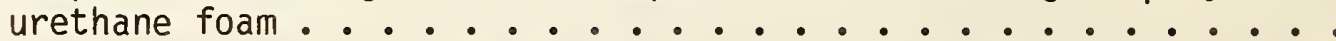

36 Compressive proportional limit versus temperature for a $96-\mathrm{kg} / \mathrm{m}^{3}$

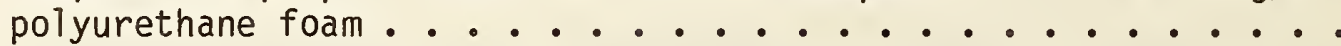

37 Compressive yield strength versus temperature for a $96-\mathrm{kg} / \mathrm{m}^{3}$ polyurethane foam ...............

38 Compressive strain versus temperature for a $96-\mathrm{kg} / \mathrm{m}^{3}$ polyurethane foam

39 Compressive stress versus strain for a $96-\mathrm{kg} / \mathrm{m}^{3}$ polyure-

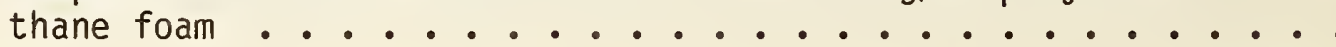

40 Shear strength versus temperature for a $96-\mathrm{kg} / \mathrm{m}^{3}$ polyure-

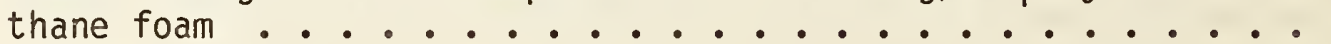

41 Thermal conductivity as a function of temperature for gases commonly found in polyurethane foams (Touloukian, Liley, and

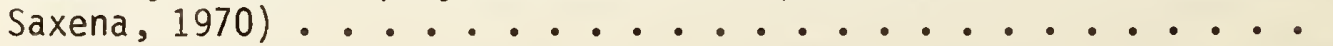

42 Parameters affecting the measured thermal expansion of expanded

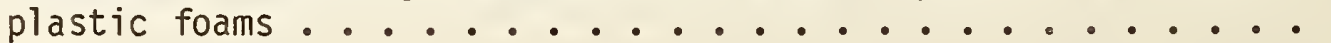

43 Longitudinal (experimental) and transverse (calculated) thermal contraction of PU32, PU64, and PU96 ...........

44 Calculated thermal contraction of polyurethane as a function of density with temperature as the parameter .........

45 Young's modulus of polyurethane foam in tension as a function of density with temperature as the parameter. The modulus obtained here must be modified by a function of $(H / W)$ for a specific material 


\section{List of Figures (continued)}

Figure

Page

46 Strength of polyurethane foams in tension as a function of density with temperature as the parameter. Strength obtained here must be modified by a function of $(\mathrm{H} / \mathrm{W})$ for a specific material .......................

47 Young's modulus of polyurethane foam in compression as a function of density with temperature as the parameter. The modulus obtained here must be modified by a function of $(H / W)$ for a specific material .................. .

48 Compressive strength of polyurethane foam as a function of density with temperature as the parameter. The strength obtained here must be modified by a function of $(H / W)$ for a particular material ... . . . . . . . . . . . .

49 Thermal conductivity as a function of temperature with moisture content (Lentz and Monfore, 1965) and density (Adams, 1969) as parameters ...................

50 Splitting strength as a function of temperature for an expanded shale concrete with density of $1554 \mathrm{~kg} / \mathrm{m}^{3}$ (Monfore and Lentz, 1962) . . . . . . . . . . . . . . . . .

51 Compressive Young's modulus as a function of temperature for an expanded shale concrete of density $1554 \mathrm{~kg} / \mathrm{m}^{3}$ (Monfore and Lentz, 1962) . . . . . . . . . . . . . . . . .

52 Compressive strength as a function of temperature for expanded shale/portland (Monfore and Lentz, 1962) and for several 1ightweight concretes at $295 \mathrm{~K}$ (MCClune and Moorhouse, 1981) ....

53 Thermal conductivity of several insulating concretes as a function of temperature. The testing environment was insulating vacuum .........................

54 Average compressive strength of several insulating concretes as/a function of temperature (determined at NBS)

55 Average modulus of rupture of several insulating concretes as a function of temperature (determined at NBS) . . . . . . . . 

Thermal and Mechanical Properties of Polyurethane Foams and a Survey of Insulating Concretes at Cryogenic Temperatures

\section{INTRODUCTION}

Safe and economical storage and transport of cryogenic fuels such as liquefied natural gas (LNG) depend to a large extent on the materials used in the construction of storage tanks, transfer terminals, liquefiers, pipelines, and ships. Thermal insulation constitutes a critical link in the materials for use in LNGand LPG (1iquefied petroleum gas)-oriented energy efforts because of the cryogenic nature of the liquids. Two types of insulating material are being studied --expanded plastics and lightweight concretes. Insulation systems utilizing expanded plastics (foams) are used in many LNG-oriented facilities. An insulating concrete can satisfy requirements for dike and impounding areas of LNG storage tanks.

The data bases and knowledge based on experience for both types of material being considered are inadequate for reliable design. Most data for insulating foams are based on essentially uncharacterized specimens. Consequently, it is not generally possible to reliably relate existing data to a particular foam. Inefficient overdesign and failures may occur because the material actually used is different than the material used to determine the design properties. Insulating concretes have not been used extensively in applications where they must be functional at cryogenic temperatures. There is not enough information available to allow a particular type of lightweight material to be chosen with confidence. Unanswered areas of concern are application difficulties, initial cost, maintenance costs, deterioration, and thermal and mechanical properties.

This project was designed to alleviate these difficulties. The portion of the project devoted to foams will be discussed first and will be identified by (IF) for insulating foams. Discussion of insulating concretes will follow and will be designated by (IC). 


\section{INSULATING FOAMS}

Overāll Project Objective (IF)

There are four major objectives of the foam project:

(1) To improve the existing data base and the test procedures relating to expanded plastics at iow temperatures.

(2) To develop test methods and characterization procedures for general application to foam insulations.

(3) To provide a basic understanding of the observed low-temperature behavior and to develop procedures that can be used to predict low-temperature properties of insulating polyurethane foams.

(4) To serve as a center for insulation information for GRI and associated users of cryogenic fuels.

Project Description (IF)

The work performed on insulating foams can be correlated with the major tasks shown in figure 1 .

(1) Assessment of Materials - A literature search was made. Companies and technical societies involved in the production and/or use of insulating foams were contacted. The results of this phase of the project were reported by Sparks $(1979,1980)$. Based on the information obtained, three densities of expanded polyurethane foam were chosen as materials for detailed study. The densities span the range normally used in insulating applications.

(2) Assessment of Methods - This effort was performed concurrent with task (1) since the same literature survey and industrial contacts were involved. With the exception of thermai conductivity, there are no existing standard test procedures 


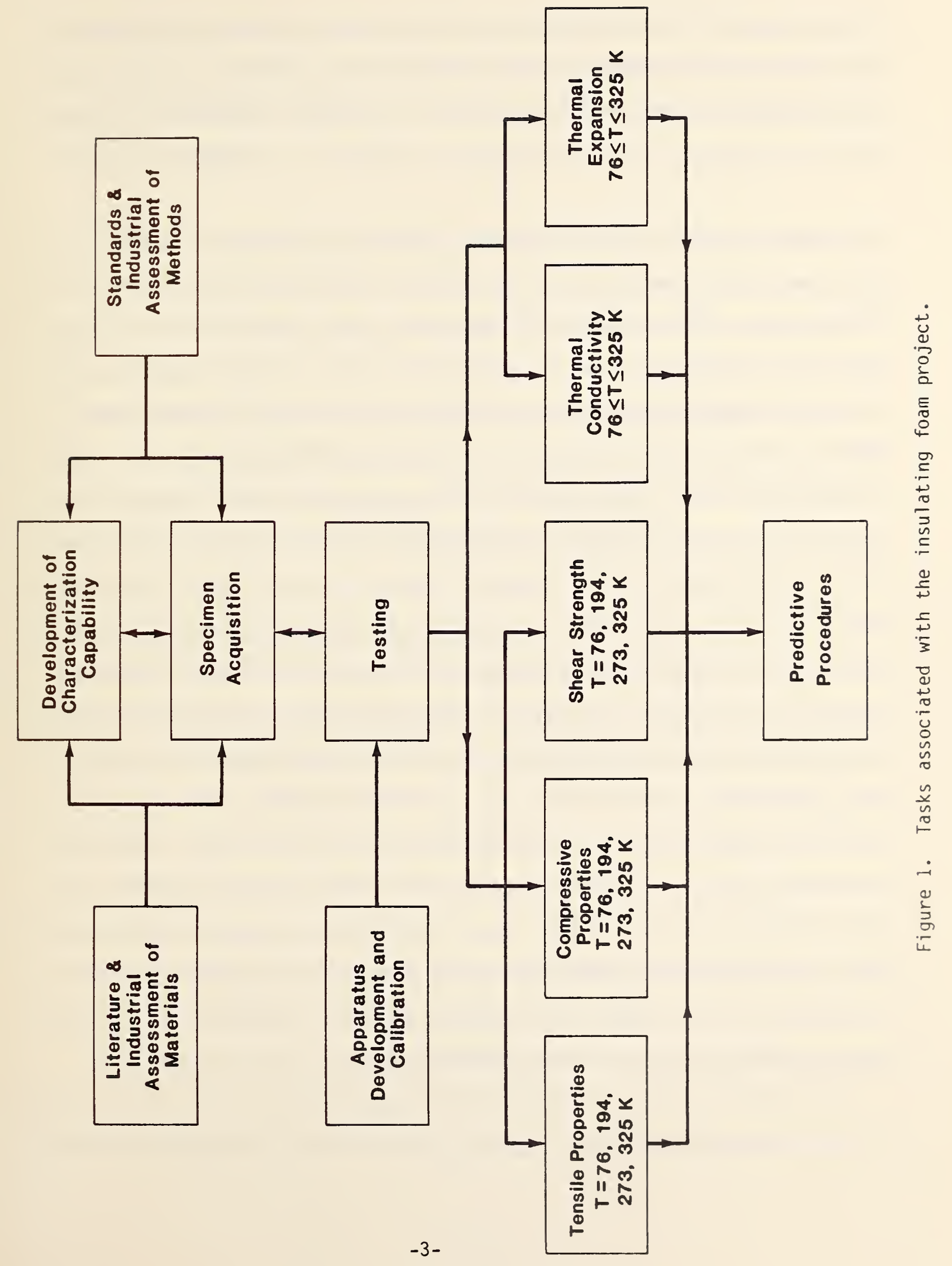


for expanded plastics at low temperatures. This task, therefore, necessarily involved evaluation of apparatuses and procedures used at NBS and in industry. Special apparatuses were ultimately required for adequate testing of thermal expansion and mechanical properties of these viscoelastic, anisotropic materials.

(3) Characterization - The development of predictive techniques for foam properties requires knowledge of morphology, cell gas, and chemical composition of the test specimens. Several methods of determining these parameters were evaluated during the course of the project. The criteria used in determining the final role of the various techniques was quality and usefulness of the output and whether or not the procedure could be reasonably applied by producers and users of polyurethane foams. The following procedures were evaluated: (a) Gas chromatograph/mass spectrometer - used to determine the composition of the gases present in the foam cells. (b) Scanning electron microscopy (SEM) - reflected beams of electrons produce photographs with depth of field much superior to optical photographs. (c) Photomicrography - an optical microscope designed specifically to observe grain structure in metals was used to study the cell structure of the $32-\mathrm{kg} / \mathrm{m}^{3}$ foam. (d) Polarized photomicrographs-polarized light enhances resolution of cell structure and was used to study the cell structure of the $64-$ and $96-\mathrm{kg} / \mathrm{m}^{3}$ foams. (e) Thermogravimetric analysis (TGA) - used to determine mass loss as a function of temperature. The results were used to identify constituent material's in the foams. (f) Differential scanning calorimetry (DSC) - used to determine heat capacity as a function of temperature. Temperature dependent phase changes can be detected using this technique. (g) Gas comparison pycnometry - used to study foam morphology. 
(4) Specimen Acquisition - Bulk supplies of $32-$ and $64-\mathrm{kg} / \mathrm{m}^{3}$ specimens were obtained from the Products Research Committee (1980) through the Office of Standard Reference Materials of NBS. The $96-\mathrm{kg} / \mathrm{m}^{3}$ material was purchased from a cormercial producer.

(5) Testing - Several basic properties were considered to be essential to the use of insulating foams in the LNG industry. In addition to the characterization tests, the following types of data were obtained for each of the three polyurethane specimens: thermal conductivity, thermal expansion, coefficient of thermal expansion, tensile, shear, and compressive strengths, Young's modulus, proportional limit, yield strength at $0.2 \%$ offset, and elastic and plastic elongation. The temperature range of study always included 100 to $300 \mathrm{~K}$, and in several instances, data were obtained from considerably outside this range.

\section{Project Rationale and Projected Benefits (IF)}

Expanded polyurethanes are complicated composite materials. The values of most thermophysical properties depend on the direction of heat flow or stress application relative to the direction of free foam expansion during polymerization. Aging affects the properties both due to gas diffusion and to resin changes. The net result is that current use of insulating foams in cryogenic applications involves costly overdesign and, in some instances, undesirable results. Much of the existing low temperature data for foams is based on uncharacterized materials and were determined with experimental methods unsuited for low temperature testing.

The rationale for the study of insulating foams was to al leviate the problems currently faced by designers of foam insulation systems. The three-fold thrust to accomplish this was: (1) to generate reliable low temperature data for 
three polyurethane foams whose densities span the range of practical insulating foams; (2) to utilize these data to develop predictive procedures for low temperature properties; and (3) to establish a direction for further low temperature research on expanded plastics. Important complimentary research includes examination of test procedures and design of special equipment to study foam-like materials. Also, the possibility of developing a foam standard reference material needed to be examined.

The benefits of items (1) and (2) above are clear and immediate. The data. can be used as an engineering guide for initial design of polyurethane insulation systems. The predictive procedures can be used to further refine expected behavior when used in conjunction with specific foam characteristics. The highest quality design data for a specific foam must be based on information about the particular foam formulation and on an understanding of the effect of different foam characteristics on the low temperature properties. In order for this to be done in a practical way, standardized tests and materials must be readily available. Ultimately, the economic and safe utilization of these insulating materials in LNG applications depends on further research to bring expanded plastics to the level of development of other materials used in LNG facilities.

\section{TECHNICAL DISCUSSION (IF)}

Work Plan (IF)

The work $\mathrm{plan}$ for the duration of the foam study followed the general steps outlined in the Project Description section. The early stage of the work was devoted to selecting the most useful type of insulation for LNG applications and to determine what, if any, standard procedures existed to allow reliable low temperature data to be generated. A significant literature search had been done and industrial contacts were already established for an earlier project. Evaluation 
of data and procedures indicated that most materials tested previously could not be identified well enough to be of use in developing predictive procedures and that the only standard procedure that could be readily applied at cryogenic temperatures waS ASTM C177 for thermal conductivity. Two experimental systems suited to testing viscoelastic anisotropic foams were near completion at NBS. Characterization of the foams presented another obstacle. The literature and fundamental parameters in thermophysical properties suggested that the morphology of a foam and the statistical size, shape, and orientation of the cells was of primary importance. Several papers dealing with measurement techniques and interpretation (Smith and Guttman, 1953; Harding, 1960; Schael, 1967; and Thompson, 1972) were evaluated and utilized, in part, to characterize the polyurethane specimens.

A large number of procedures for determining various attributes of the materials were evaluated. The primary characterization effort centered on determining the cellular structure optically and determining the cellular gas content using a gas chromatograph backed by a mass spectrometer. An important consideration in both testing and characterization was that the procedures be such that they could be adopted for general use. This is particularly important for characterization of foams: predictive procedures will be more useful if the parameters can be determined with reasonable effort.

After proving the experimental systems and acquiring and characterizing the specimens, the following thermophysical properties were determined for each of the three polyurethane foams: thermal conductivity, thermal expansion, tensile, shear, and compressive strengths, Young's modulus, proportional limit, yield strength at $0.2 \%$ offset, and elastic and plastic elongation. The results of the testing program were to be assessed for the possibility of describing the measured values with analytical models. 
The nominal densities of the polyurethane foam specimens were 32,64 , and $96 \mathrm{~kg} / \mathrm{m}^{3}$ (PU32, PU64, and PU96). PU32 and PU64 were obtained from the NBS Office of Standard Reference Materials (OSRM), Washington, D.C. The OSRM distributed these and other expanded plastics for the Products Research Committee (1980). These materials were comnercially produced and distributed by OSRM as General Materials. The third material, PU96, was purchased from a commercial manufacturer, since OSRM did not stock a General Material in this density range. The bulk supplies of these materials were in the forms shown in figure 2 . The coordinate axes assigned to the bulk materials are indicated in this figure. The thermal expansion, thermal conductivity, and longitudinal mechanical property measurements were made parallel to the z-axis. The transverse mechanical properties were measured parallel to the $y$-axis.

Densities - The densities of the bulk supplies were determined for four specimens of each material. After conditioning at $23{ }^{\circ} \mathrm{C}$ and $50 \%$ relative humidity, the densities were found to be $33.56 \pm 0.14,62.52 \pm 0.11$, and 99.03 $\pm 3.4 \mathrm{~kg} / \mathrm{m}^{3}$. The uncertainties represent estimates of one standard deviation. The large uncertainty in the PU96 density results from a density variation in the bulk supply.

Optical characterization - Optical characterization involved three general procedures: (1) examination of the bulk supplies by means of a binocular microscope with an extension arm, (2) maximum-cell-dimension analysis of polarized photomicrographs of the principal orthogonal planes, $X Y, X Z, Y Z$ in (fig. 3), and (3) analysis of cell-wall intercepts at $30^{\circ}$ rotations for the $p l a n e s ~ X Y, X Z$, and YZ (fig. 3).

Bulk examination - This examination was intended to reveal the existence of nonvertical flow lines, i.e., foam rise directions not parallel to the z-axis. 


\section{Thermal Conductivity}

Mechanical Properties

Thermal Expansion

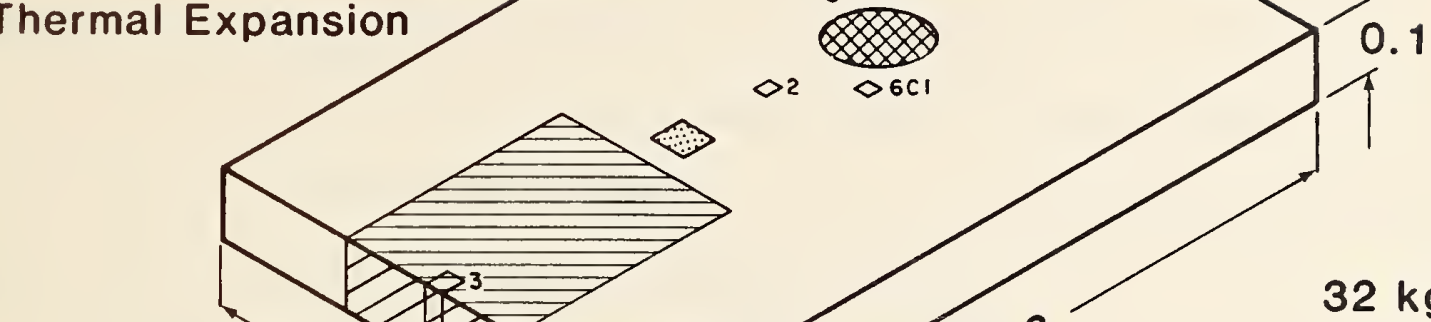

$32 \mathrm{~kg} / \mathrm{m}^{3}$

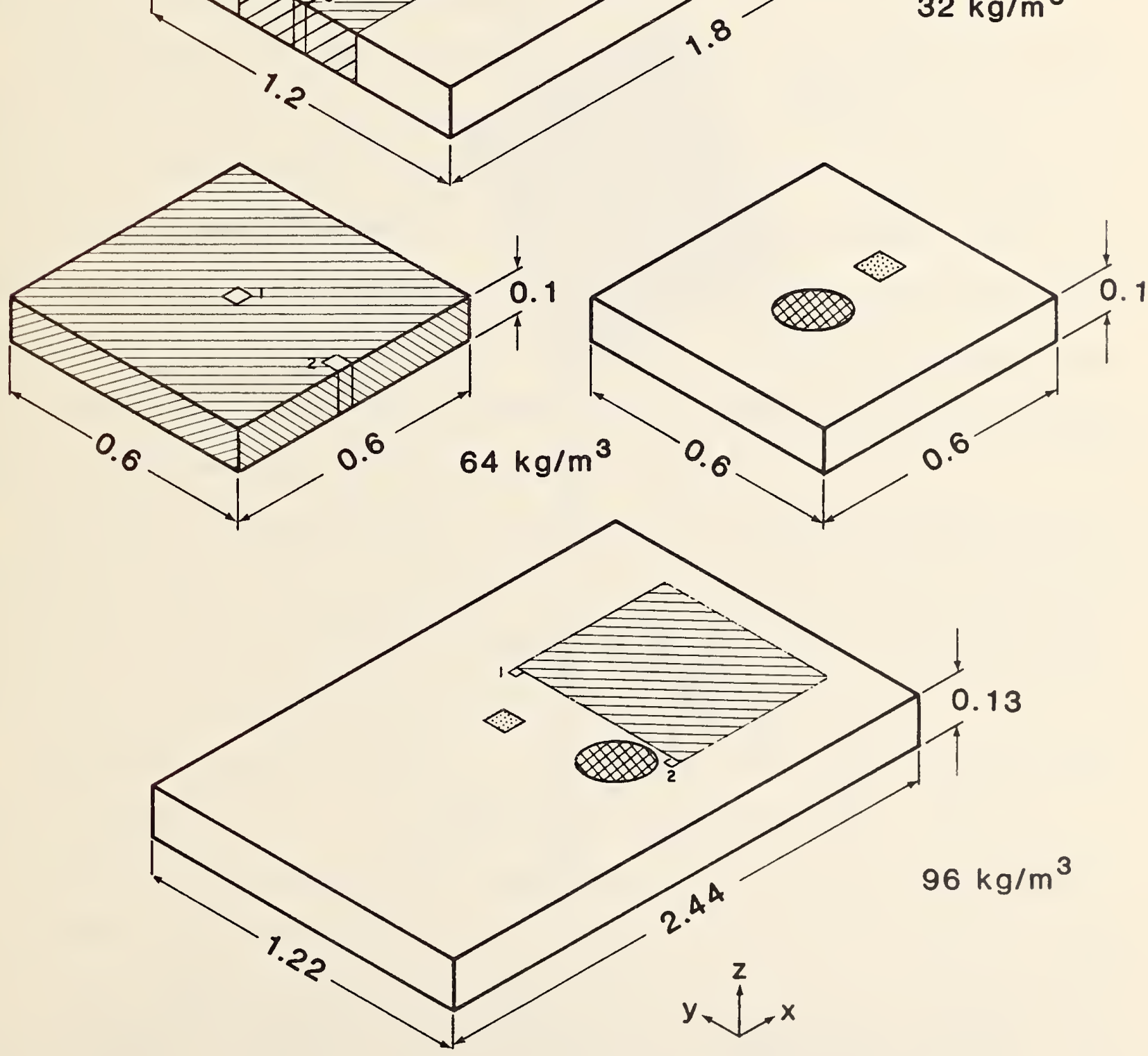

All dimensions in meters.

Figure 2. Bulk supplies of polyurethane foam and orientation of axes. Numbered rectangles indicate areas used for characterization. 


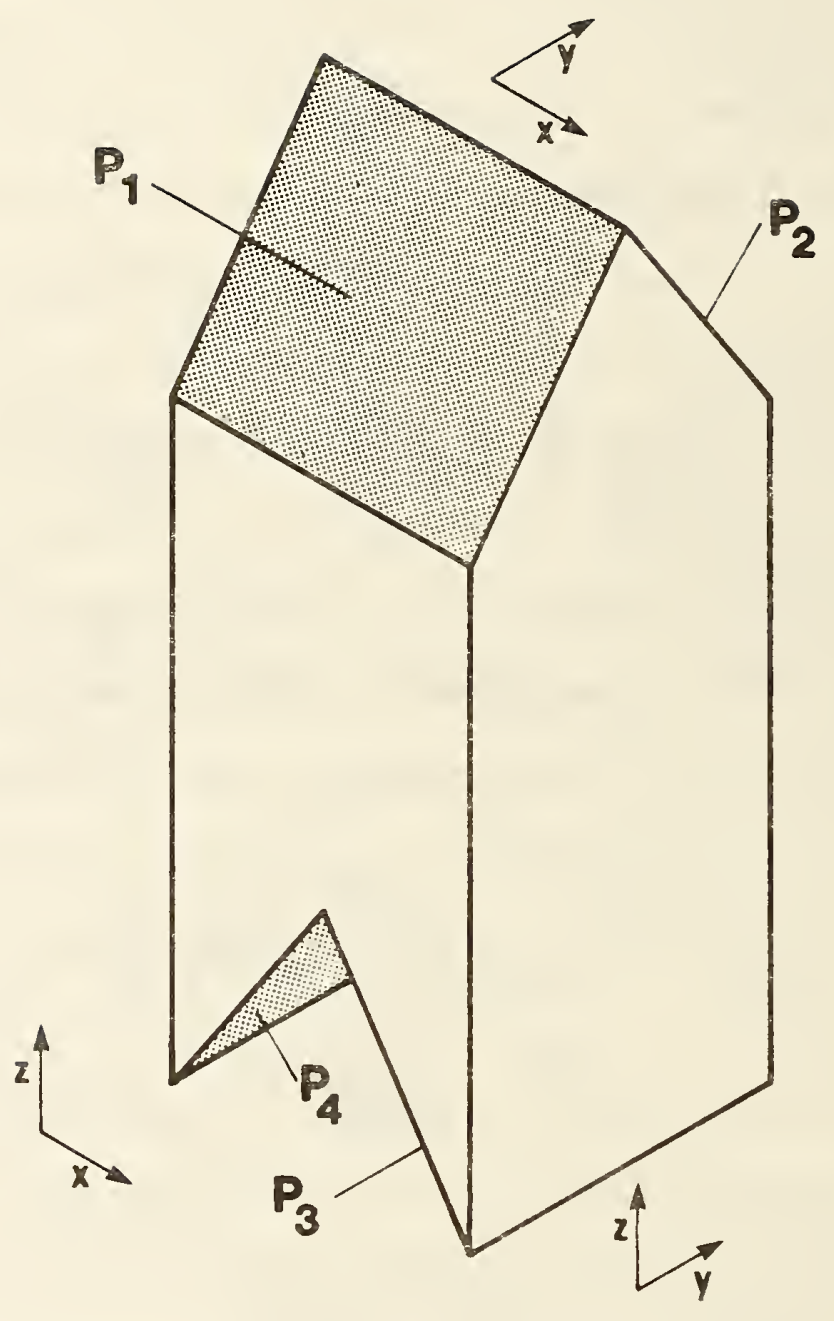

Figure 3. Configuration of the planes studied by optical methods. 
This type of examination of PU32 indicated that the elongated cell axes were not vertical at any place in the bulk supply, and that the cells near the long edges (approximately $0.3 \mathrm{~m}$ in from each long edge) were inclined about $35^{\circ}$ in the $X Y$ plane, $45^{\circ}$ in the $X Z$ plane, and $55^{\circ}$ in the $Y Z$ plane (fig. 4). Cells in the center portion had $0^{\circ}$ inclination in the $X Y$ and $Y Z$ planes, but retained the $45^{\circ}$ inclination in the $X Z$ plane. These qualitative assessments were confirmed in the quantitative intercept analysis discussed below.

The bulk supply of PU64 consisted of three slabs. Nonvertical flow lines were observed in each of the pieces but the angle of inclination was smaller than that found in PU32. The cellular inclinations of two of the three slabs were consistent and identical within the uncertainty of the measurements (fig. 4 ). The inclinations found in the third slab were not uniform, i.e., the inclination was significantly different for parallel planes. No additional tests were performed on this slab. The slab designated PU64-1 was used for mechanical property tests and PU64-3 was used for thermal property tests.

Non-vertical alignment of the long cellular axes of PU96 was found only in an $0.08 \mathrm{~m}$ thickness around the perimeter. A $0.2 \mathrm{~m}$ thickness around the perimeter was marked as scrap, and no test specimens were taken from this material. The cellular orientation for all planes of PU96 are shown in figure 4 .

Maximum-cell-dimension analysis - This procedure was used to determine the ratios of maximum cellular dimensions parallel to the major axes. Microscope slides were made by passing a blade through the foam at a given orientation. This procedure was done with the cutting planes parallel to the principal planes: $X Y, X Z, Y Z$. Photomicrographs were prepared with a minimum of two different sections per plane for each foam. It was found that a magnification of 50 was suitable and that the contrast achieved using incident, polarized light produced clearly defined cell boundaries. Maximum cell dimensions parallel to the 


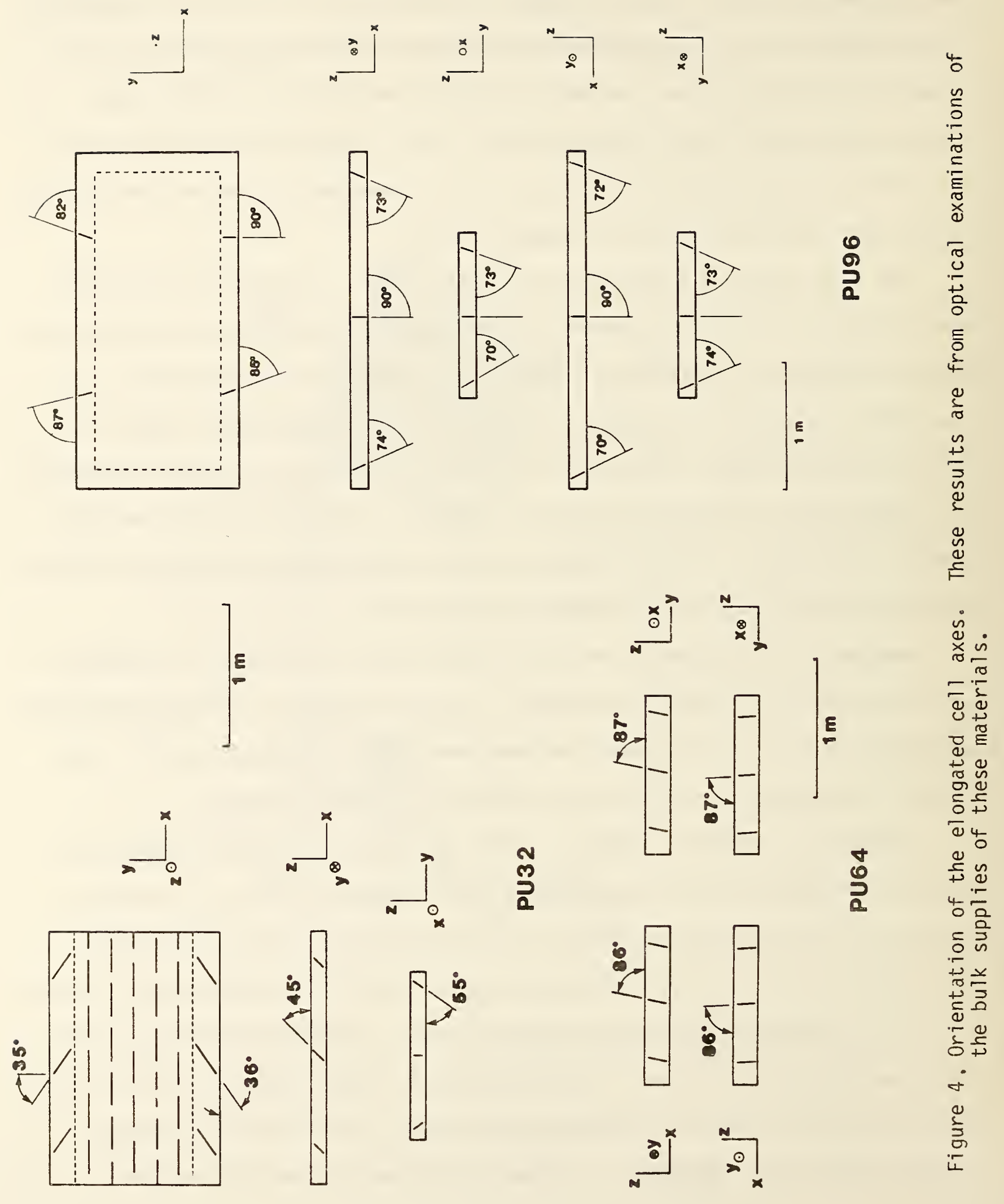


principal axes were determined from the length calibrated photographs. Results of these measurements are given in table 1 . The lengths measured and presented

Table 1. Maximum intercepted cell dimensions parallel to the orthogonal principal axes of the $X Y, X Z$, and $Y Z$ planes for four specimens of PU32 and two specimens each of PU64 and PU96. Locations of the specimens are indicated in figure 2.

\begin{tabular}{cccc} 
Specimen & $\begin{array}{c}\text { X Axis } \\
(\mu \mathrm{m})\end{array}$ & $\begin{array}{c}Y \text { Axis } \\
(\mu \mathrm{m})\end{array}$ & $\begin{array}{c}Z \text { Axis } \\
(\mu \mathrm{m})\end{array}$ \\
\hline PU32-2 & 527 & 406 & 488 \\
PU32-3 & 492 & 380 & 510 \\
PU32-6C1 & 482 & 356 & 458 \\
PU32-6C2 & 461 & 364 & 457 \\
PU32-average & 490 & 376 & 478 \\
\hline PU64-1 & 213 & 218 & 348 \\
PU64-2 & 208 & 221 & 333 \\
PU64-average & 210 & 220 & 340 \\
\hline PU96-1 & 272 & 240 & 257 \\
PU96-2 & 226 & 250 & 300 \\
PU96-average & 249 & 245 & 278 \\
\hline
\end{tabular}

in this table represent the maximum intercepted dimension which is somewhat smaller than the actual maximum cell dimension. Several authors (Hensler, 1968; Exner, 1969; and Thompson, 1972) have proposed multiplicative factors needed to arrive at actual maximum cell dimensions from maximum intercepted cell dimensions." These factors range from 1.5 to 1.68 with the differences being due to assumptions about cell shape and packing factors. The ratios given in table 2 eliminate this source of uncertainty.

Intercept analysis - The procedure used to arrive at these data also utilizes photographs of foam cells and follows the acquisition scheme suggested by Smith and Guttman, 1953. This approach assumes randomly oriented sections. 
Table 2. Ratios of averaged maximum intercepted cell dimensions paral lel to the orthogonal principal axes of the $X Y, X Z$, and $Y Z$ planes for four specimens of PU32 and two specimens each of PU64 and PU96. Locations of the specimens are indicated in figure 2.

\begin{tabular}{cccc} 
Specimen & $Z / X$ & $Z / Y$ & $X / Y$ \\
\hline PU32-average & 0.98 & 1.27 & 1.30 \\
PU64-average & 1.62 & 1.55 & 0.95 \\
PU96-average & 1.12 & 1.13 & 1.02 \\
\hline
\end{tabular}

Randomness was approximated by seven $\mathrm{planes,} X Y, X Z, Y Z$ and $p l$ anes $P_{1}$ through $\mathrm{P}_{4}$ in figure 3 , for each of two locations per material, i.e., 14 photographs for each of the three polyurethane foams. Each photograph was evaluated by superimposing a grid of parallel lines and counting the intersections of grid lines and cell walls. Data were taken for grid rotations of $0,30,60$, and 90 degrees. Statistical evaluation of these data, as suggested by Schael, 1967, results in the cross-sectional areas listed in table 3 . The quality of these data depend strongly on how nearly the sampling procedure produces a random cross section of the foam. If randomness is assumed, these data are independent of cell shape.

Gas comparison pycnometry - Acquisition of cellular data by optical means is tedious and its interpretation is time consuming. Gas comparison pycnometry (GCP), as discussed by Harding (1960), Rice and Nunez (1962), and Schael (1967), can theoretically be used to obtain similar data more rapidly. This technique requires only commercially available equipment and, after adopting an appropriate experimental procedure, could be done on a routine basis.

The principle of GCP operation is Boyle's law: the product of pressure and volume of an ideal gas is constant at a given temperature. The quantity actually determined is specimen volume as measured by gas displacement, i.e., volume of foam as determined by GCP would be smaller than the physical dimensions of the 
Table 3. Intercepted cell section area computed from cell wall intercept data for two specimens each of PU32, PU64, and PU96. The method of computation follows that described by Schael (1967). Locations of the specimens are indicated in figure 2.

\begin{tabular}{|c|c|c|c|}
\hline Specimen & $\begin{array}{c}\mathrm{XY}{ }_{2} \mathrm{Pl} \text { ane } \\
\left(\mathrm{cm}^{2} / \mathrm{cell}\right)\end{array}$ & $\begin{array}{c}\mathrm{XZ}_{2} \mathrm{Pl} \text { ane } \\
\left(\mathrm{cm}^{2} / \mathrm{cell}\right)\end{array}$ & $\begin{array}{c}\mathrm{YZ}_{2} \mathrm{Pl} \text { ane } \\
\left(\mathrm{cm}^{2} / \mathrm{cell}\right)\end{array}$ \\
\hline PU32-2 & $1.27 \times 10^{-3}$ & $1.21 \times 10^{-3}$ & $1.25 \times 10^{-3}$ \\
\hline PU32-3 & $1.02 \times 10^{-3}$ & $1.32 \times 10^{-3}$ & $1.11 \times 10^{-3}$ \\
\hline PU32-average & $1.15 \times 10^{-3}$ & $1.27 \times 10^{-3}$ & $1.18 \times 10^{-3}$ \\
\hline PU64-1 & $2.90 \times 10^{-4}$ & $4.23 \times 10^{-4}$ & $4.59 \times 10^{-4}$ \\
\hline PU64-2 & $2.59 \times 10^{-4}$ & $4.19 \times 10^{-4}$ & $4.83 \times 10^{-4}$ \\
\hline PU64-average & $2.75 \times 10^{-4}$ & $4.21 \times 10^{-4}$ & $4.71 \times 10^{-4}$ \\
\hline PU96-1 & $5.51 \times 10^{-4}$ & $5.53 \times 10^{-4}$ & $4.69 \times 10^{-4}$ \\
\hline PU96-2 & $4.74 \times 10^{-4}$ & $4.69 \times 10^{-4}$ & $5.88 \times 10^{-4}$ \\
\hline PU96-average & $5.13 \times 10^{-4}$ & $5.11 \times 10^{-4}$ & $5.29 \times 10^{-4}$ \\
\hline
\end{tabular}

specimen would indicate because of open cells. By sectioning a foam specimen in a particular sequence and making multiple determinations of the resulting specimen GCP volumes, information on open cell content, cell size, and axial dimensions can be calculated. Several GCP operating procedures were evaluated. The procedure selected for use involved subjecting the test specimens to a pressure variation from 0.4 to $200 \mathrm{kPa}$ of nitrogen gas. An individual GCP test required only minutes to complete so that diffusion of gas and concomitant changes in internal pressure were assumed to be negligible. Results of the GCP analysis and a comparison to optically obtained values are given in table 4.

The optical data are internally consistent, i.e., if elliptical cross sections are assumed, the axial dimensions can be used to compute the cellular cross sectional area to within the uncertainty of the data. This is not true for the GCP data for either the cellular volume of cross section. However, as will be 
Table 4. Results of gas comparison pycnometer (GCP) characterization of PU32, PU64, and PU96. Comparable results from optical evaluations of the same materials are also given.

Parameter

Average Cell Volume, $10^{-5} \mathrm{~cm}^{3}$
PU32

$\begin{array}{lll}11.7 & 5.76 \quad 4.06\end{array}$

PU64

GPC Optical

\section{PU96}

Optical

4.05

Fraction Open Cells, \%

$\begin{array}{llll}P 1 \text { ane } X Y & 5.9 & 0.9 & 2.4 \\ \text { Plane XZ } & 6.3 & 3.4 & 5.0 \\ \text { Plane YZ } & 3.4 & 4.0 & 4.0\end{array}$

Cellular Cross-Section, $10^{-3} \mathrm{~cm}^{2}$

$\begin{array}{lllllll}\text { Plane XY } & & & \\ \text { Plane XZ } & 4.75 & 1.15 & 1.40 & 0.275 & 1.55 & 0.513 \\ \text { Plane YZ } & 5.06 & 1.27 & 2.25 & 0.421 & 2.67 & 0.511 \\ & 3.24 & 1.18 & 2.59 & 0.471 & 2.10 & 0.529\end{array}$

Axial Dimensions, $\mu \mathrm{m}$
$X$ Axis
$Y$ Axis
$Z$ Axis

$\begin{array}{ll}247 & 490 \\ 224 & 376 \\ 338 & 478\end{array}$

123

142

227

\section{0}

153

120

249

220

207

245

278

Axial Ratios

$\begin{array}{lllllll}Z / X & 1.37 & 0.98 & 1.85 & 1.62 & 1.35 & 1.12 \\ Z / Y & 1.51 & 1.27 & 1.60 & 1.55 & 1.72 & 1.13 \\ X / Y & 1.10 & 1.30 & 0.87 & 0.95 & 1.28 & 1.02\end{array}$

seen later, the essential quantities in the predictive procedures are the axial ratios. These ratios, computed using GCP and optical data, are in reasonable agreement.

Cell-gas analysis - An important component of thermal conductivity of closed-cell foams is gas conduction. The composition of the gas in the cells was determined in order to allow this component of the apparent conductivity to be assessed. Gas samples were obtained using the system shown in figure 5 . The procedure was as follows: (1) A $3.5 \mathrm{~cm}^{3}$ specimen was placed in the crushing device (fig. 5b) and sealed using an indium ring. (2) The crusher was attached to the purge system (fig. 5a). (3) System pressure was reduced to $50 \mathrm{kPa} a b-$ solute followed by a helium-gas backfill to $115 \mathrm{kPa}$. This step was repeated 20 


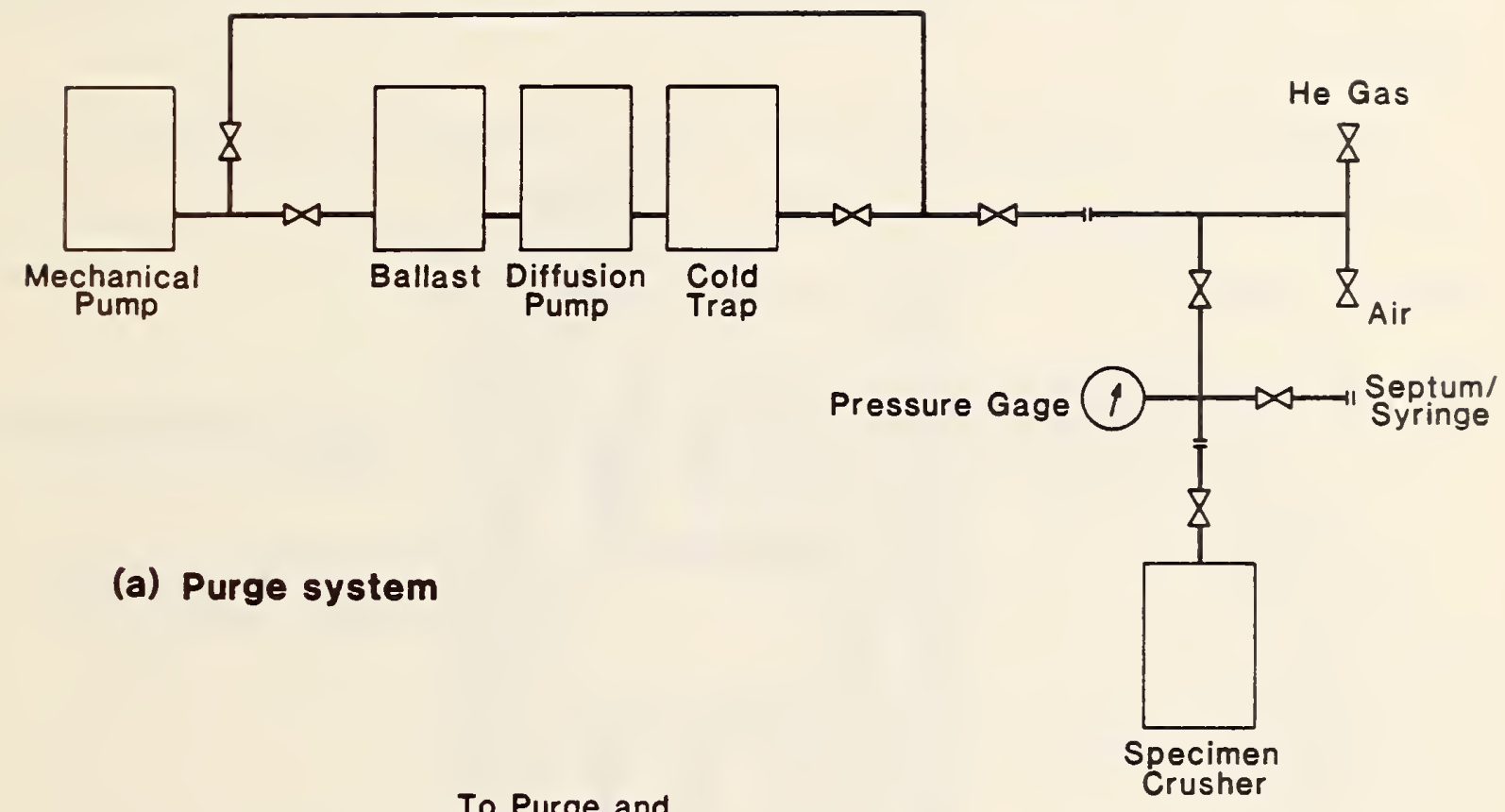

To Purge and

Sampling Port

(b) Foam crushing device

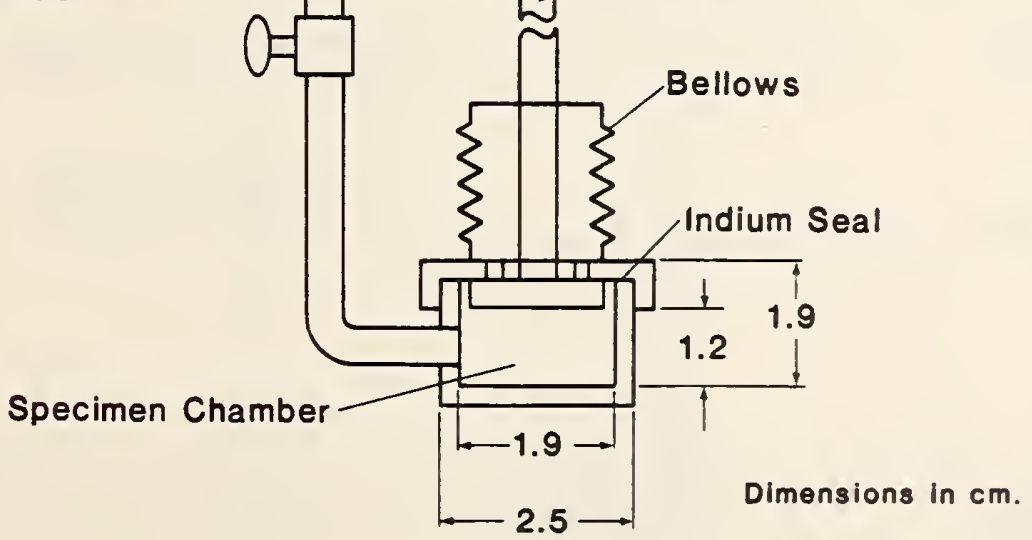

Figure 5. Schematic of the system used to obtain samples of cell yas from fluorocarbon blown polyurethane foams. 
times and resulted in an air content, external to the foam, of $1 \mathrm{ppm}$. (4) Crusher and foam were cooled to liquid nitrogen temperature and the plunger depressed. The brittle foam specimens were reduced to a compacted powder assuring that essentially all cells had been fractured. (5) A gas specimen was drawn into a gas-tight syringe and inserted into the analysis system. Steps (1) through (5) were repeated on four specimens from each of the three polyurethane foams.

The analysis system consisted of a gas chromatograph column with a massspectrometer detector (Barkley, 1983). The averaged results of the analysis are shown in täble 5 .

Table 5. Cell-gas composition of PU32, PU64, and PU96 (Barkley, 1983). One standard deviation for the $\mathrm{CC}_{3} \mathrm{~F}$ contents is $\pm 10 \%$.

\begin{tabular}{cccc} 
& \multicolumn{3}{c}{ Mole $\%$} \\
\cline { 2 - 4 } Specimen & CC ${ }_{3} F$ & $0_{2}$ & $N_{2}$ \\
\hline PU32-1 & 93.6 & 2.2 & 4.2 \\
PU32 -2 & 93.6 & 2.2 & 4.2 \\
PU32-3 & 94.7 & 2.0 & 3.4 \\
PU32-4 & 90.6 & 4.0 & 5.4 \\
PU32-average & 93.1 & 2.6 & 4.3 \\
\hline PU64-1 & 92.8 & 2.8 & 4.4 \\
PU64-2 & 91.8 & 3.3 & 4.9 \\
PU64-3 & 83.0 & 5.4 & 11.6 \\
PU64-4 & 93.6 & 2.2 & 4.2 \\
PU64-average & 90.3 & 3.4 & 6.3 \\
\hline PU96-1 & 87.0 & 2.0 & 10.5 \\
PU96-2 & 95.2 & 1.0 & 4.5 \\
PU96-3 & 94.2 & 2.4 & 3.0 \\
PU96-4 & 96.2 & 0.4 & 2.9 \\
PU96-average & 93.2 & 1.5 & 5.2 \\
\hline
\end{tabular}

Thermal conductivity - The apparatus used to make the thermal conductivity (k) measurements is shown schernatically in figures 6 and 7 . The path of the 


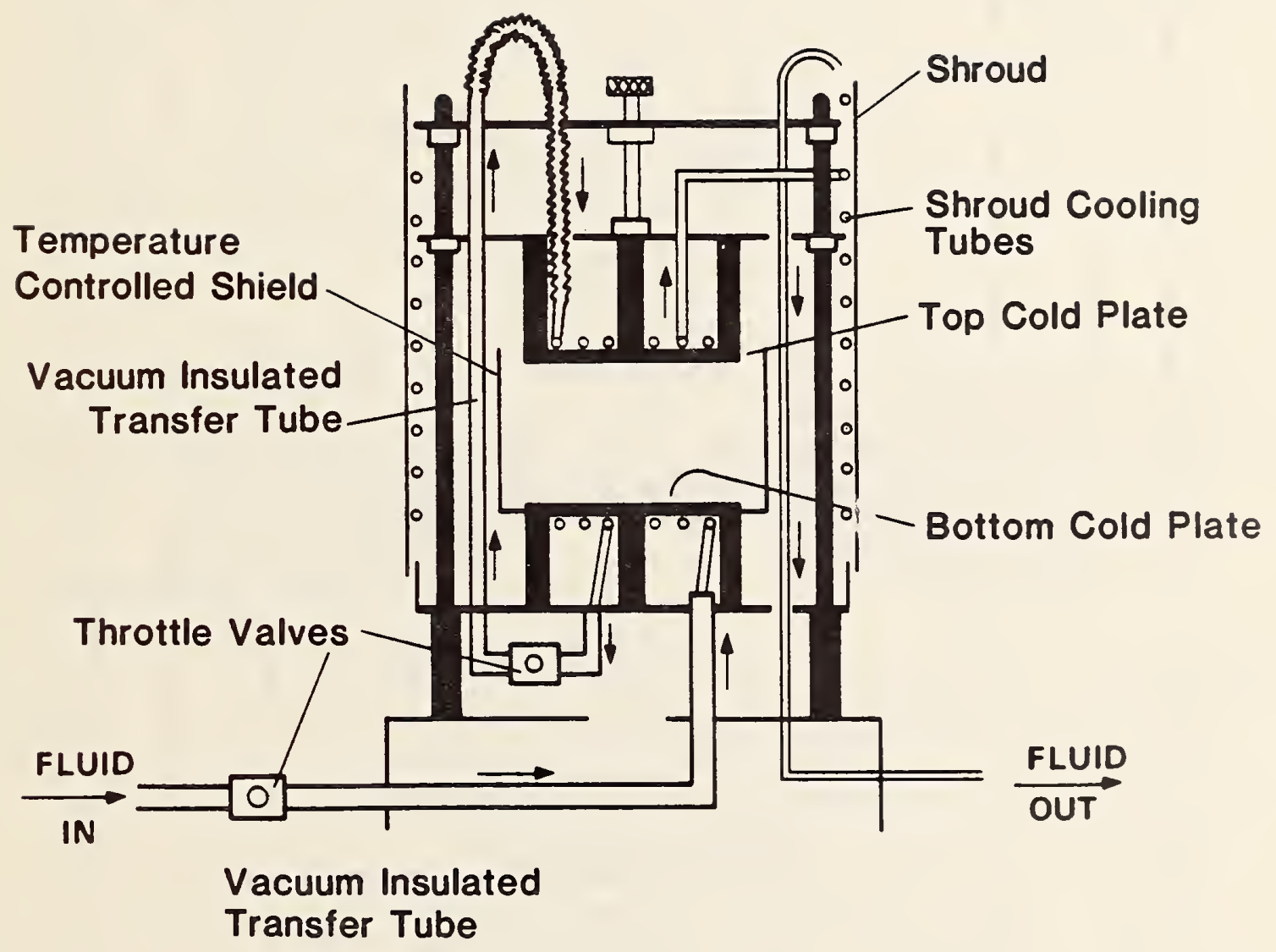

Figure 6. Schematic of the guarded-hot-plate thermal conductivity apparatus. 


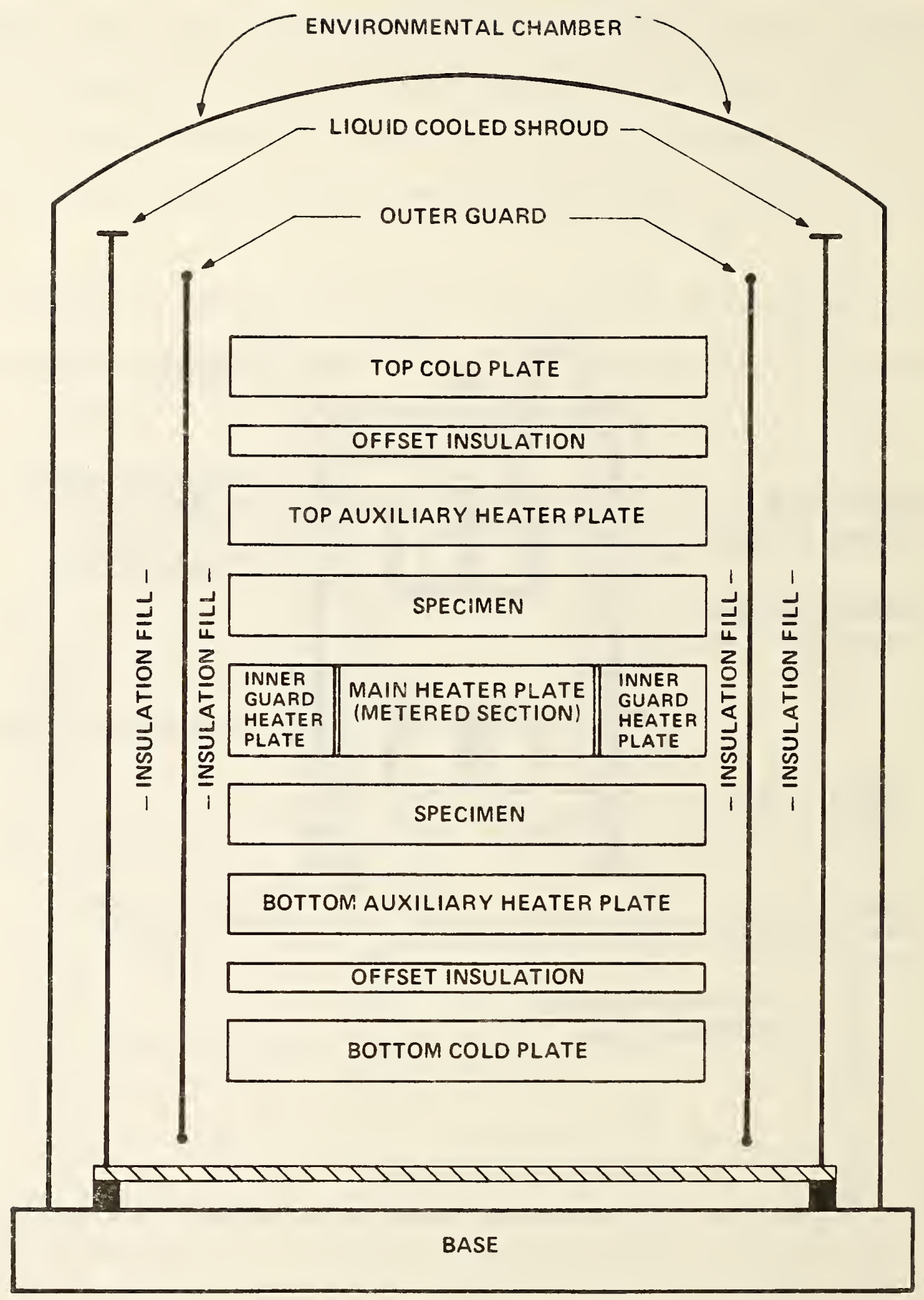

Figure 7. Schematic of guarded-hot-plate specimen configuration and environmental chamber 
cooling fluid is shown in figure 6 and the details of the specimen configuration are shown in figure 7. This type of system is commonly known as a guarded-hotplate and is described in the American Society for Testing and Materials Standard C177 (ASTM, C177). This method allows an absolute determination of $k$ and is considered to be the most accurate method available for insulations. The particular apparatus used to make the $k$ measurements reported here is described by Smith, Hust, and Van Poolen (1981); a very brief description is included below.

The basic operation of this type of apparatus involves supplying a measured amount of power, Q, from the main heater plate to the two specimens (fig. 7) and measuring the resulting steady-state temperature differences across the specimens. The thermal conductivity is then given by

$$
k=\frac{\Delta X}{2 A} \cdot \frac{Q}{\Delta T}
$$

where $\Delta X$ is the sample thickness, $A$ is the area of the metered section of the main heater plate, and $\Delta T$ is the steady-state mean temperature difference across the specimeris. The absolute temperatures and temperature differences are measured with type $K$ thermocouples.

The accuracy of the $k$ results is dependent on the accuracy of measurement of the parameters shown in eq (1) and on establishment of unidirectional (vertical in this case) heat flow in the metered area of the specimens. The inner-guard heater plate is controlled at the temperature of the main heater in order to minimize radial heat flow in the metered area. Somers and Cyphers (1951) and ASTM C177 indicate that when the diameter-to-thickness ratio of a specimen is greater than four, the errors in $k$ due to edge losses should be less than $1 \%$. The metered diameter of the foam specimens was $10.2 \mathrm{~cm}$ and the thickness was $2.54 \mathrm{~cm}$.

The most difficult parameter to determine is the specimen temperature difference $(\Delta T) ; \Delta T$ averaged $10 \mathrm{~K}$ for PU32 and $25 \mathrm{~K}$ for PU64 and PU95. The 
correctness of $\Delta T$ measurements depends on plate-to-specimen thermal contact, on unidirectional heat flow, and on thermocouple calibration and referencing sources of error. The diverse materials which can be tested in this type of system cause a wide range of plate-to-specimen contact situations. Tye and Spinney (1976) found that embedding the thermocouple wires in the specimen, as opposed to the measuring plates, resulted in higher calculated conductivities. This effect is due to better specimen-to-thermocouple contact which results in smaller measured $\Delta T$ and larger $k$ (eq (1)). They al so found that the effect of thermocouple placement was dependent on the conductivity of the specimens. As the conductivity of the specimen increases, the relative effect of an air gap in the specimen-toplate interface becomes larger.

Thermocouple placement used in obtaining the data reported below consisted of cementing the wires into machined grooves in the measuring plates (plates adjacent to the specimens shown in figure 7) so that the thermocouples were flush with the plate surfaces.

The accuracy of measurements made with this system on fiberglass and fiberboard reference materials is discussed by Smith, Hust, and Van Poolen (1981). In a qualitative sense the plate-to-specimen contact should be similar for lowdensity foams and the fiberous materials tested by Smith, et al. Based on the percentage errors given by Smith, et al. for each parameter in eq (1) and the magnitude of these parameters for the PU foam experiments, uncertainties in the PU foam data ( $\mathrm{K}$ ) are estimated to be $0.2 \mathrm{~mW} / \mathrm{m} \cdot \mathrm{K}$ random and $0.4 \mathrm{~mW} / \mathrm{m} \cdot \mathrm{K}$ systematic near room temperature; near $80 \mathrm{~K}$ the random and systematic components are $0.1 \mathrm{mK} / \mathrm{m} \cdot \mathrm{K}$.

The specimen environment throughout the testing period was dry-nitrogen gas. The gas surrounding the specimen was maintained at a slight positive pressure of 260 to $660 \mathrm{~Pa}(2$ to $5 \mathrm{~mm} \mathrm{Hg}$ ) relative to atmospheric pressure. The plate emittance was 0.82 . 
Thermal conductivity as a function of temperature is shown in tables 5 and 7 and in figure 8. Each number given in tables 6 and 7 represents an average of three or more determinations of $k(T)$; the determinations were separated by a minimum of 15 minutes.

Table 6. Average thermal conductivity as a function of average temperature for a $32-\mathrm{kg} / \mathrm{m}^{3}$ polyurethane foam.

\begin{tabular}{rccc}
\hline $\begin{array}{c}T \\
(\mathrm{~K})\end{array}$ & $\begin{array}{c}\mathrm{k} \\
(\mathrm{m} / \mathrm{m} \cdot \mathrm{K})\end{array}$ & $\begin{array}{c}T \\
(\mathrm{~K})\end{array}$ & $\begin{array}{c}\mathrm{k} \\
(\mathrm{m} / \mathrm{m} \cdot \mathrm{K})\end{array}$ \\
\hline 95.10 & 11.4 & 256.76 & 22.6 \\
106.89 & 13.0 & 258.17 & 22.8 \\
120.39 & 14.6 & 264.67 & 21.6 \\
132.04 & 15.8 & 270.65 & 20.4 \\
153.89 & 18.2 & 274.67 & 20.1 \\
169.54 & 19.9 & 275.74 & 19.9 \\
175.29 & 20.7 & 280.78 & 20.0 \\
185.78 & 21.7 & 284.90 & 20.5 \\
202.20 & 23.1 & 290.79 & 21.2 \\
214.63 & 23.8 & 297.00 & 21.6 \\
216.82 & 23.8 & 297.95 & 21.8 \\
220.54 & 23.9 & 301.97 & 22.2 \\
239.67 & 23.8 & 318.03 & 24.5 \\
239.91 & 23.8 & 332.38 & 26.2 \\
248.97 & 23.6 & 332.94 & 26.0 \\
& & 340.22 & 27.8 \\
\hline
\end{tabular}




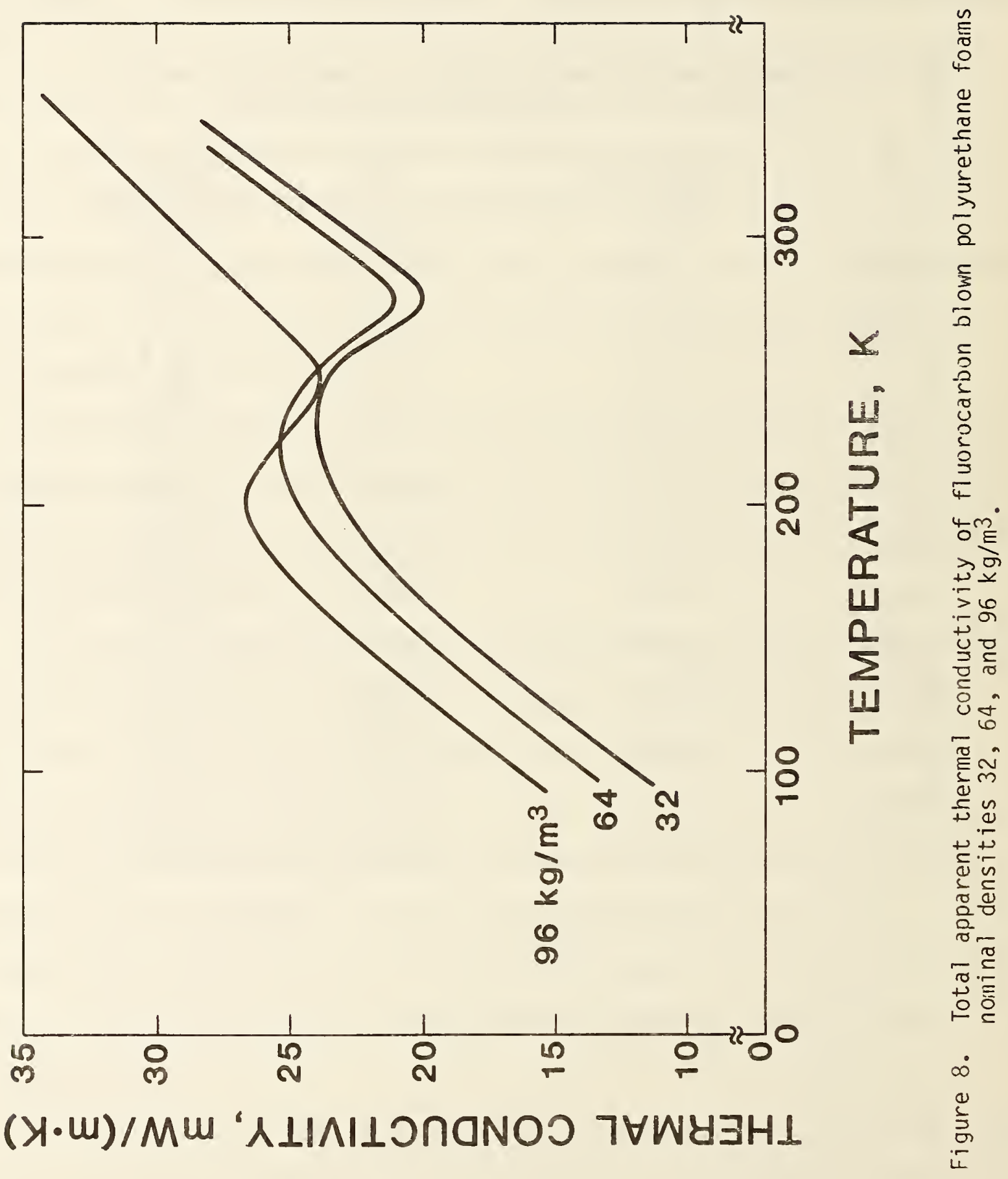


Table 7. Average thermal conductivity as a function of average temperature for $64-$ and $96-\mathrm{kg} / \mathrm{m}^{3}$ polyurethane foams.

\begin{tabular}{rccc}
\multicolumn{2}{c}{$64-\mathrm{kg} / \mathrm{m}^{3}$} & specimen & \multicolumn{2}{c}{$96-\mathrm{kg} / \mathrm{m}^{3}$} & specimen \\
\hline$T(\mathrm{~K})$ & $\mathrm{k}(\mathrm{mW} / \mathrm{m} \cdot \mathrm{K})$ & $T(\mathrm{~K})$ & $\mathrm{k}(\mathrm{mW} / \mathrm{m} \cdot \mathrm{K})$ \\
\hline 99.67 & 14.1 & 99.65 & 16.3 \\
107.10 & 15.0 & 107.76 & 17.5 \\
139.11 & 18.5 & 139.01 & 21.2 \\
169.15 & 22.0 & 169.10 & 24.6 \\
199.48 & 24.6 & 199.49 & 26.6 \\
219.61 & 25.1 & 219.64 & 25.7 \\
229.69 & 25.3 & 229.71 & 24.8 \\
239.86 & 24.6 & 239.86 & 23.9 \\
254.97 & 23.7 & 254.90 & 24.1 \\
270.39 & 21.2 & 270.40 & 25.5 \\
280.16 & 21.4 & 280.07 & 26.6 \\
290.24 & 23.0 & 290.15 & 27.6 \\
305.77 & 24.8 & 305.71 & 29.3 \\
305.78 & 24.9 & 330.40 & 31.4 \\
330.18 & 27.2 & 330.62 & 33.4 \\
351.19 & 28.3 & 351.24 & 34.1
\end{tabular}

Thermal expansion - The apparatus used to make the thermal expansion measurements presented below was developed to allow large specimens, which may be inhomogeneous and/or anisotropic, to be studied.

A schematic of the dilatometer is shown in figure 9. Operation of the system involves reflecting a laser-light beam onto a mirror inside the environmental chamber. The mirror is balanced on tripod fulcrum points with two points resting on a reference material and one point on the specimen. As the relative lengths of the reference and specimen materials change with temperature, inclination of the mirror changes and the reflected beam is deflected. The beam deflection is sensed with a photocell. This deflection can be related to the relative change in lengths of the specimen and reference materials.

The invar hang rods, which support the specimen-reference-mirror group, change length as the system temperature profile changes. Small corrections based on temperature measurements along their length are made in the analysis of the 


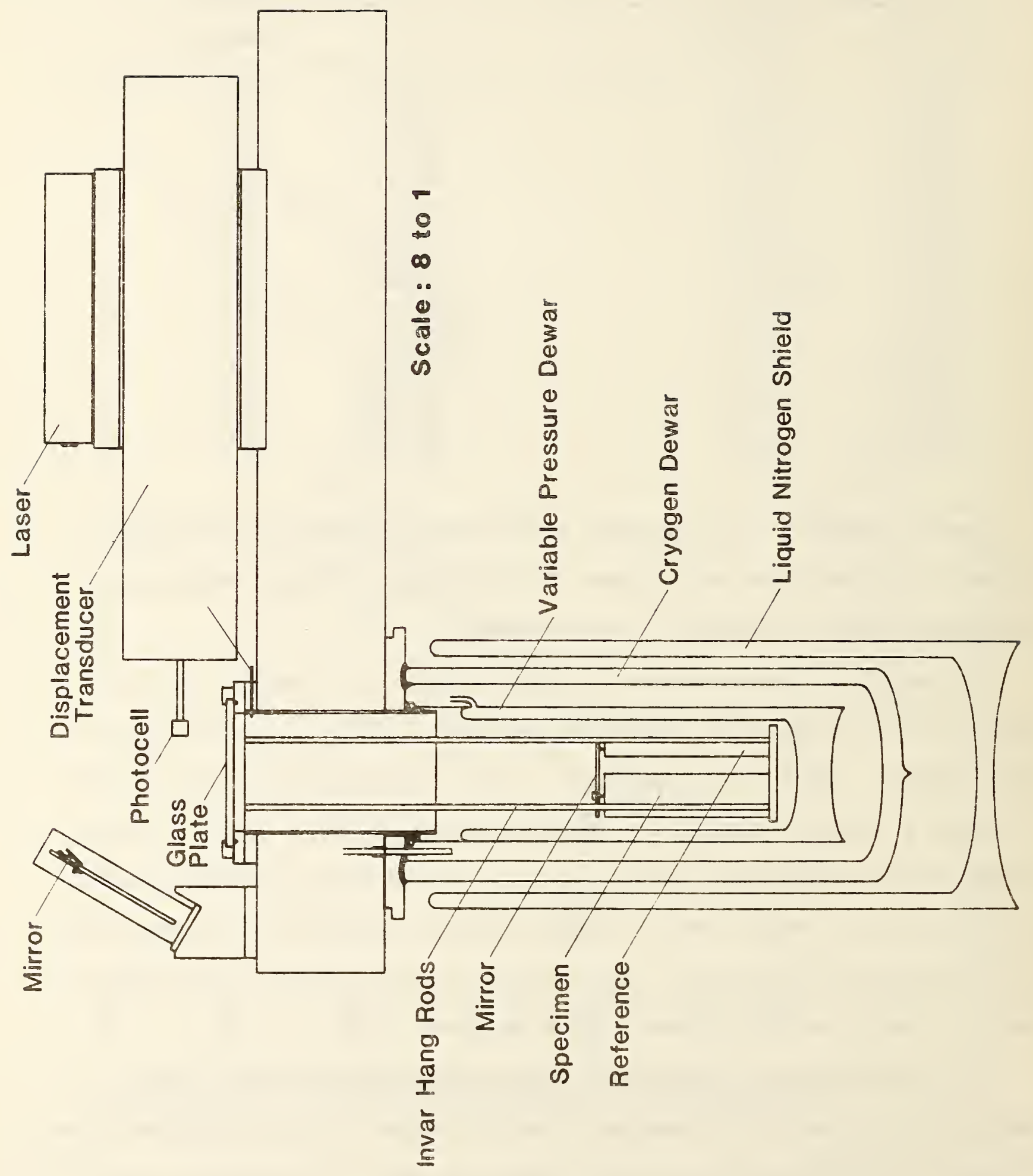

0
0
0
0
0
0
0
0
0
0
0
0
0
0
0
0
0
0
0
0
0
0
0
0
0
0
4
0
0
0
0
0
0
0
0
0
0
0
0
0
0
0
0
0
0
0
0
0
0

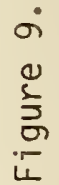


data. A small correction due to the temperature dependent change in length of the reflecting mirror is also made.

The thermal environment is established by balancing joule heating from an electrical heater surrounding the specimen-reference-mirror group and refrigeration obtained from either liquid nitrogen or liquid helium in the cryogen dewar (fig. 9). The electrical heater, not shown in this figure, is wrapped on a right-elliptical cylinder made of $1 / 8$ inch copper and situated around, but not touching, the specimen or reference. Temperatures along the length of the $10 \mathrm{~cm}$ specimen can be maintained within a few millidegrees for a minimum of an hour.

The results of a calibration test using two reference materials, OFHC copper (Kirby and Hahn, 1975) and fused-silica (Kirby and Hahn, 1971), indicate that the total error in measuring the thermal expansion of OFHC copper relative to that of fused silica was $\pm 5 \mu \mathrm{m}$ for a $10 \mathrm{~cm}$ OFHC specimen. The $2 \sigma$ random error for this calibration was $\pm 3 \mu \mathrm{m}$.

Experimental values of thermal expansion for the polyurethane foams are shown in figures 10,11 , and 12 . Discrete points represent the experimental data and the solid curves result from three-term, second-order polynomial fits to these points. The reference material was OFHC copper in the tests on PU32 and PU96, and fused-silica in the tests on PU64.

Polynomial coefficients, obtained by least squares, are listed in table 8. The polynomials are of the form

$$
\text { Delta } L / L=\sum_{i=1}^{3} A_{j} T^{(i-1)}
$$




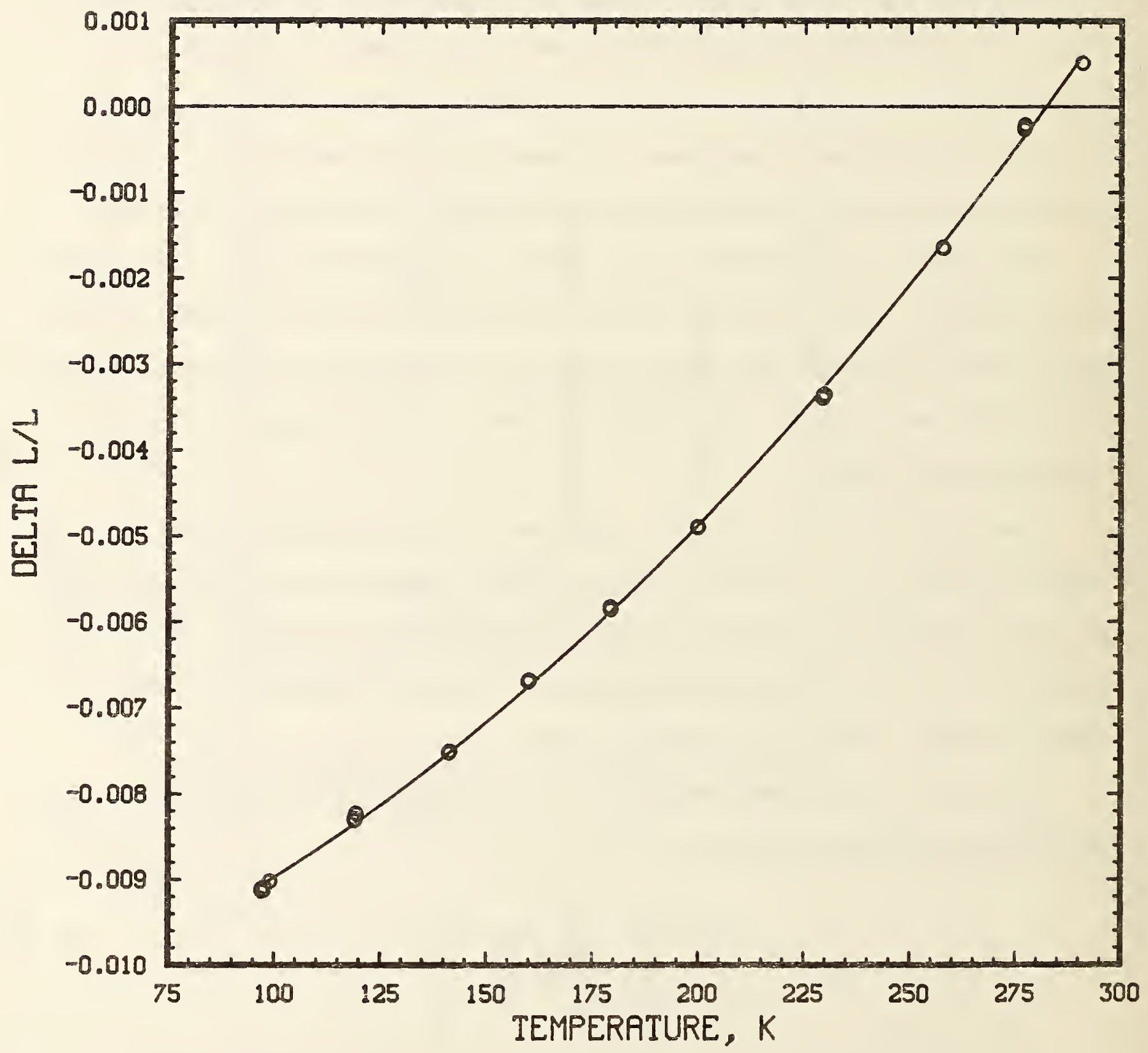

Figure 10. Thermal expansion of a $32-\mathrm{kg} / \mathrm{m}^{3}$ polyurethane foam specimen. Experimental data are represented by discrete points and the solid line represents a three-term polynomial fit to these data. The reference temperature is $281.997 \mathrm{~K}$. 


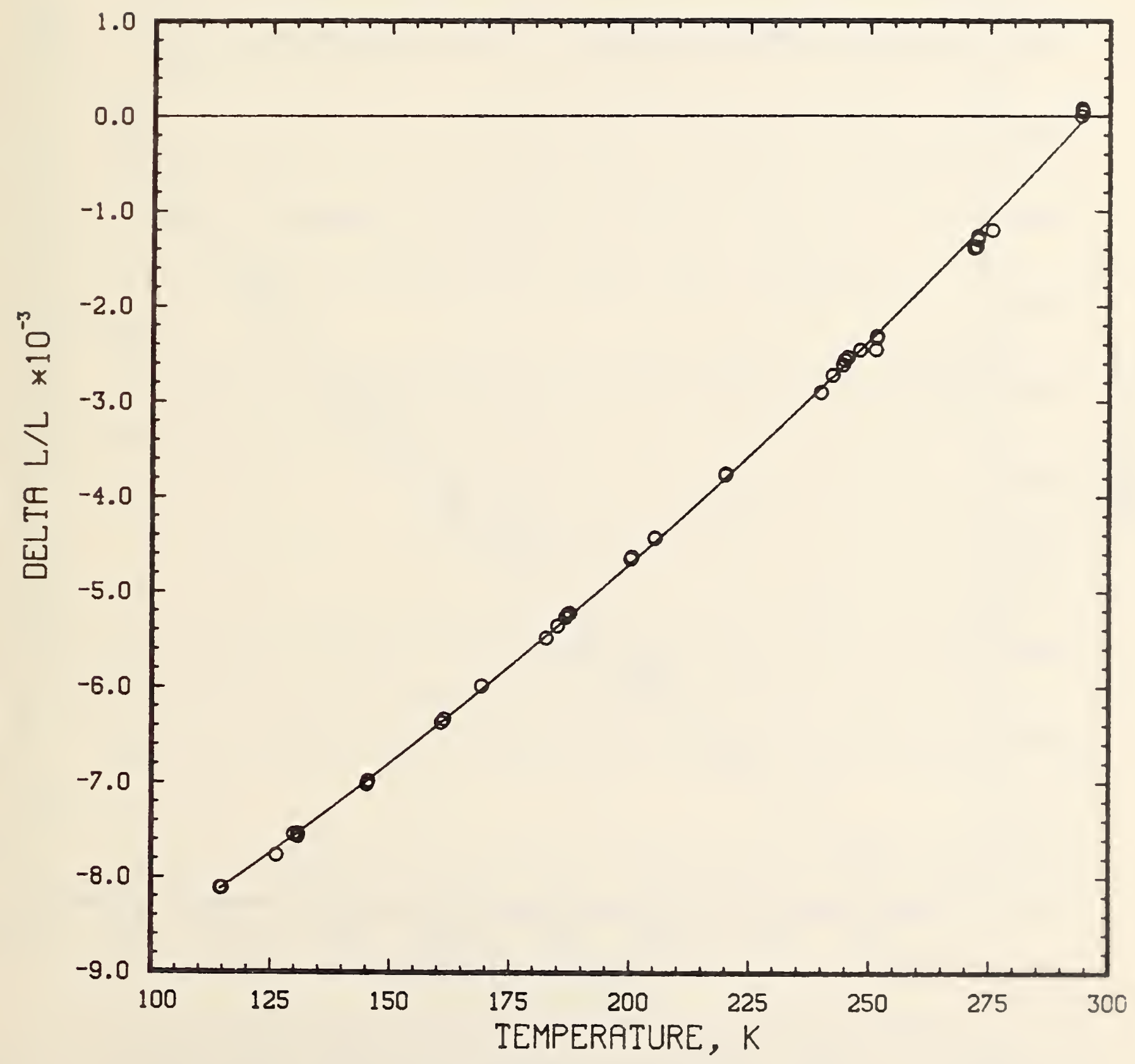

Figure 11. Therrial expansion of a $54-\mathrm{kg} / \mathrm{m}^{3}$ polyurethane foam specinen. Experimental data are represented by discrete points and the solid line represents a three-term polynomial fit to these data. The reference temperature is $295.180 \mathrm{~K}$ 


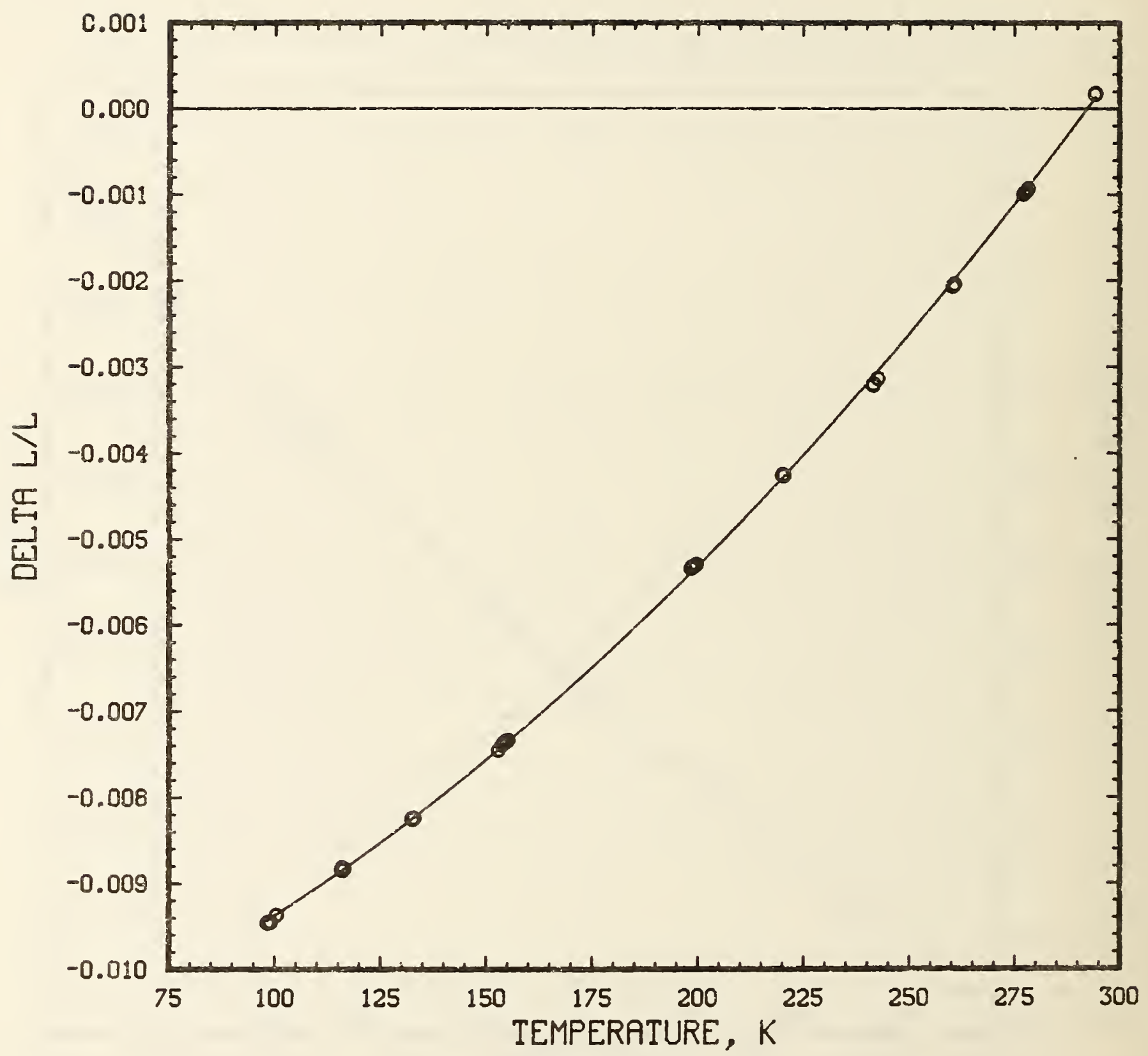

Figure 12. Thermal expansion of a $95-\mathrm{kg} / \mathrm{m}^{3}$ polyurethane foam specimen. Experimental data are represented by discrete points and the solid line represents a three-term polynomial fit to these data. The reference temperature is 29?.227 K. 
Table 8. Polynomial coefficients representing the measured thermal expansion of $32-, 64-$, and $96-\mathrm{kg} / \mathrm{m}^{3}$ polyurethane foams. Reference temperature is $293 \mathrm{~K}$.

\begin{tabular}{cccc} 
Coefficient & PU32 & PU64 & PU96 \\
\hline$A_{1}$ & $-1.1825396 \times 10^{-2}$ & $-1.1348273 \times 10^{-2}$ & $-1.1727014 \times 10^{-2}$ \\
$A_{2}$ & $1.0877846 \times 10^{-5}$ & $2.3112134 \times 10^{-5}$ & $1.4204079 \times 10^{-5}$ \\
$A_{3}$ & $1.0062071 \times 10^{-7}$ & $5.3307753 \times 10^{-8}$ & $8.8122390 \times 10^{-8}$ \\
\hline
\end{tabular}

The constant terms, $A_{1}$, have been algebraically shifted to reference the fitted data to $293 \mathrm{~K}$. Adjustments to the original constant coefficients were -7.56 $\times 10^{-4}, 1.19 \times 10^{-4}$, and $-5.09 \times 10^{-5}$ for PU32, PU64, and PU96 respectively.

The coefficient of thermal expansion (CTE) is given as the temperature derivative of Delta $L / L$ and is of the form

$$
C T E=\sum_{i=1}^{3}(i-1) A_{i} T^{(i-2)}
$$

Tabulated values of Delta $L / L$ and CTE, obtained using eqs (2) and (3) and the appropriate coefficients from table 8 , are given in tables 9, 10, and 11 .

Composite curves of Delta $L / L$ and CTE for the three foams are given in figures 13 and 14.

Mechanical properties - The tensile, compressive, and shear properties of the polyurethane foams were determined using the test fixtures shown in figure 15. These fixtures consist of concentric overlapping cylinders and operate on the principle that capacitance between the cylinders changes as a function of overlapping areas (Reed, Arvidson, and Durcholz, 1973). The systems were specifically developed for use with soft viscoelastic materials such as expanded plastic foams. 


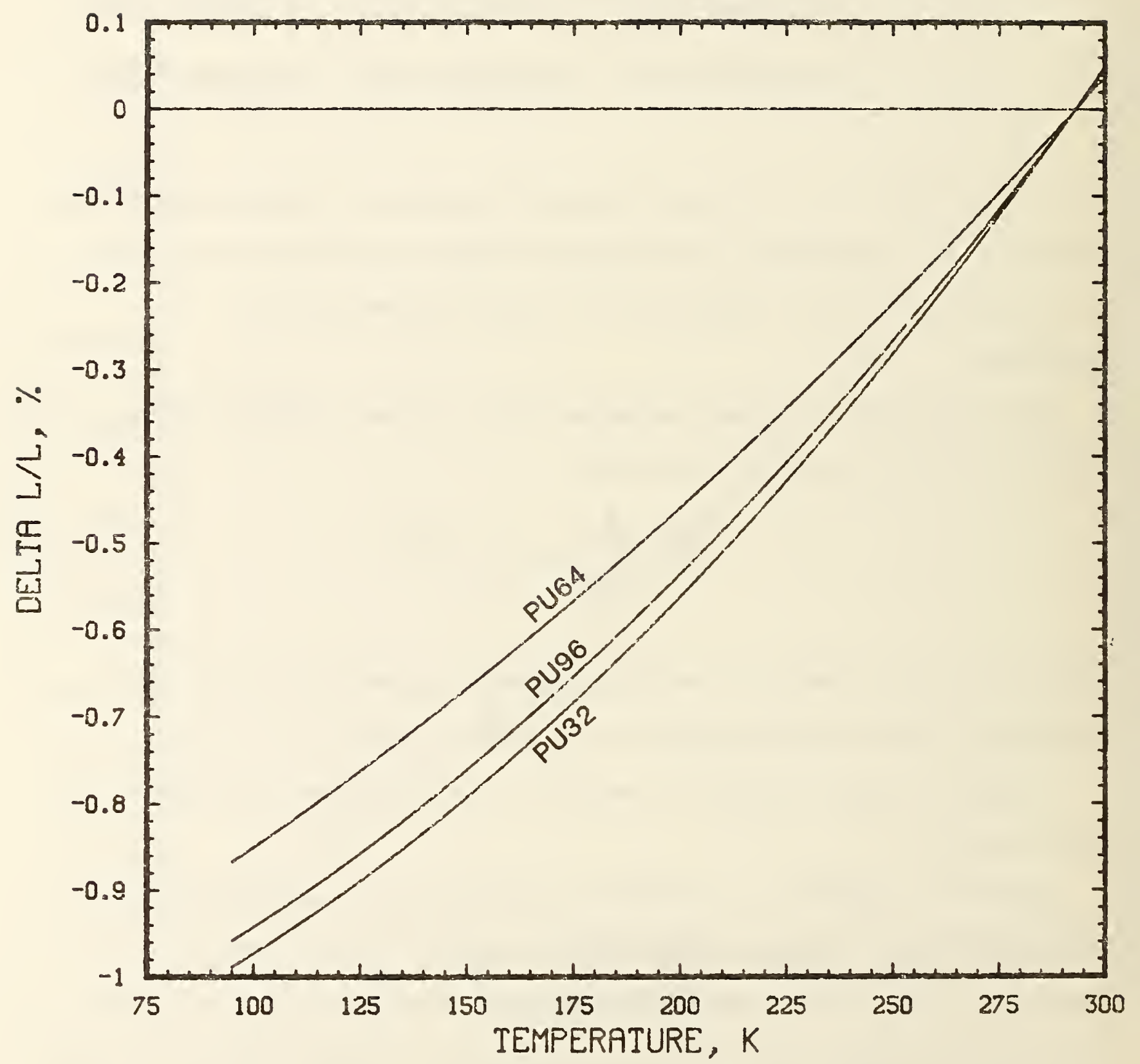

Figure 13. Results of three-term polynomial fits to the thermal expansion of $32-, 64-$, and $90-\mathrm{kg} / \mathrm{m}^{3}$ polyurethane foam specimens. Reference temperature is $293 \mathrm{~K}$. 


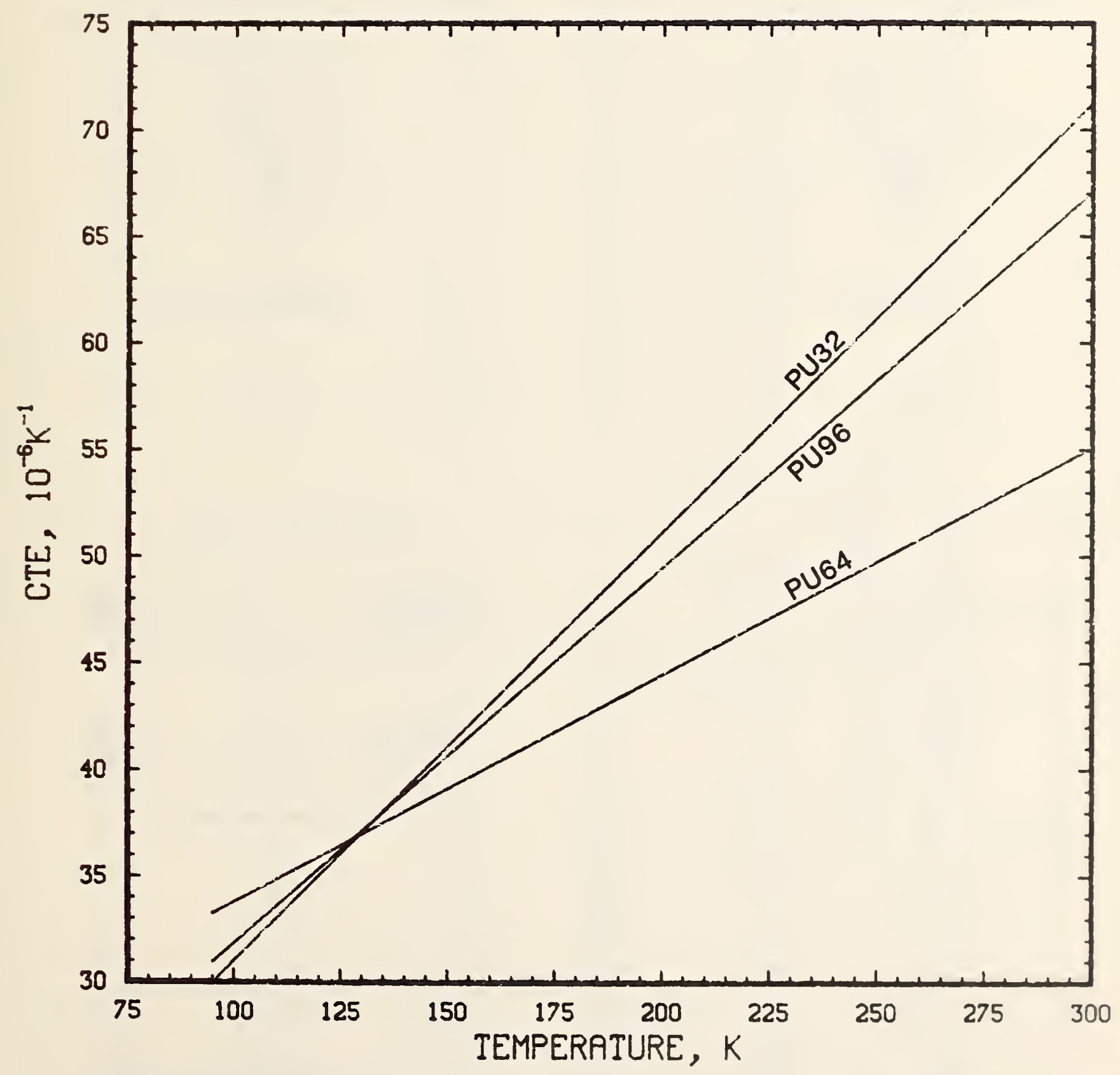

Figure 14. Coefficient of thermal expansion relationships resulting from temperature derivatives of three-term polynomial fits to therinal expansion data of $32-, 64-$, and $96-\mathrm{kg} / \mathrm{m}^{3}$ polyurethane foam specimens. 


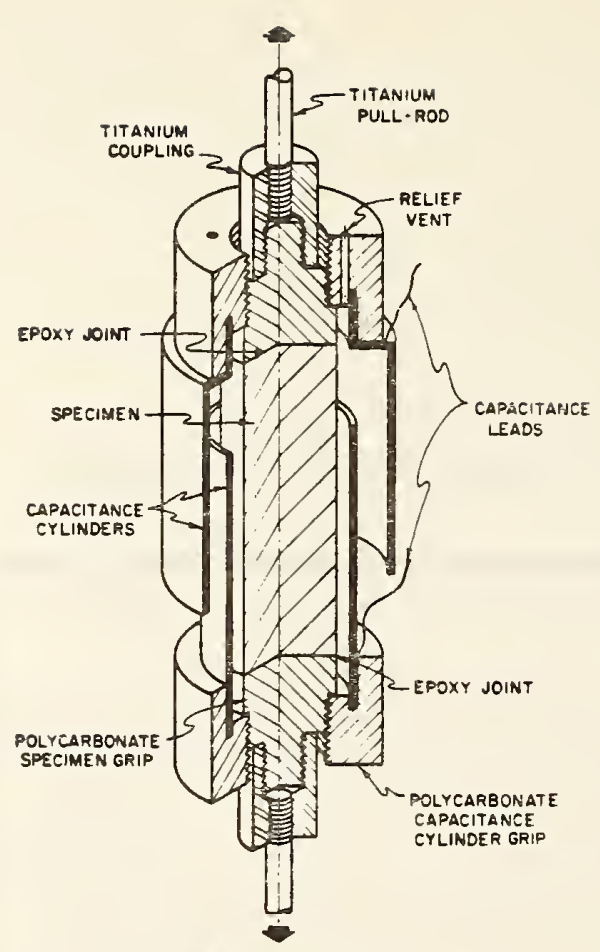

Tensile

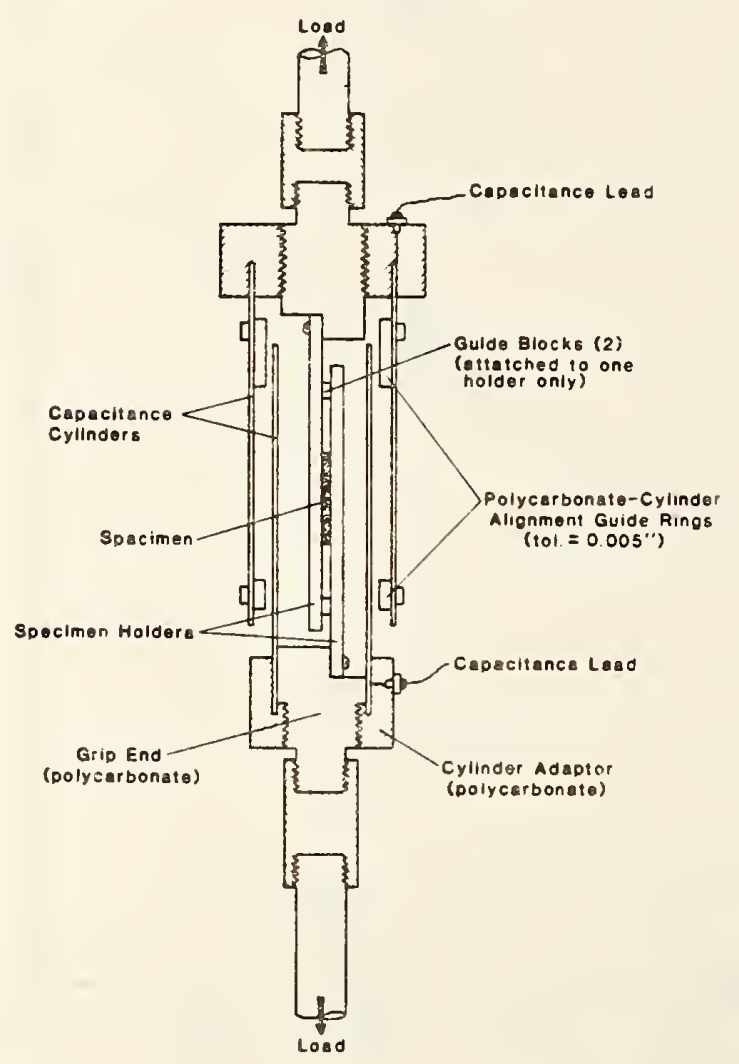

Shear

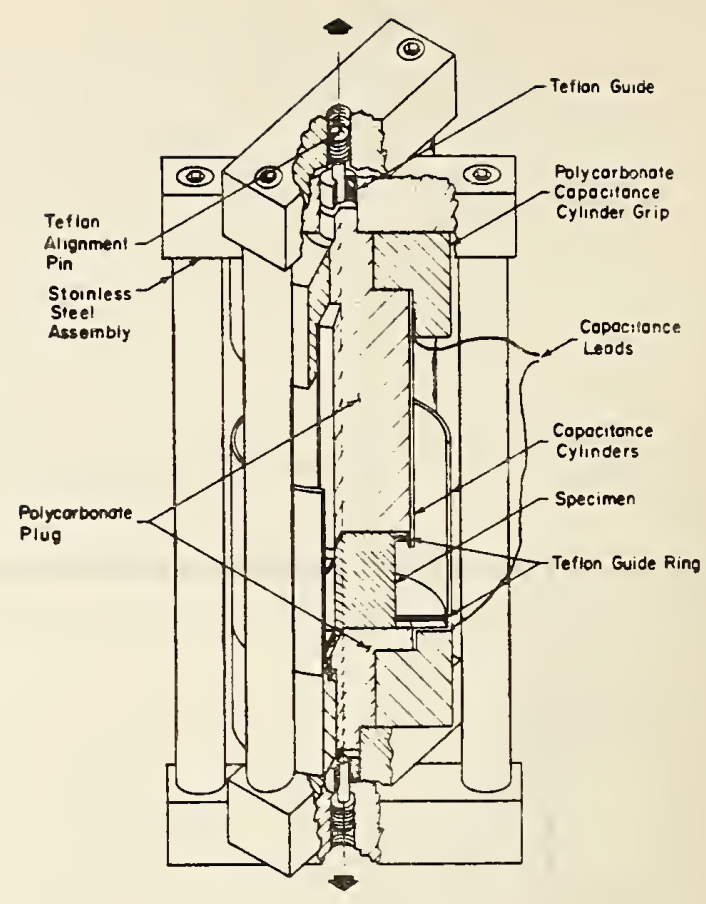

Compressive
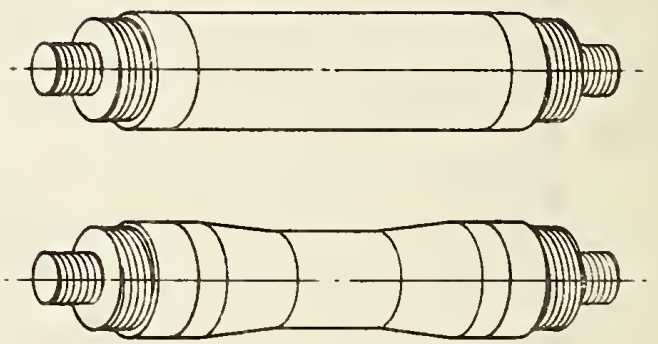

RIGID FOAM SPECIMEN ASSEMBLIES

\section{Tensile Specimen}

Figure 15. Extensometer systems which utilize the capacitance of concentric cylinders. Uniform and reduced section tensile specimen geometries are also illustrated. 
Table 9. Thermal expansion and coefficient of thermal expansion for a $32-\mathrm{kg} / \mathrm{m}^{3}$ polyurethane foam.

\begin{tabular}{rccccc}
$\begin{array}{c}T \\
(\mathrm{~K})\end{array}$ & $\begin{array}{c}\text { Delta L/L } \\
(\%)\end{array}$ & $\begin{array}{c}\text { CTE } \\
\left(10^{-6} \mathrm{~K}^{-1}\right)\end{array}$ & $\begin{array}{c}\mathrm{T} \\
(\mathrm{K})\end{array}$ & $\begin{array}{c}\text { Delta L/L } \\
(\%)\end{array}$ & $\begin{array}{c}\text { CTE } \\
\left(10^{-6} \mathrm{~K}^{-1}\right)\end{array}$ \\
\hline 95 & -.988 & 30.0 & 200 & -.562 & 51.1 \\
100 & -.973 & 31.0 & 205 & -.537 & 52.1 \\
105 & -.957 & 32.0 & 210 & -.510 & 53.1 \\
110 & -.941 & 33.0 & 215 & -.484 & 54.1 \\
115 & -.924 & 34.0 & 220 & -.456 & 55.2 \\
120 & -.907 & 35.0 & 225 & -.428 & 56.2 \\
125 & -.889 & 36.0 & 230 & -.400 & 57.2 \\
130 & -.871 & 37.0 & 235 & -.371 & 58.2 \\
135 & -.852 & 38.0 & 240 & -.342 & 59.2 \\
140 & -.833 & 39.1 & 245 & -.312 & 60.2 \\
145 & -.813 & 40.1 & 250 & -.282 & 61.2 \\
150 & -.793 & 41.1 & 255 & -.251 & 62.2 \\
155 & -.772 & 42.1 & 260 & -.220 & 63.2 \\
160 & -.751 & 43.1 & 265 & -.188 & 64.2 \\
165 & -.729 & 44.1 & 270 & -.155 & 65.2 \\
170 & -.707 & 45.1 & 275 & -.122 & 66.2 \\
175 & -.684 & 46.1 & 280 & -.089 & 67.2 \\
180 & -.661 & 47.1 & 285 & -.055 & 68.2 \\
185 & -.637 & 48.1 & 290 & -.021 & 69.2 \\
190 & -.613 & 49.1 & 295 & .014 & 70.2 \\
195 & -.588 & 50.1 & 300 & .049 & 71.3
\end{tabular}

Table 10. Thermal expansion and coefficient of thermal expansion for a $64-\mathrm{kg} / \mathrm{m}^{3}$ polyurethane foam.

\begin{tabular}{rccccc}
$\begin{array}{c}\text { T } \\
(\mathrm{K})\end{array}$ & $\begin{array}{c}\text { Delta L/L } \\
(\%)\end{array}$ & $\begin{array}{c}\text { CTE } \\
\left(10^{-6} \mathrm{~K}^{-1}\right)\end{array}$ & $\begin{array}{c}\text { T } \\
(\mathrm{K})\end{array}$ & $\begin{array}{c}\text { Delta L/L } \\
(\%)\end{array}$ & $\begin{array}{c}\text { CTE } \\
\left(10^{-5} \mathrm{~K}^{-1}\right)\end{array}$ \\
\hline 95 & -.867 & 33.2 & 200 & -.459 & 44.4 \\
100 & -.850 & 33.8 & 205 & -.437 & 45.0 \\
105 & -.833 & 34.3 & 210 & -.414 & 45.5 \\
110 & -.816 & 34.8 & 215 & -.392 & 46.0 \\
115 & -.799 & 35.4 & 220 & -.368 & 46.6 \\
120 & -.781 & 35.9 & 225 & -.345 & 47.1 \\
125 & -.763 & 36.4 & 230 & -.321 & 47.6 \\
130 & -.744 & 37.0 & 235 & -.297 & 48.2 \\
135 & -.726 & 37.5 & 240 & -.273 & 48.7 \\
140 & -.707 & 38.0 & 245 & -.249 & 49.2 \\
145 & -.688 & 38.6 & 250 & -.224 & 49.8 \\
150 & -.668 & 39.1 & 255 & -.199 & 50.3 \\
155 & -.649 & 39.6 & 260 & -.174 & 50.8 \\
160 & -.629 & 40.2 & 265 & -.148 & 51.4 \\
165 & -.608 & 40.7 & 270 & -.122 & 51.9 \\
170 & -.588 & 41.2 & 275 & -.096 & 52.4 \\
175 & -.567 & 41.8 & 280 & -.070 & 53.0 \\
180 & -.546 & 42.3 & 285 & -.043 & 53.5 \\
185 & -.525 & 42.8 & 290 & -.016 & 54.0 \\
190 & -.503 & 43.4 & 295 & .011 & 54.5 \\
195 & -.481 & 43.9 & 300 & .038 & 55.1 \\
& & & $-35-$ & &
\end{tabular}


Table 11. Thermal expansion and coefficient of thermal expansion for a $96-\mathrm{kg} / \mathrm{m}^{3}$ polyurethane foam.

\begin{tabular}{rccccc}
$\begin{array}{c}T \\
(\mathrm{~K})\end{array}$ & $\begin{array}{c}\text { Delta L/L } \\
(\%)\end{array}$ & $\begin{array}{c}\text { CTE } \\
\left(10^{-6} \mathrm{~K}^{-1}\right)\end{array}$ & $\begin{array}{c}\mathrm{T} \\
(\mathrm{K})\end{array}$ & $\begin{array}{c}\text { Delta } \mathrm{L} / \mathrm{L} \\
(\%)\end{array}$ & $\begin{array}{c}\text { CTE } \\
\left(10^{-6} \mathrm{~K}^{-1}\right)\end{array}$ \\
\hline 95 & -.958 & 30.9 & 200 & -.536 & 49.5 \\
100 & -.943 & 31.8 & 205 & -.511 & 50.3 \\
105 & -.926 & 32.7 & 210 & -.486 & 51.2 \\
110 & -.910 & 33.6 & 215 & -.460 & 52.1 \\
115 & -.893 & 34.5 & 220 & -.434 & 53.0 \\
120 & -.875 & 35.4 & 225 & -.407 & 53.9 \\
125 & -.857 & 36.2 & 230 & -.380 & 54.7 \\
130 & -.839 & 37.1 & 235 & -.352 & 55.6 \\
135 & -.820 & 38.0 & 240 & -.324 & 56.5 \\
140 & -.801 & 38.9 & 245 & -.296 & 57.4 \\
145 & -.781 & 39.8 & 250 & -.267 & 58.3 \\
150 & -.761 & 40.6 & 255 & -.237 & 59.1 \\
155 & -.741 & 41.5 & 260 & -.208 & 60.0 \\
160 & -.720 & 42.4 & 265 & -.177 & 60.9 \\
165 & -.698 & 43.3 & 270 & -.147 & 61.8 \\
170 & -.677 & 44.2 & 275 & -.116 & 62.7 \\
175 & -.654 & 45.0 & 280 & -.084 & 63.6 \\
180 & -.632 & 45.9 & 285 & -.052 & 64.4 \\
185 & -.608 & 46.8 & 290 & -.020 & 65.3 \\
190 & -.585 & 47.7 & 295 & .013 & 66.2 \\
195 & -.561 & 48.6 & 300 & .047 & 67.1
\end{tabular}

This type of extensometer does not attach directly to the specimen so that the effect of instrumentation on the experimental results is negligible. The extensometer works well in cryogenic environments and is linear for large strains (Roberts, Herring, and Hartman, 1968 and NASA, 1975). The capacitance extensometer system had a linearity range in excess of $2.5 \mathrm{~cm}$ when used with the tensile specimens shown in figure $15(5.1 \mathrm{~cm}$ diameter by $10.2 \mathrm{~cm}$ long). These specimen geometries were used to determine all tensile properties. Foam cylinders, epoxied to polycarbonate grip ends, $9.9 \mathrm{~cm}$ in length and $2.9 \mathrm{~cm}$ in diameter were used to determine Young's modulus, proportional limit, yield strength, and elongation. Reduced-section specimens with gage lengths of approximately $5.1 \mathrm{~cm}$, and $1.9 \mathrm{~cm}$ in dianeter, were used to determine ultimate tensile strength. This geometry forced failure to occur within the gage length, thus avoiding a premature failure elsewhere due to biaxial stresses at the epoxied polycarbonate grips. 
The compression specimens were rods $2.54 \mathrm{~cm}$ long and $2.54 \mathrm{~cm}$ in diameter. No grips were required for these specimens and therefore all compressive material properties were determined using this geometry.

The shear specimens, $1.9 \times 2.54 \times 0.4 \mathrm{~cm}$, were epoxied to flat plates and each plate was attached to the tensile pull-rod system. An aluminum cyclinder with a built-in resistive heater and thermocouple was slipped over the specimen plates and used for temperature control and alignment during the tests.

Tests were conducted at $295 \mathrm{~K}$ (air), $111 \mathrm{~K}$ (nitrogen gas), $76 \mathrm{~K}$ (1iquid nitrogen), and $4 \mathrm{~K}$ (liquid helium). A minimum of three samples were tested at each temperature, and in some cases several more were tested to determine material variability. Minimization of thermal shock to the sample was accomplished by using very slow transfer rates of liquid helium or nitrogen. A given test temperature was held for a minimum of 15 minutes prior to testing, in order to ensure that the specimen was isothermal.

Each specimen was conditioned in an environmental chamber for at least four days at $23^{\circ} \mathrm{C}$ and 50 percent relative humidity prior to testing. Tension, compression, and shear tests were conducted using a conventional tension/compression test machine at a strain rate of $5 \times 10^{-3} \mathrm{~min}^{-1}$. Preliminary tests indicated that there was no measurable effect on the mechanical properties due to varying the strain rate from $5 \times 10^{-2}$ to $5 \times 10^{-4} \mathrm{~min}^{-1}$.

The results are presented in tables 12 through 20 and in figures 16 through 40. The error bars on the figures show the data spread from repeated tests. Scatter is typically higher for compression and shear tests than for tensile tests, since the former tests are more sensitive to inisalignment. Two orientations, longitudinal and transverse, are designated in the data. These orientations are relative to the axes of the bulk supplies, with longitudinal being parallel to the z-axis and transverse being parallel to the y-axis (fig. 2 ). 


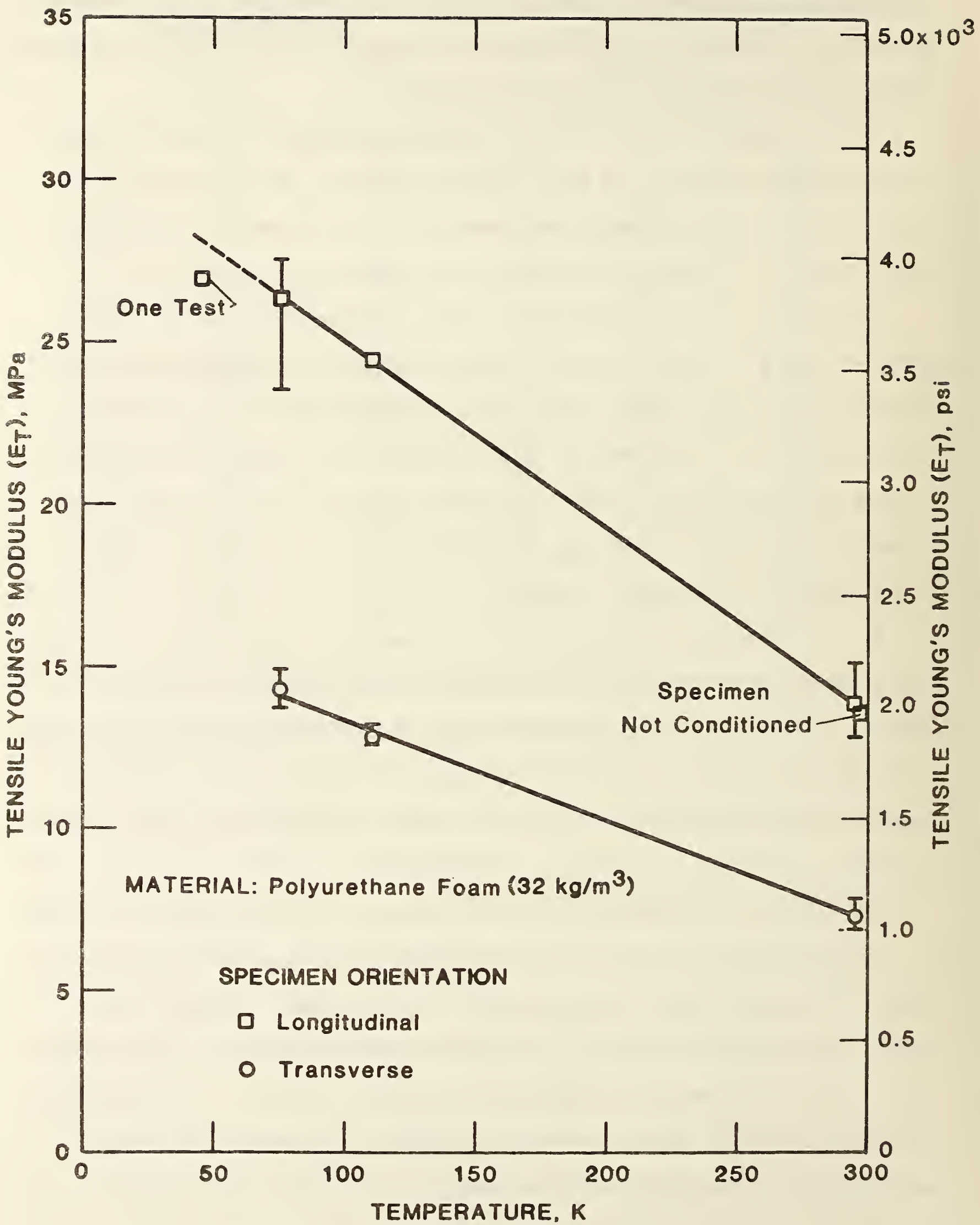

Figure 16. Tensile Young's modulus versus teinperature for a $32-\mathrm{kg} / \mathrm{m}^{3}$ polyurethane foam. 

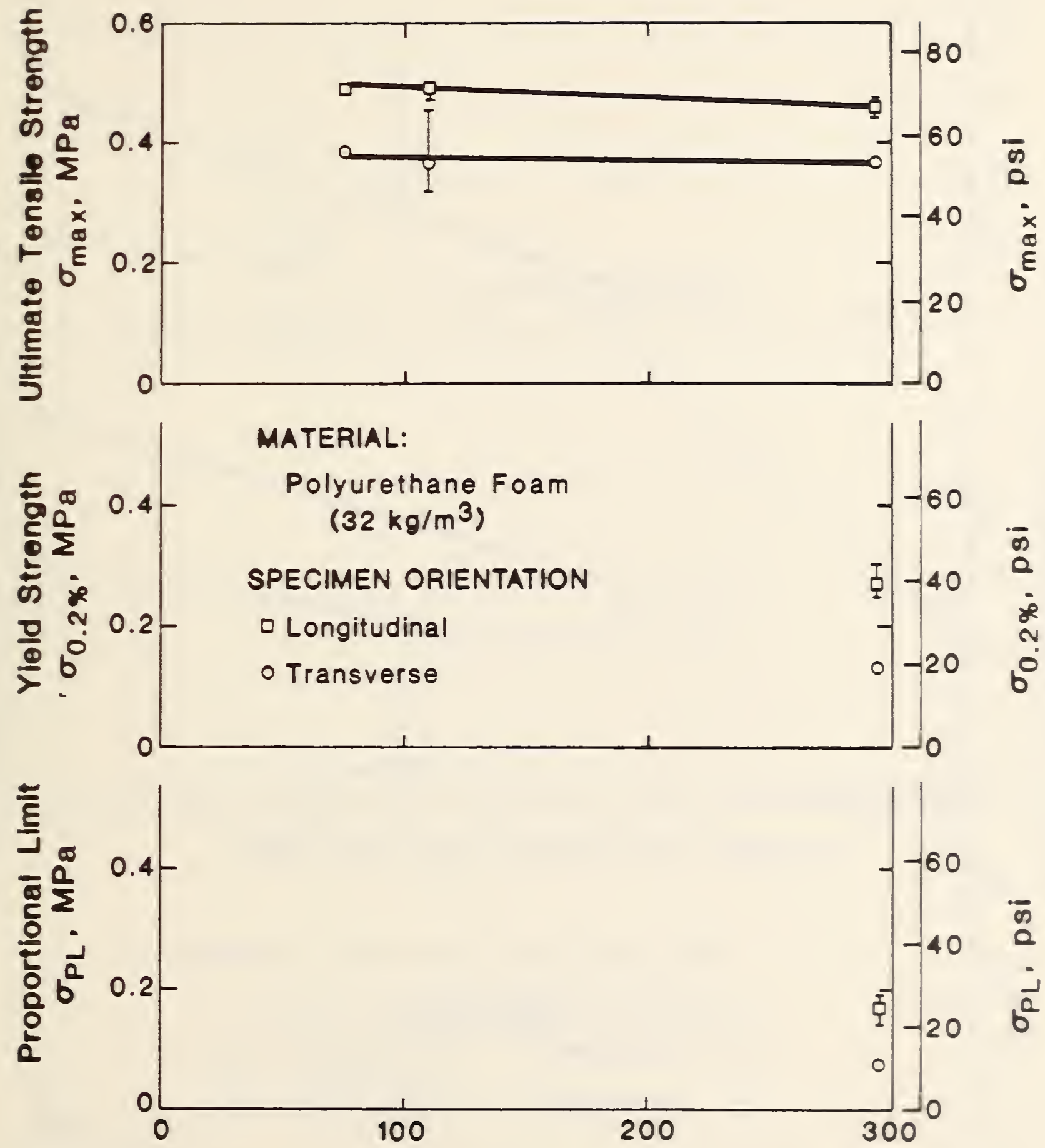

Temperature

Figure 17. Tensile test results: proportional limit, yield strength, and ultimate strength versus teinperature for a $32-\mathrm{kg} / \mathrm{m}^{3}$ polyurethane foam. 


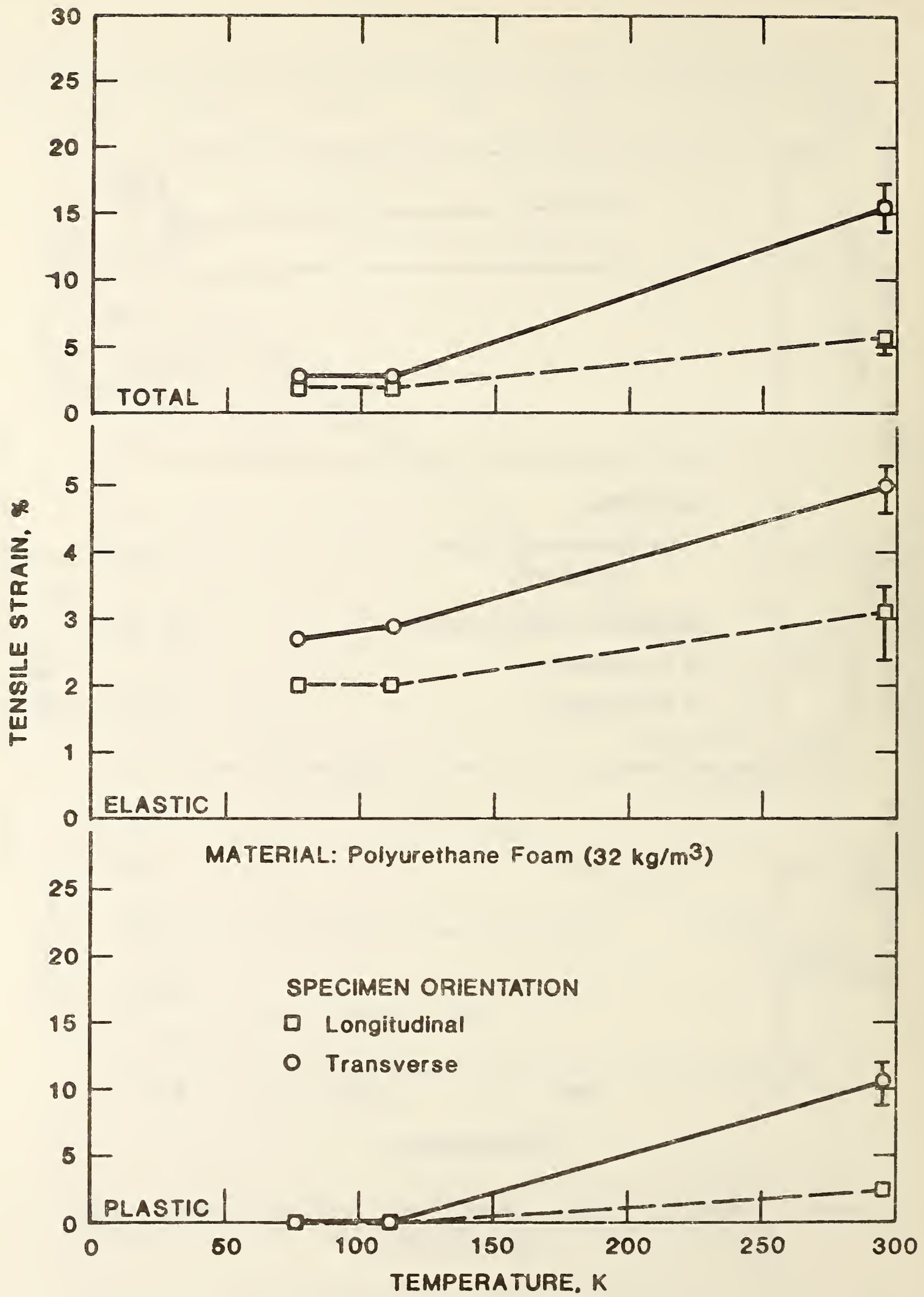

Figure 18. Tensile strain versus temperature for a $32-\mathrm{kg} / \mathrm{m}^{3}$ polyurethane foam. 


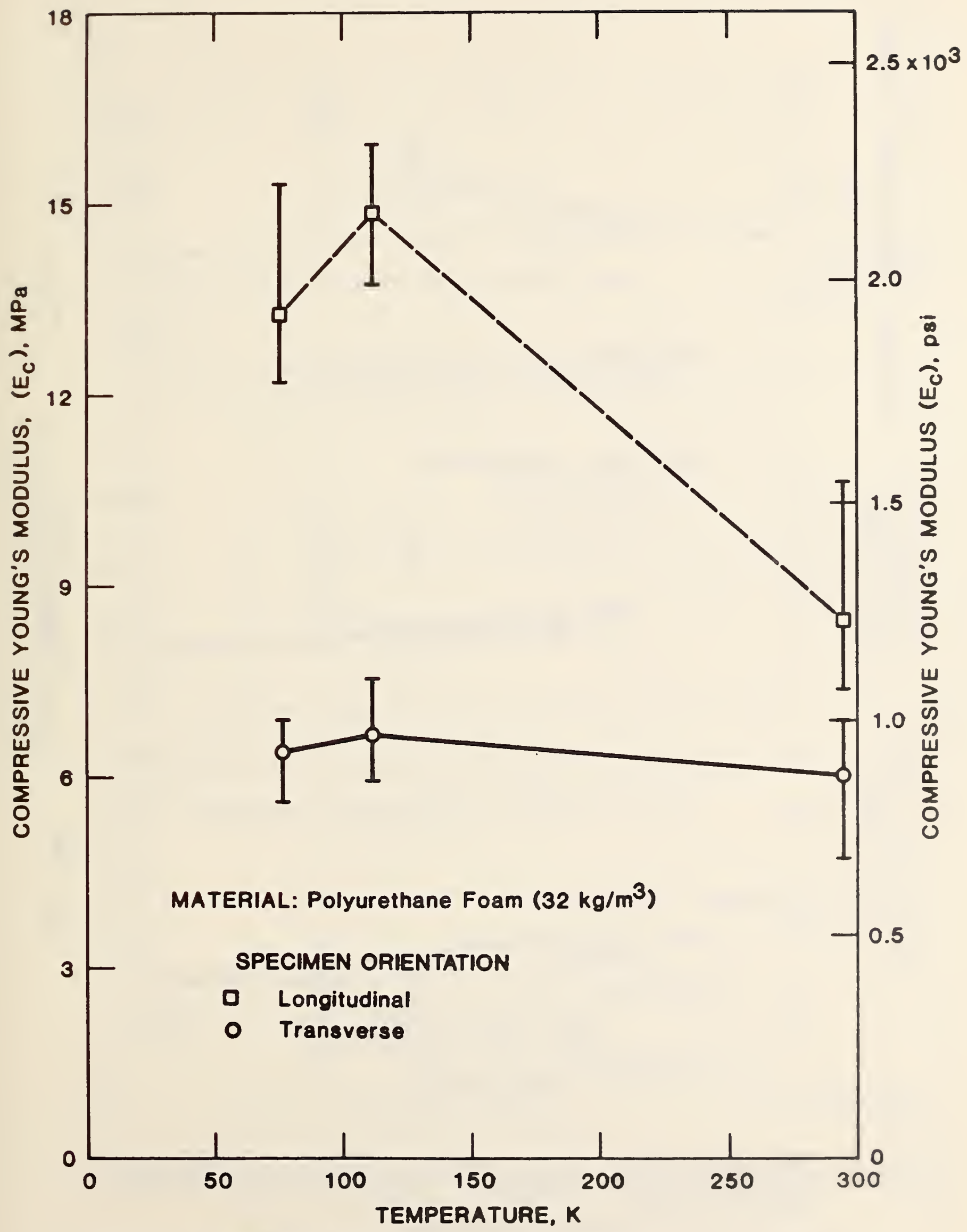

Figure 19. Compressive Young's modulus versus temperature for a $32-\mathrm{kg} / \mathrm{m}^{3}$ polyurethane foam. 


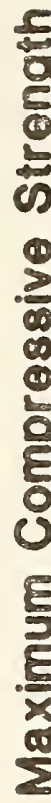

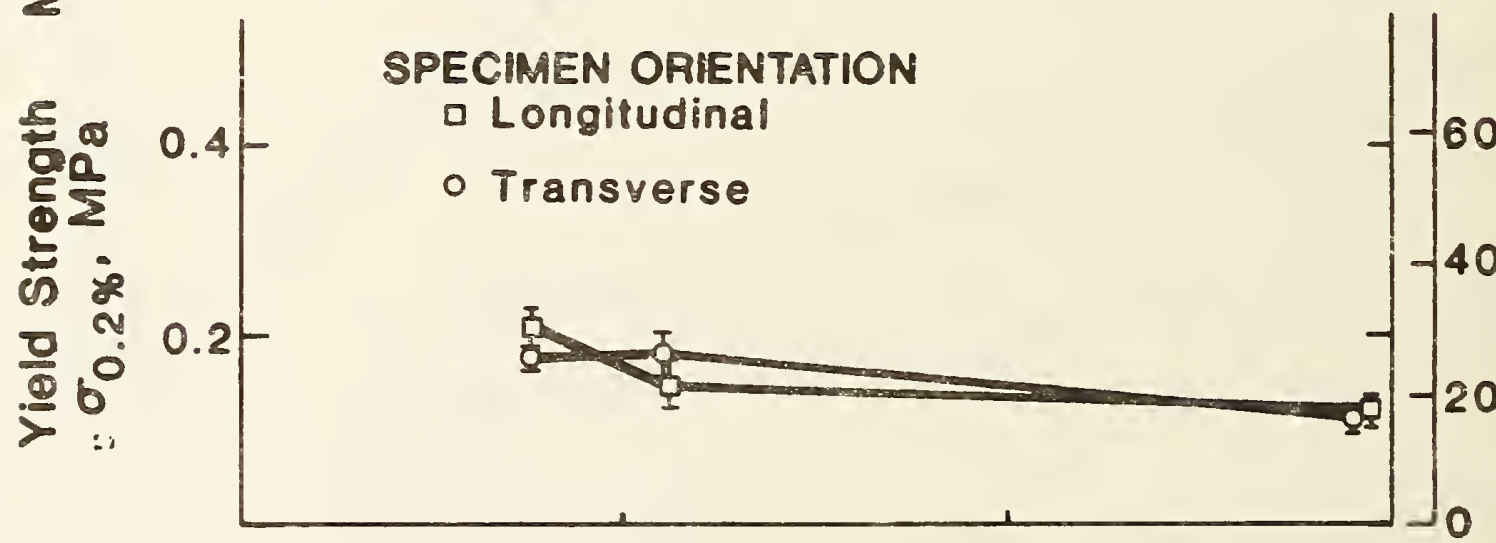

MATERIAL:

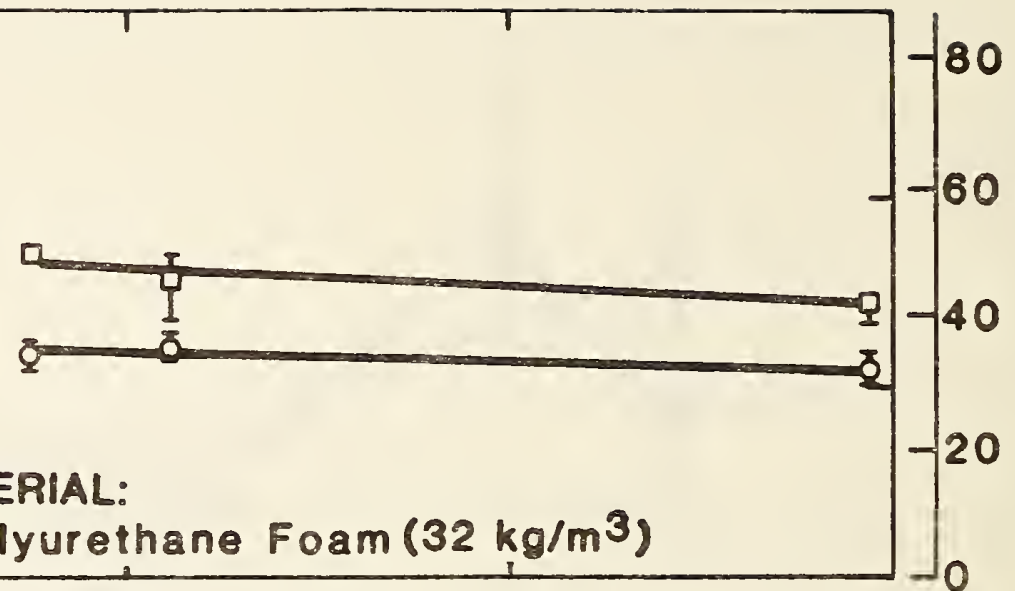

$\overline{0}$
2
$x$
6
6 Polyurethane Foam $\left(32 \mathrm{~kg} / \mathrm{m}^{3}\right)$

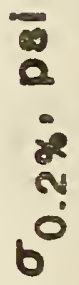

름

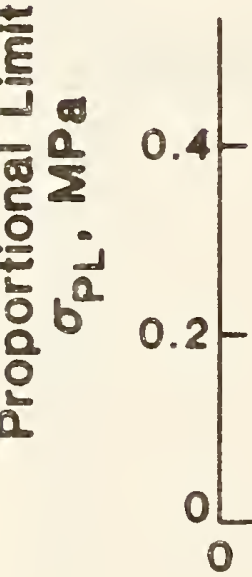

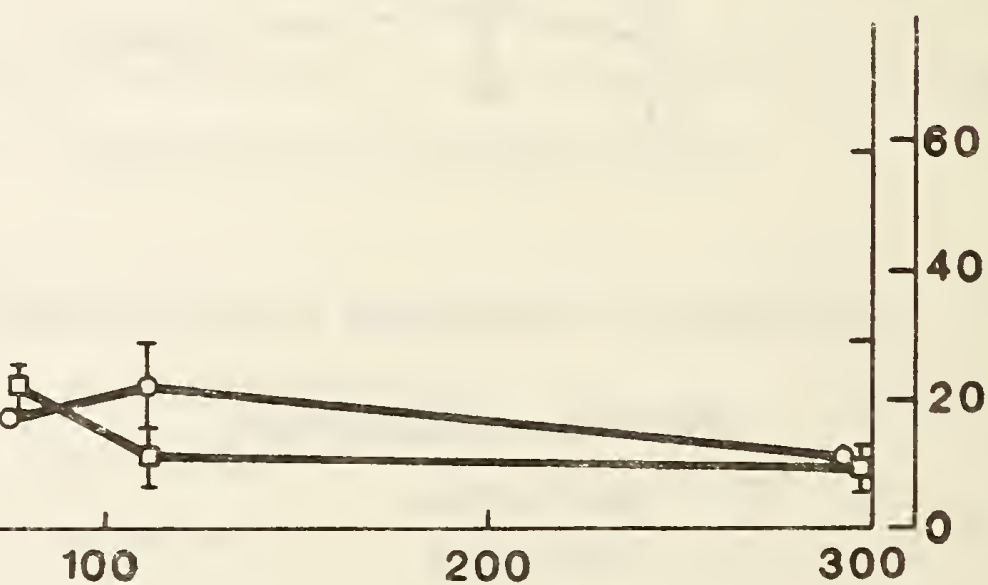

2

Temperature

Figure 20. Compression test results: proportional limit, yield strength and maximum compressive strength versus temperature for a $32-\mathrm{kg} / \mathrm{m}^{3}$ polyurethane foam. 


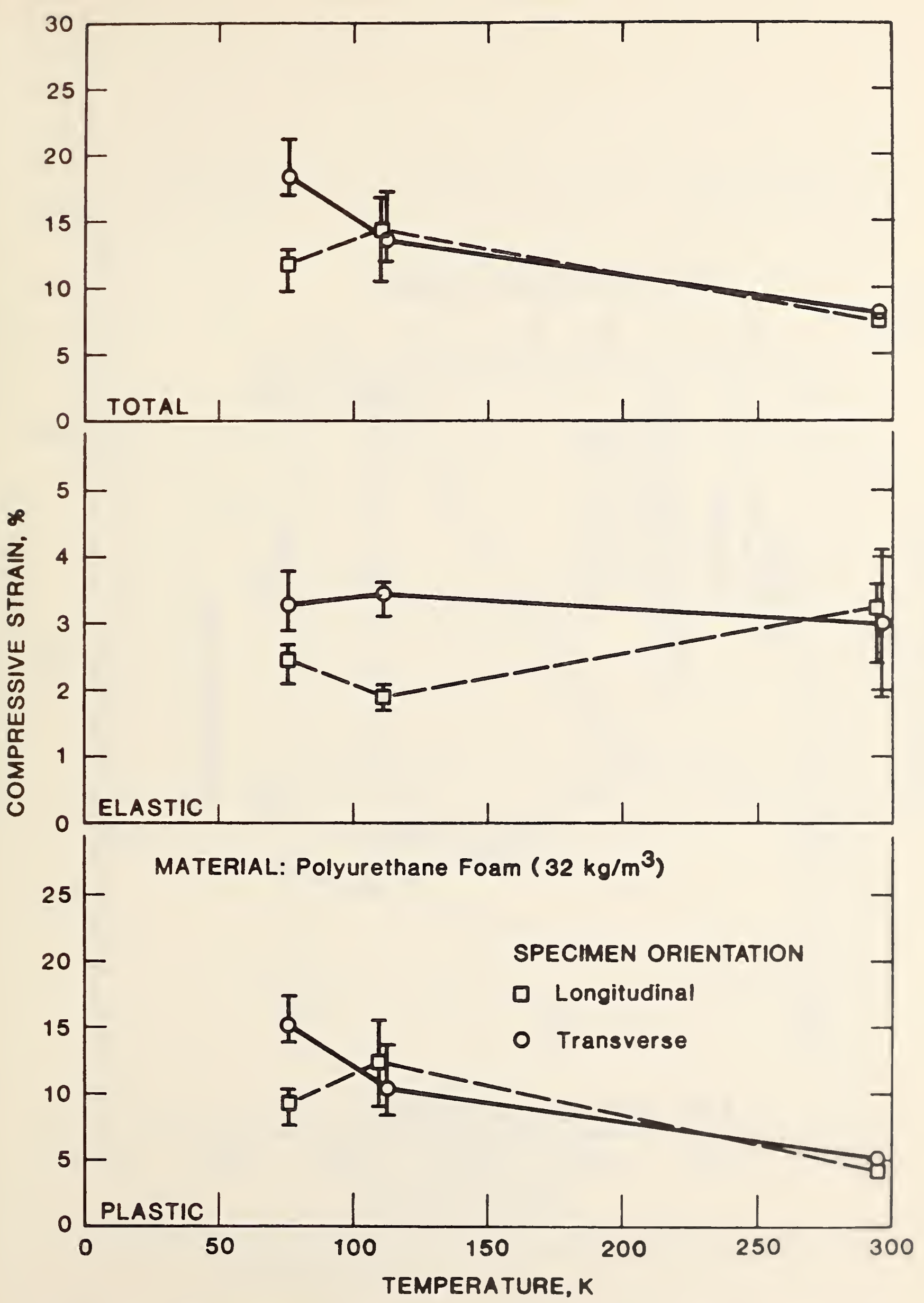

Figure 21. Compressive strain versus temperature for a $32-\mathrm{kg} / \mathrm{m}^{3}$ polyurethane foam. 


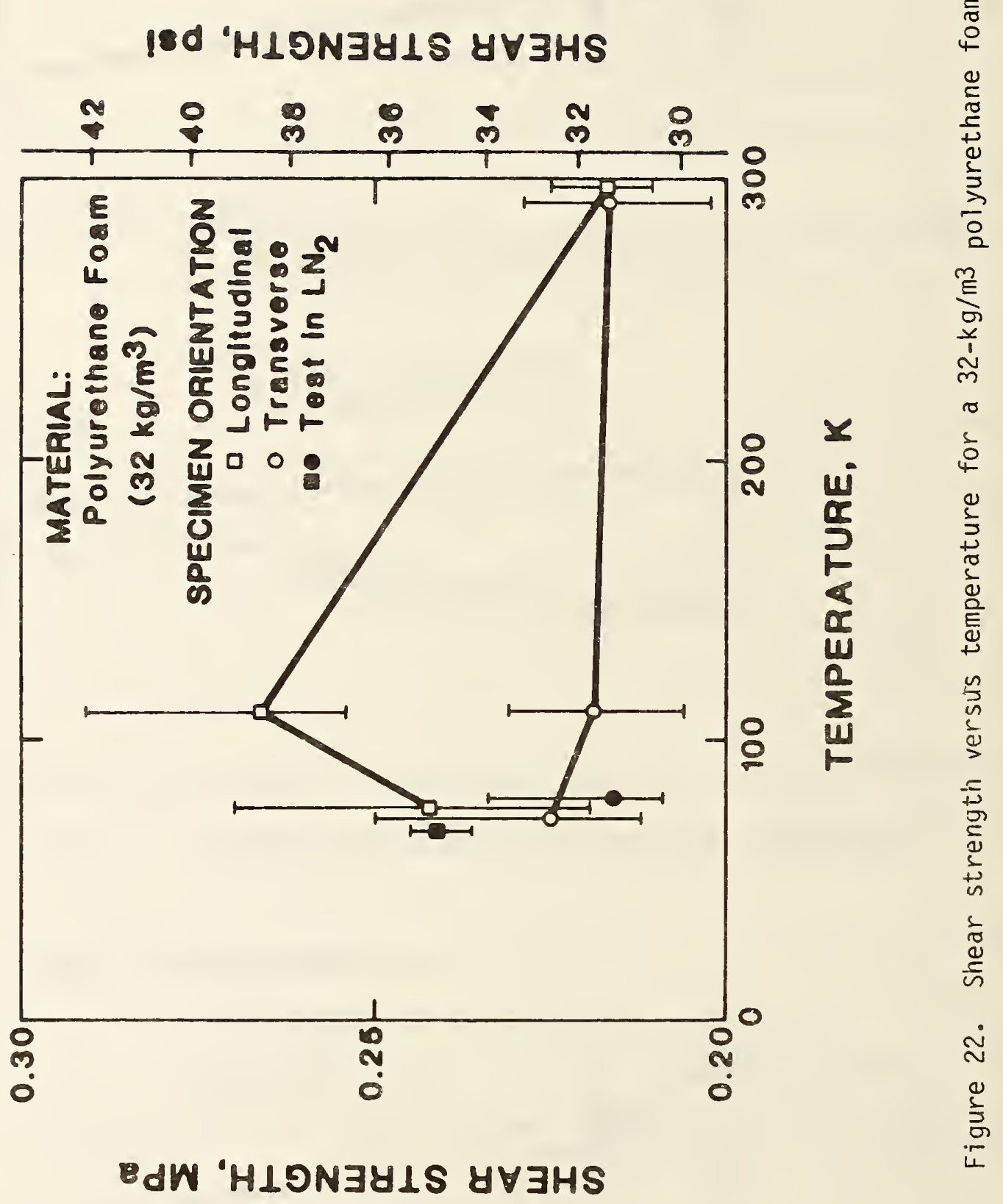




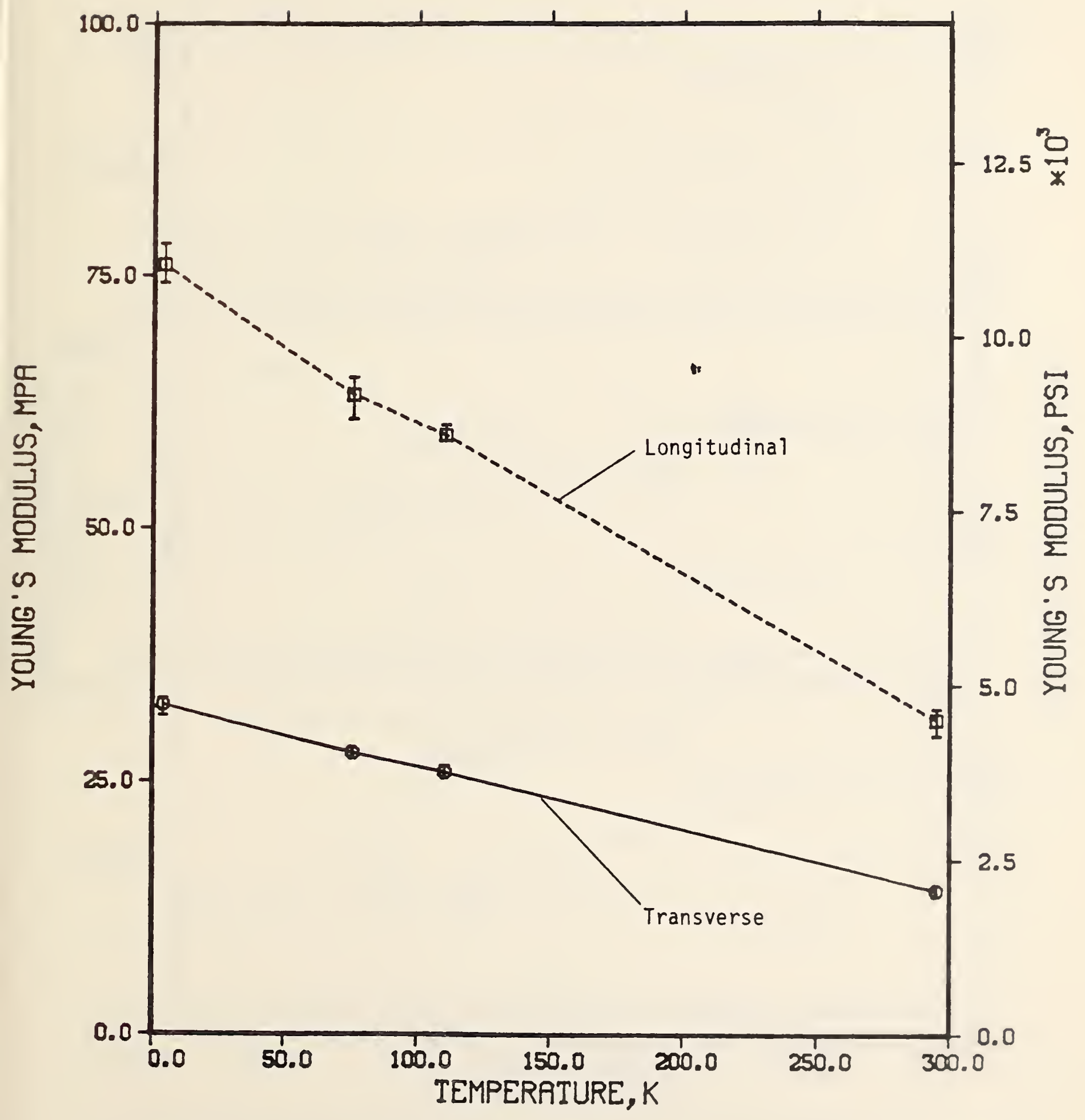

Figure 23. Tensile Young's modulus versus temperature for a $64-\mathrm{kg} / \mathrm{m}^{3}$ polyurethane foam. 


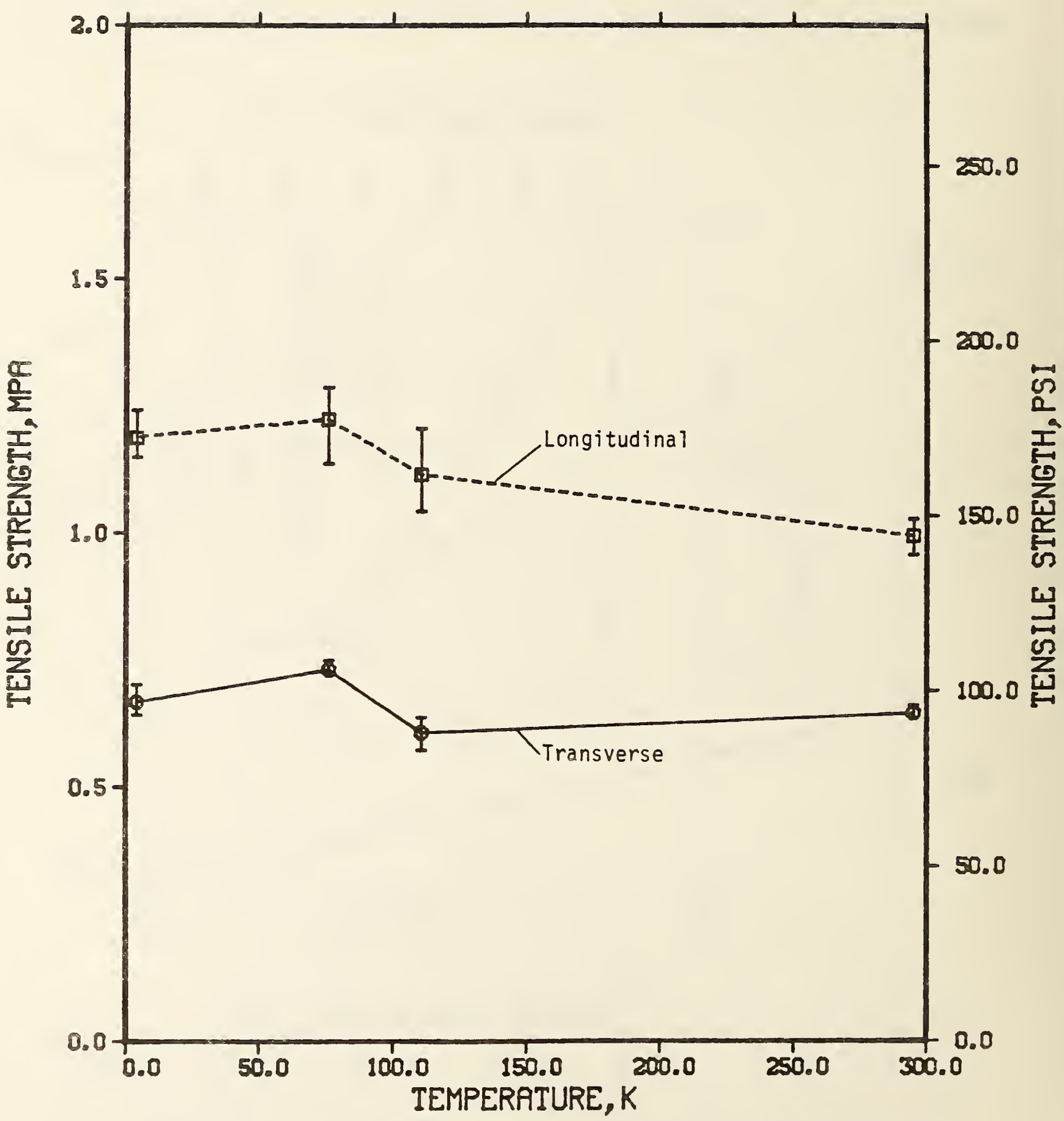

Figure 24. Tensile strength versus temperature for a $64-\mathrm{kg} / \mathrm{m}^{3}$ polyurethane foam. 


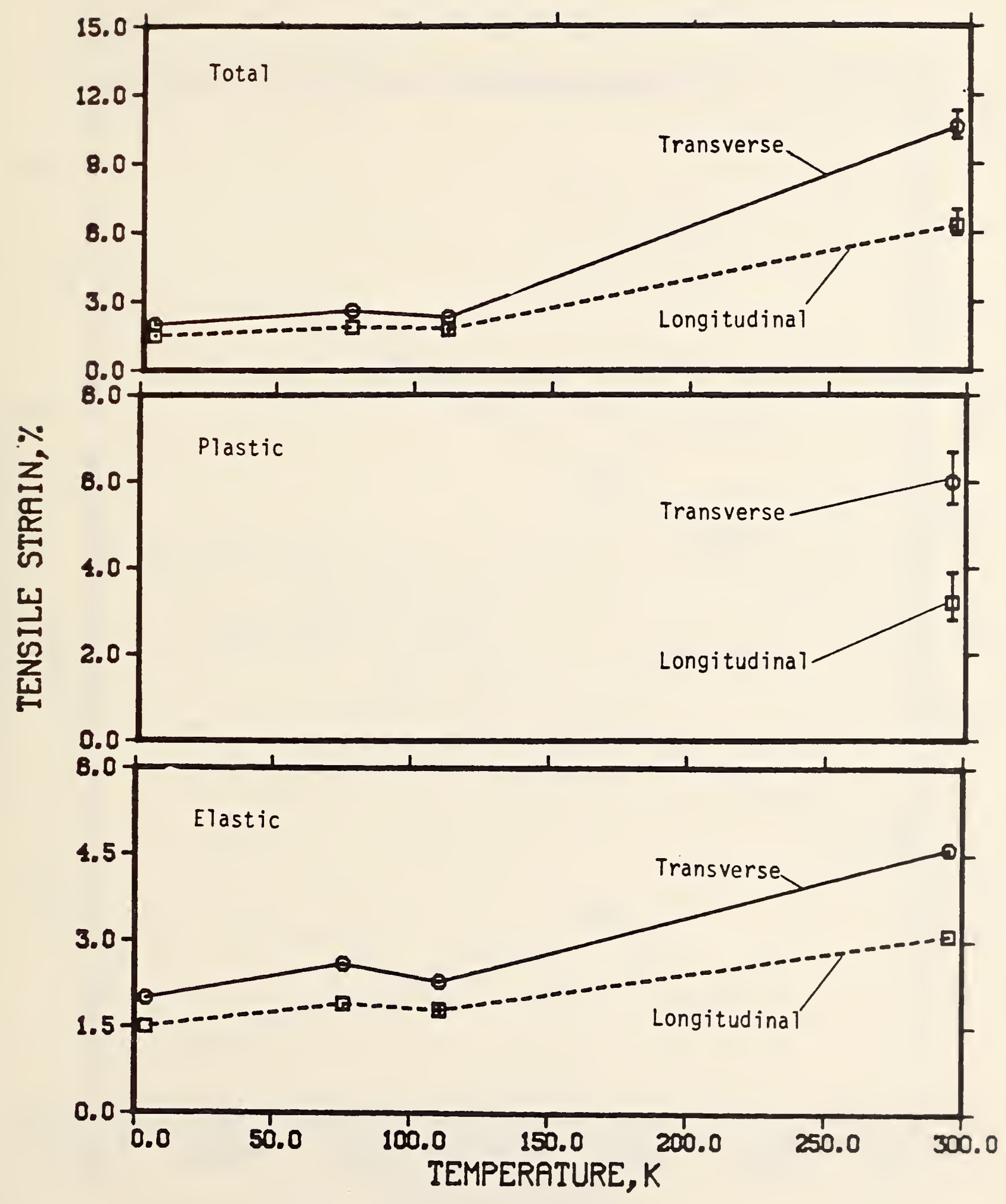

Figure 25. Tensile strain versus temperature for a $64-\mathrm{kg} / \mathrm{m}^{3}$ polyurethane foam. 


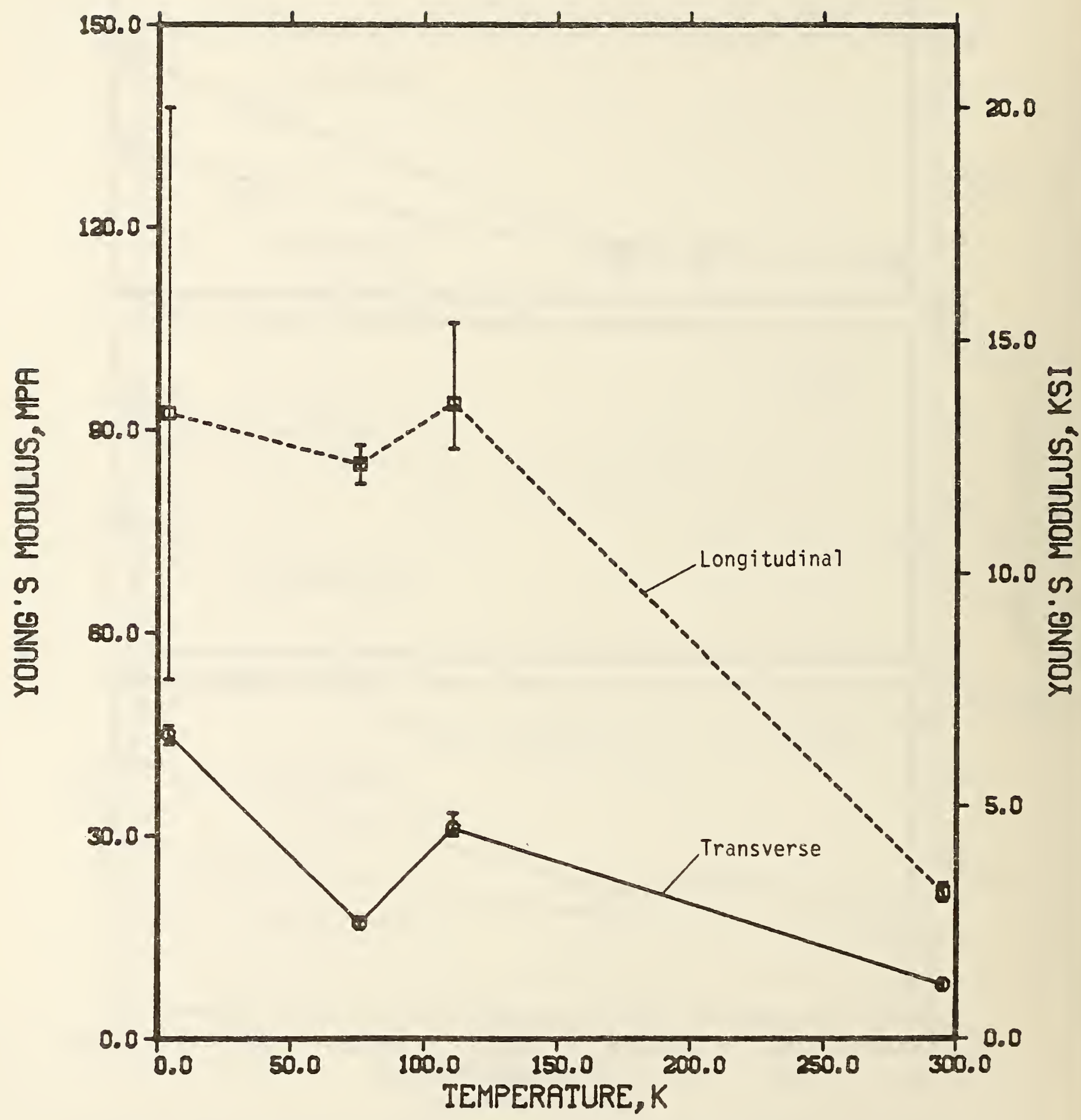

Figure 26. Compressive Young's modulus versus teinperature for a $64-\mathrm{kg} / \mathrm{m}^{3}$ polyurethane foam. 


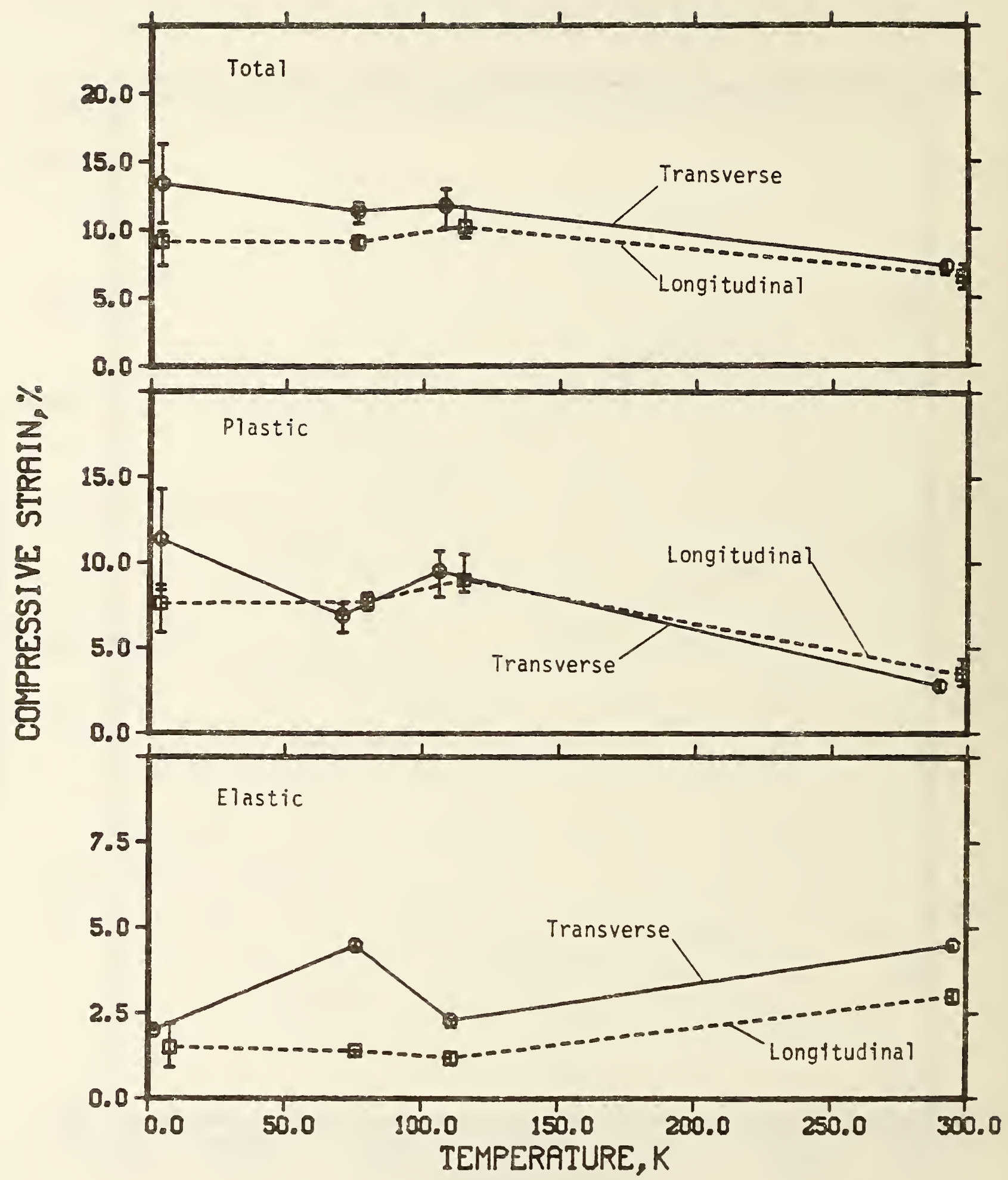

Figure 28. Compressive strain as a function of temperature for a $64-\mathrm{kg} / \mathrm{m}^{3}$ polyurethane foam. 


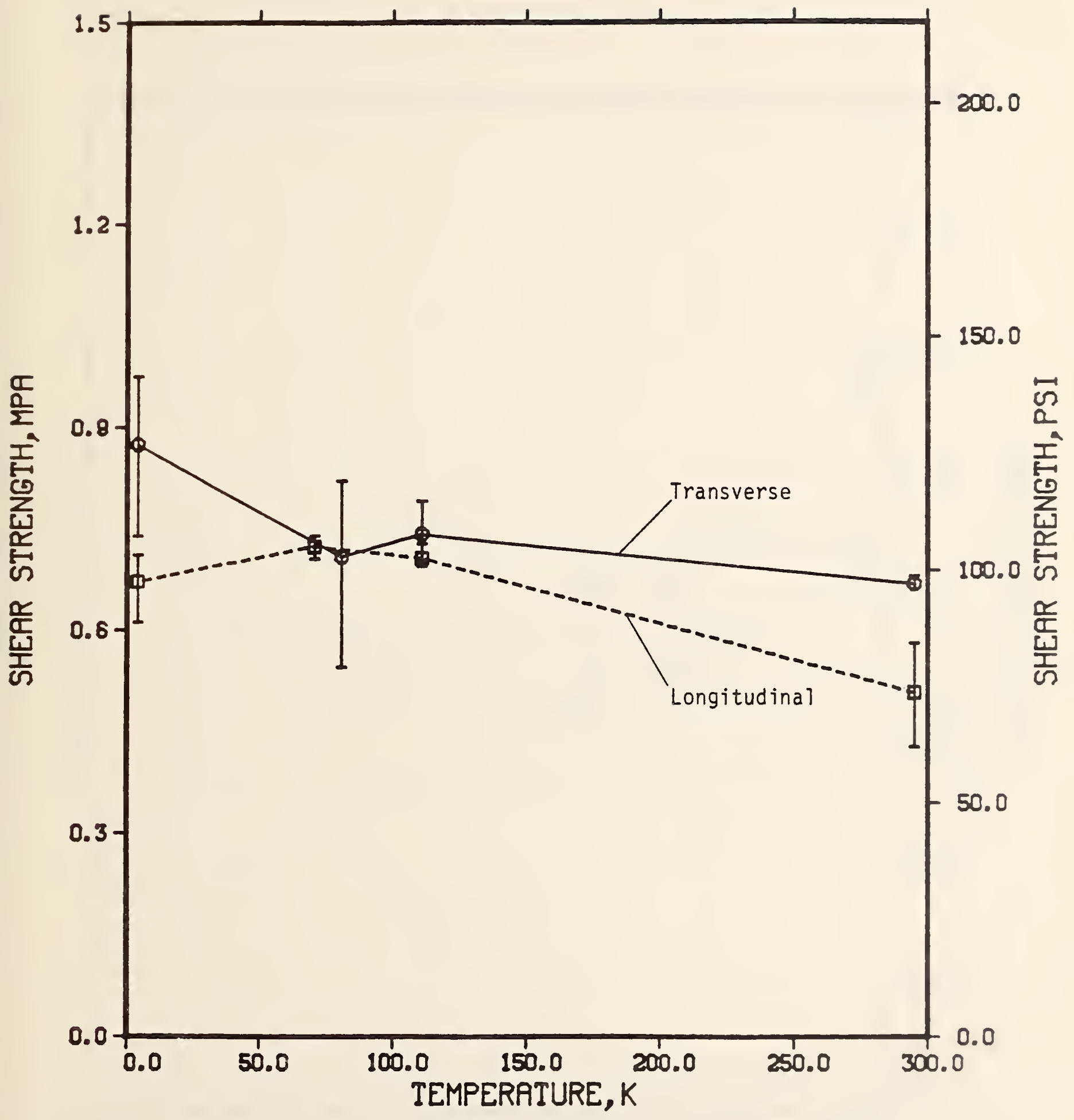

Figure 29. Shear strength versus temperature for a $54-\mathrm{kg} / \mathrm{m}^{3}$ polyurethane foam. 


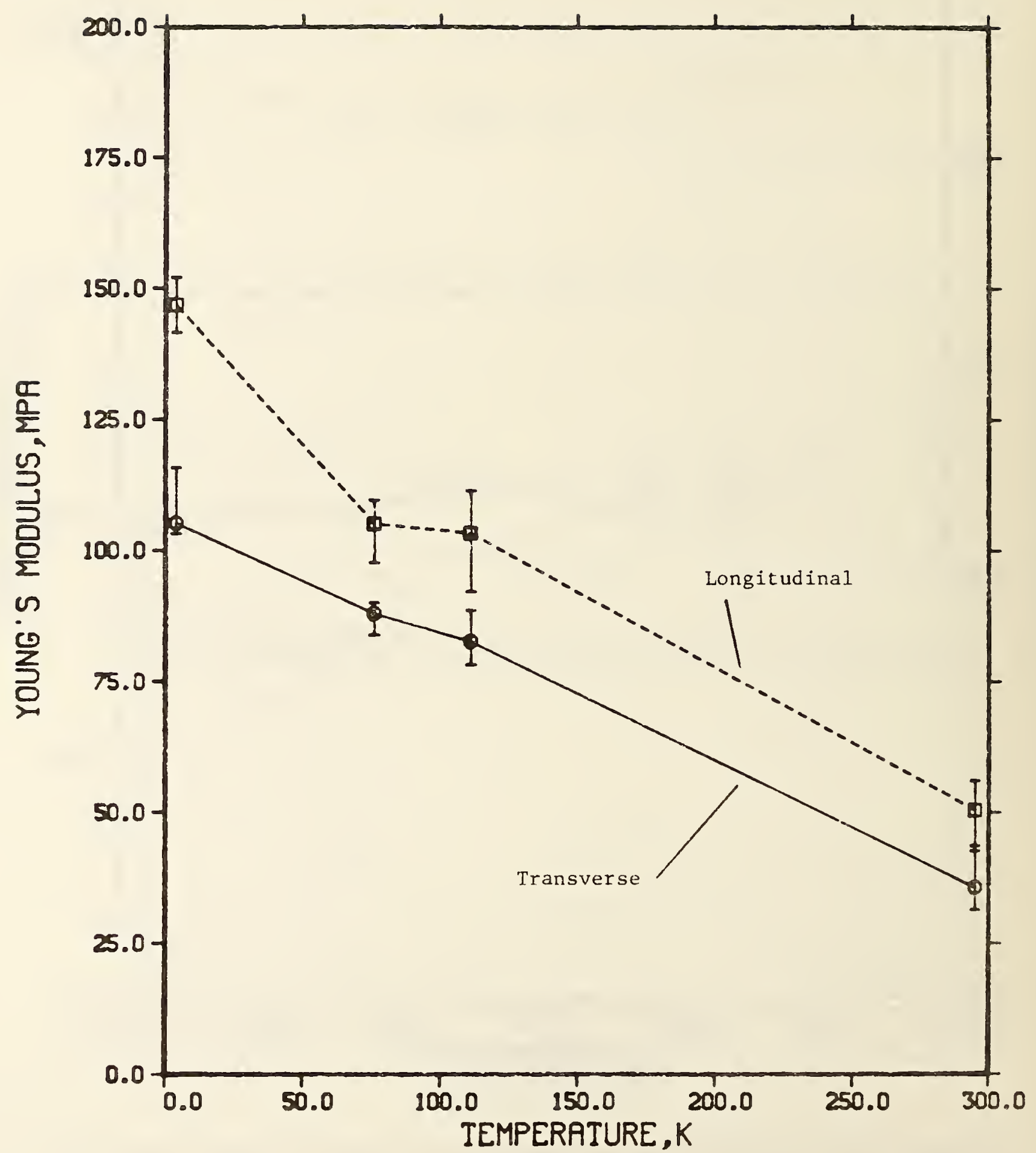

Figure 30. Tensile Young's modulus versus temperature for a $96-\mathrm{kg} / \mathrm{m}^{3}$ polyurethane foam. 


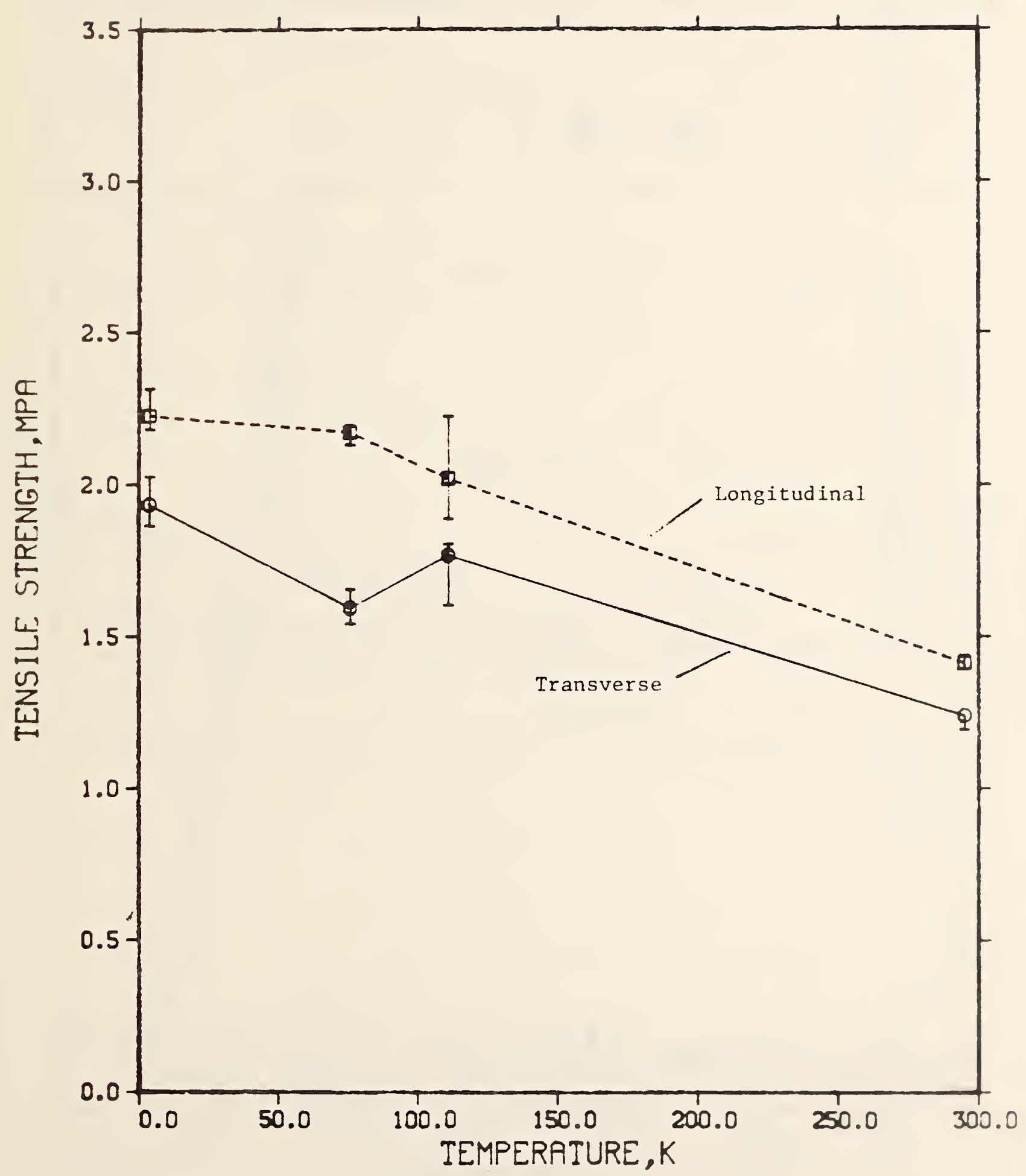

Figure 31. Ultimate tensile strength versus temperature for a $96-\mathrm{kg} / \mathrm{m}^{3}$ polyurethane foam. 

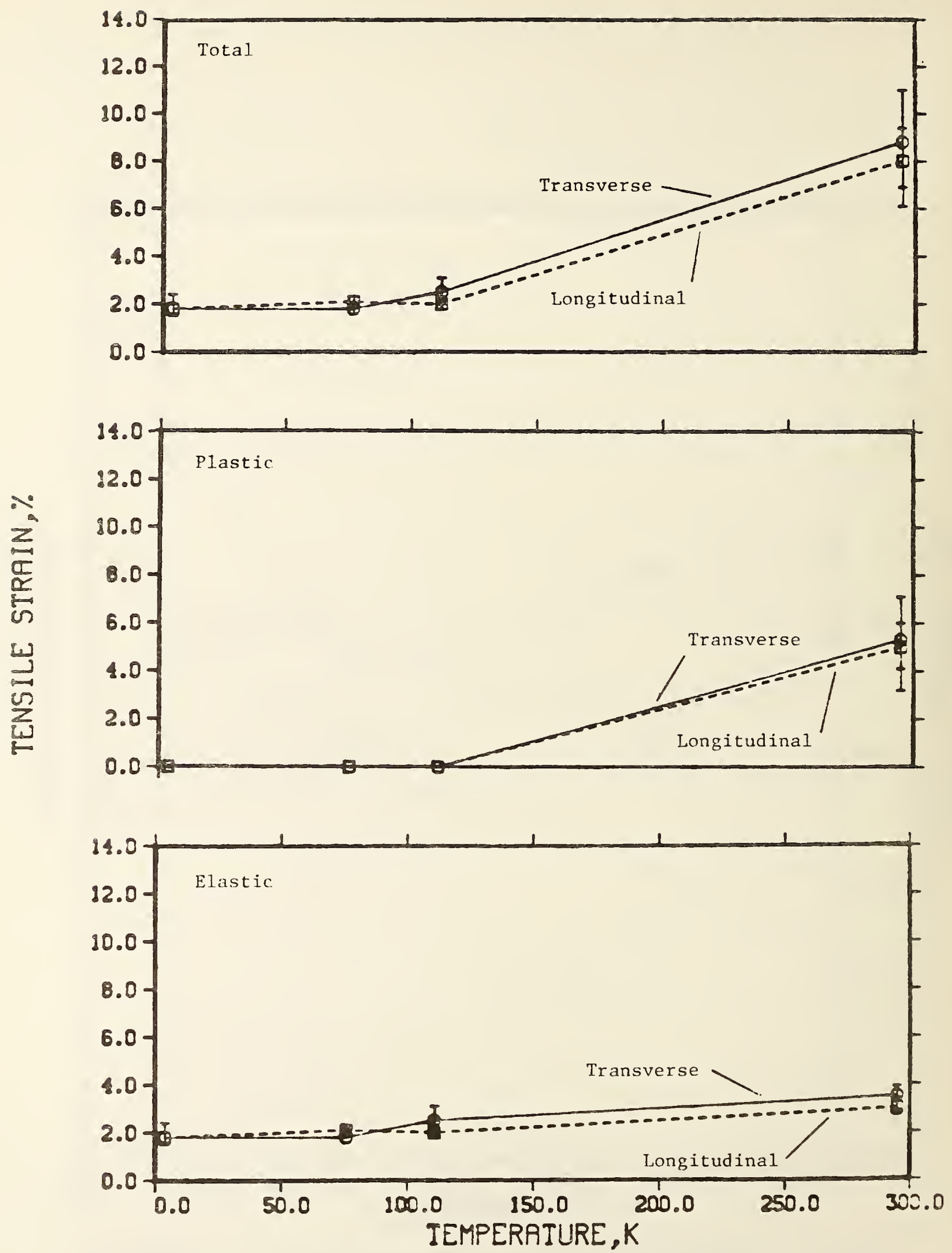

Figure 32. Tensile strain versus temperature for a $96-\mathrm{kg} / \mathrm{m}^{3}$ polyurethane foaln. 


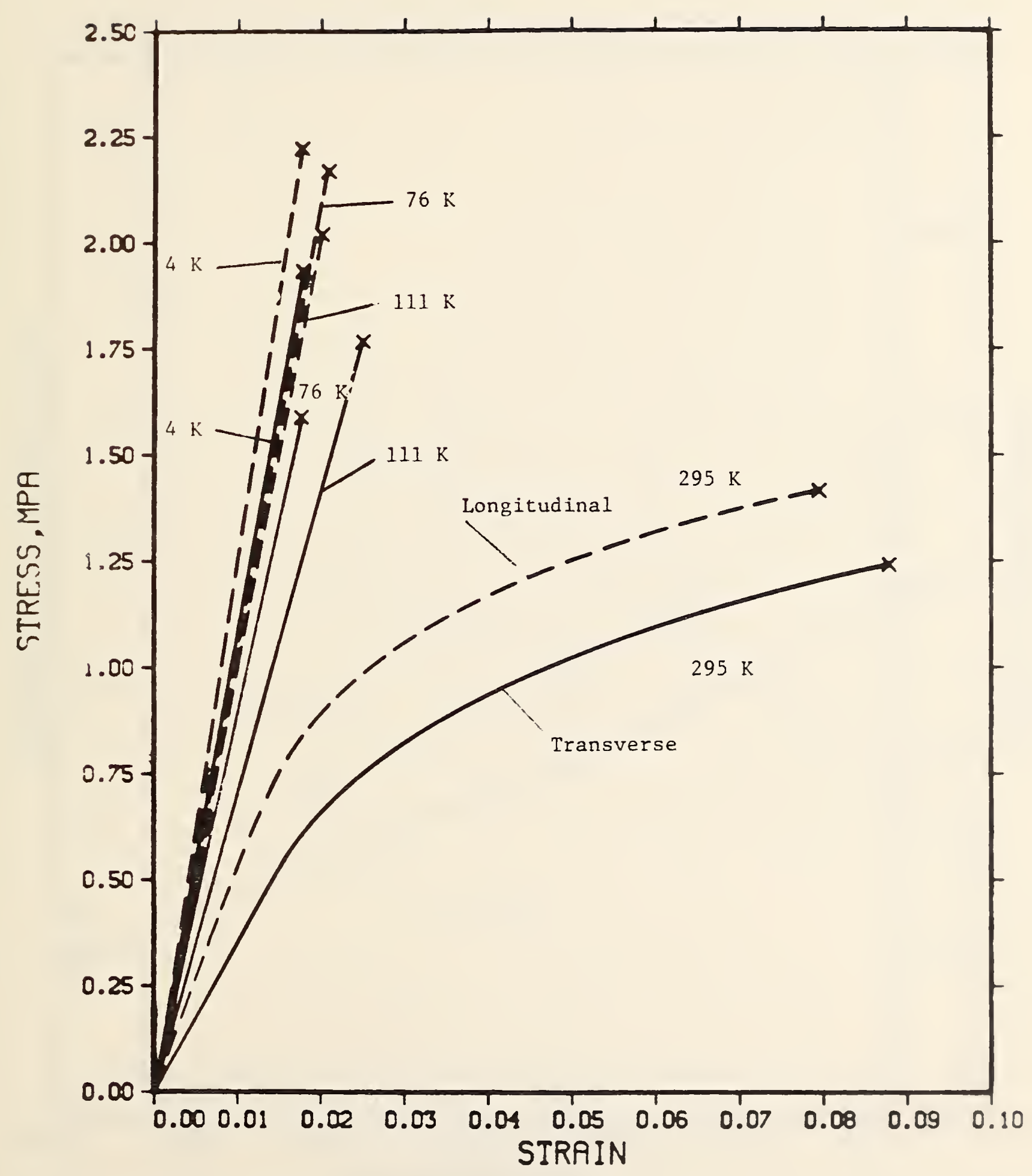

Figure 33. Tensile stress versus strain for a $96-\mathrm{kg} / \mathrm{m}^{3}$ polyurethane foam. 


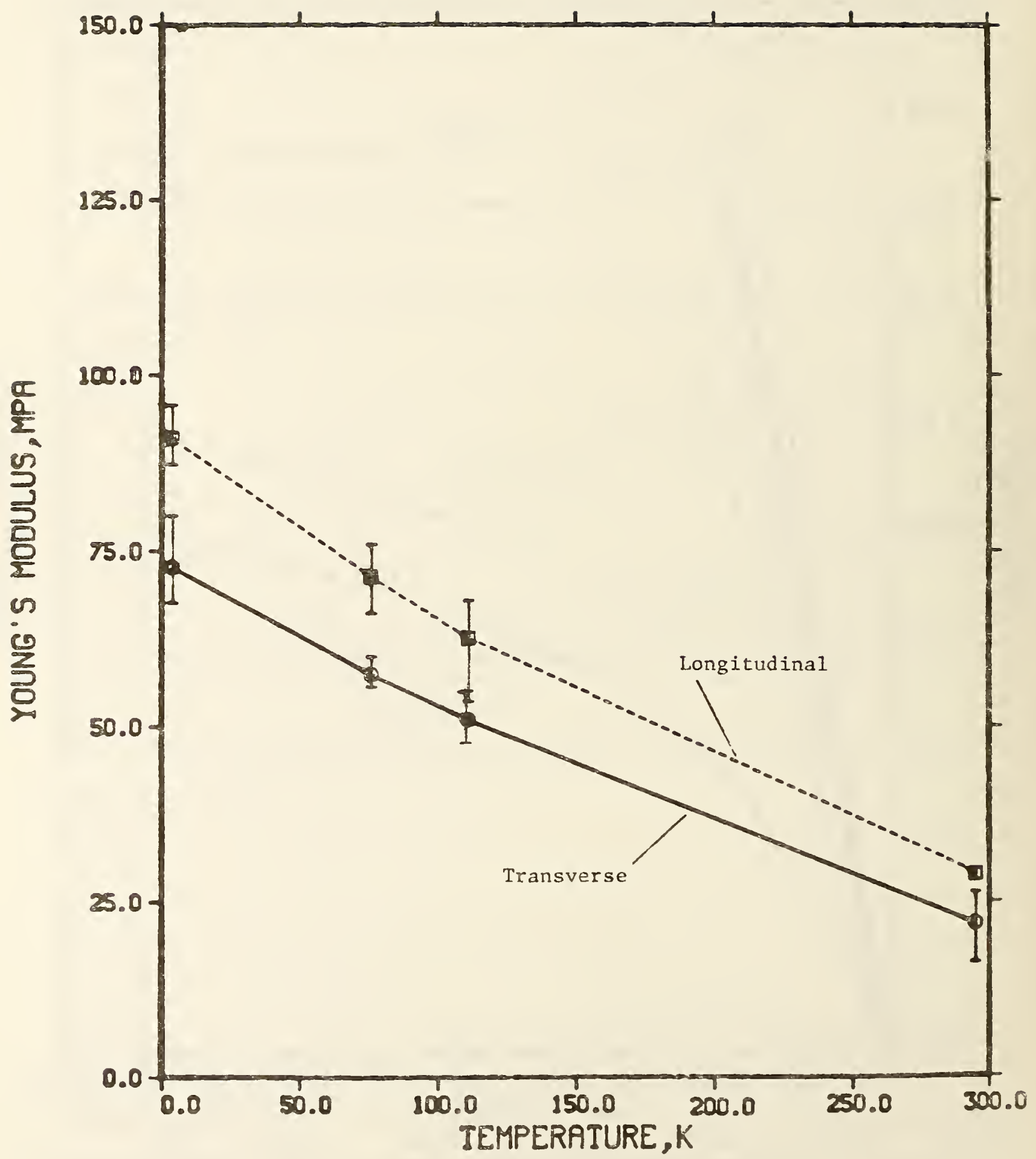

Figure 34. Compressive Young's modulus versus temperature for a $96-\mathrm{kg} / \mathrm{m}^{3}$ polyurethane foam. 


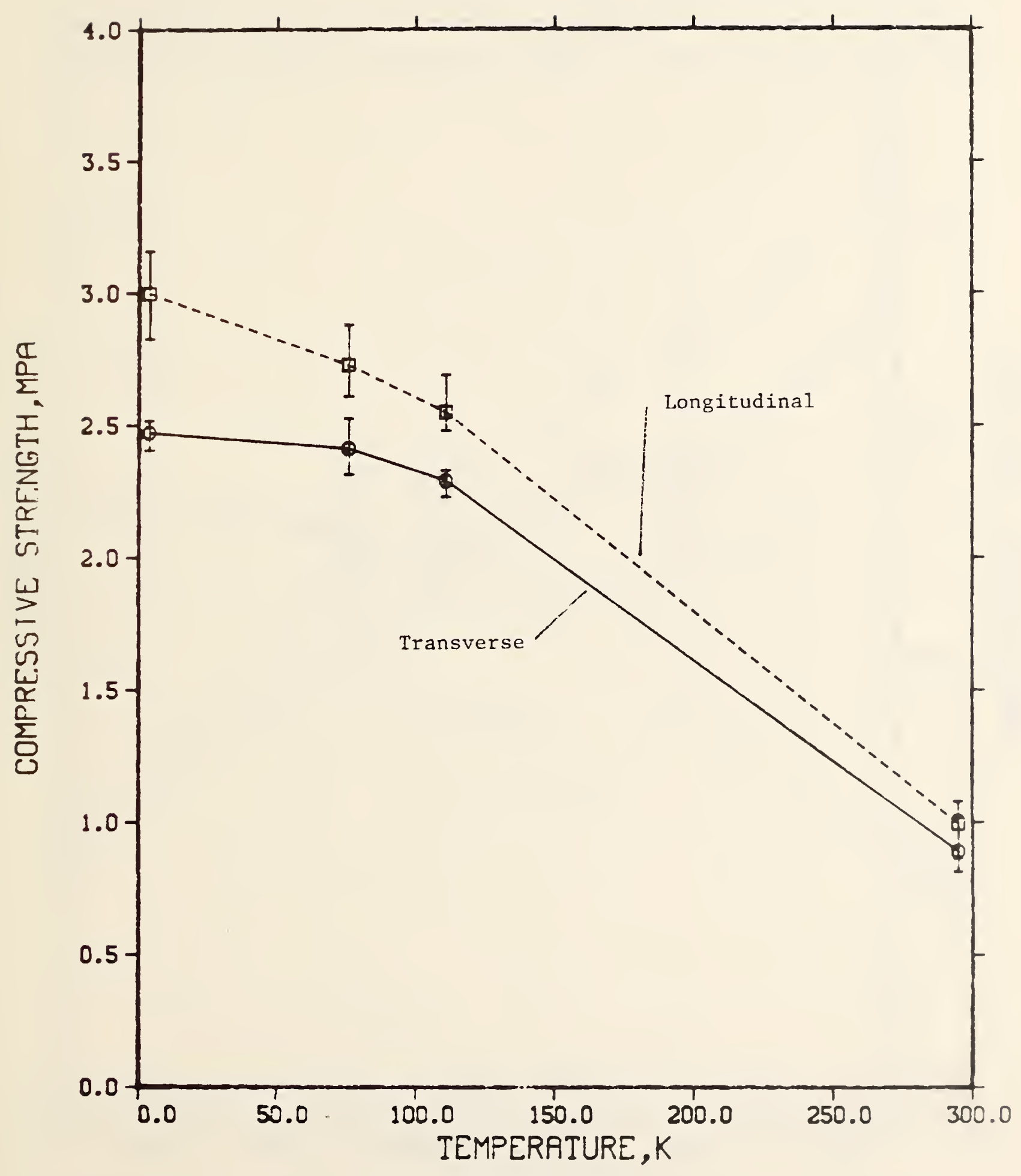

Figure 35. Compressive strength versus temperature for a $96-\mathrm{kg} / \mathrm{m}^{3}$ polyurethane foam. 


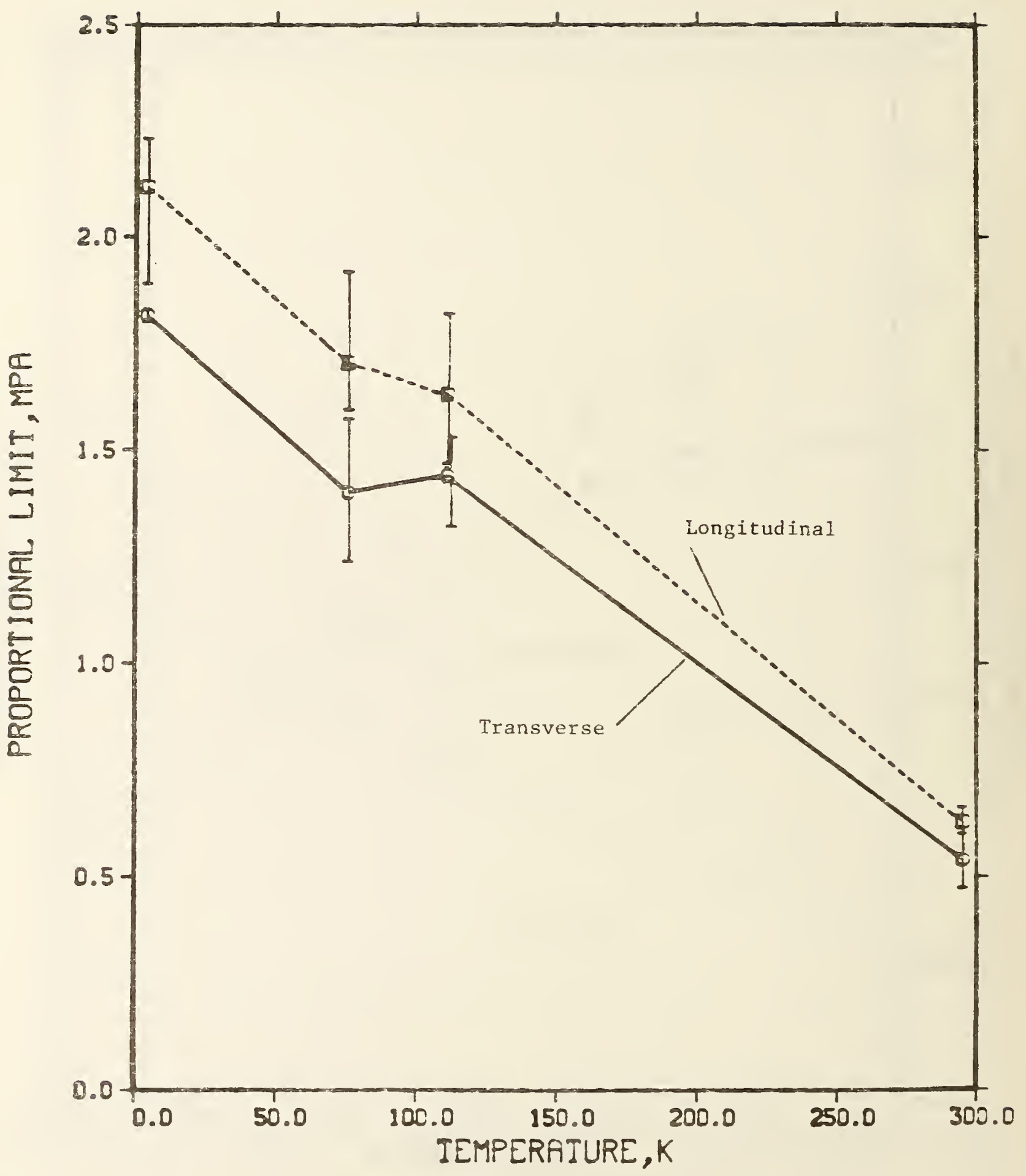

Figure 36. Compressive proportional limit versus temperature for a $96-\mathrm{kg} / \mathrm{m}^{3}$ polyurethane foam. 


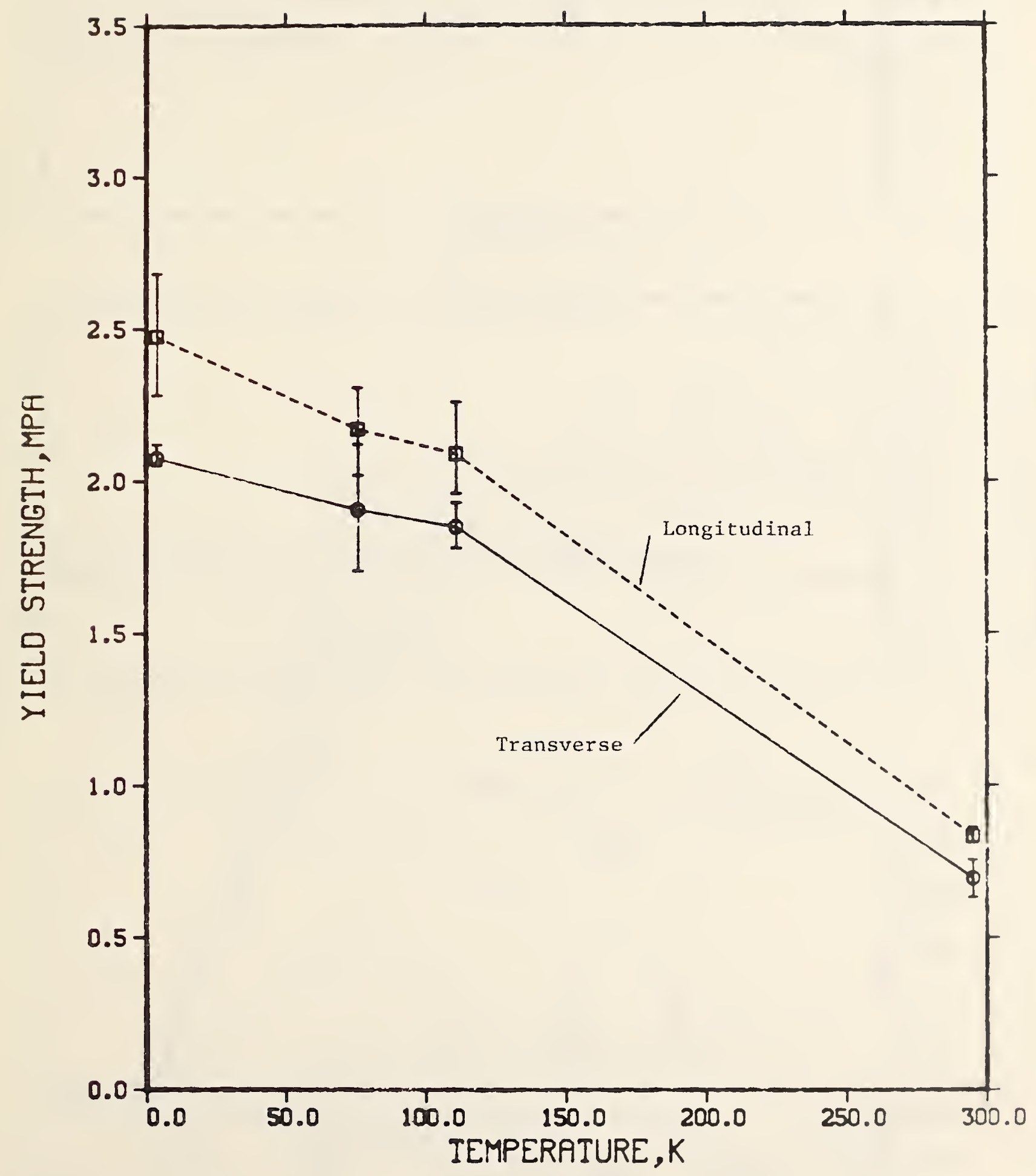

Figure 37. Compressive yield strength versus temperature for a $9.5-\mathrm{kg} / \mathrm{m}^{3}$ polyurethane foam. 

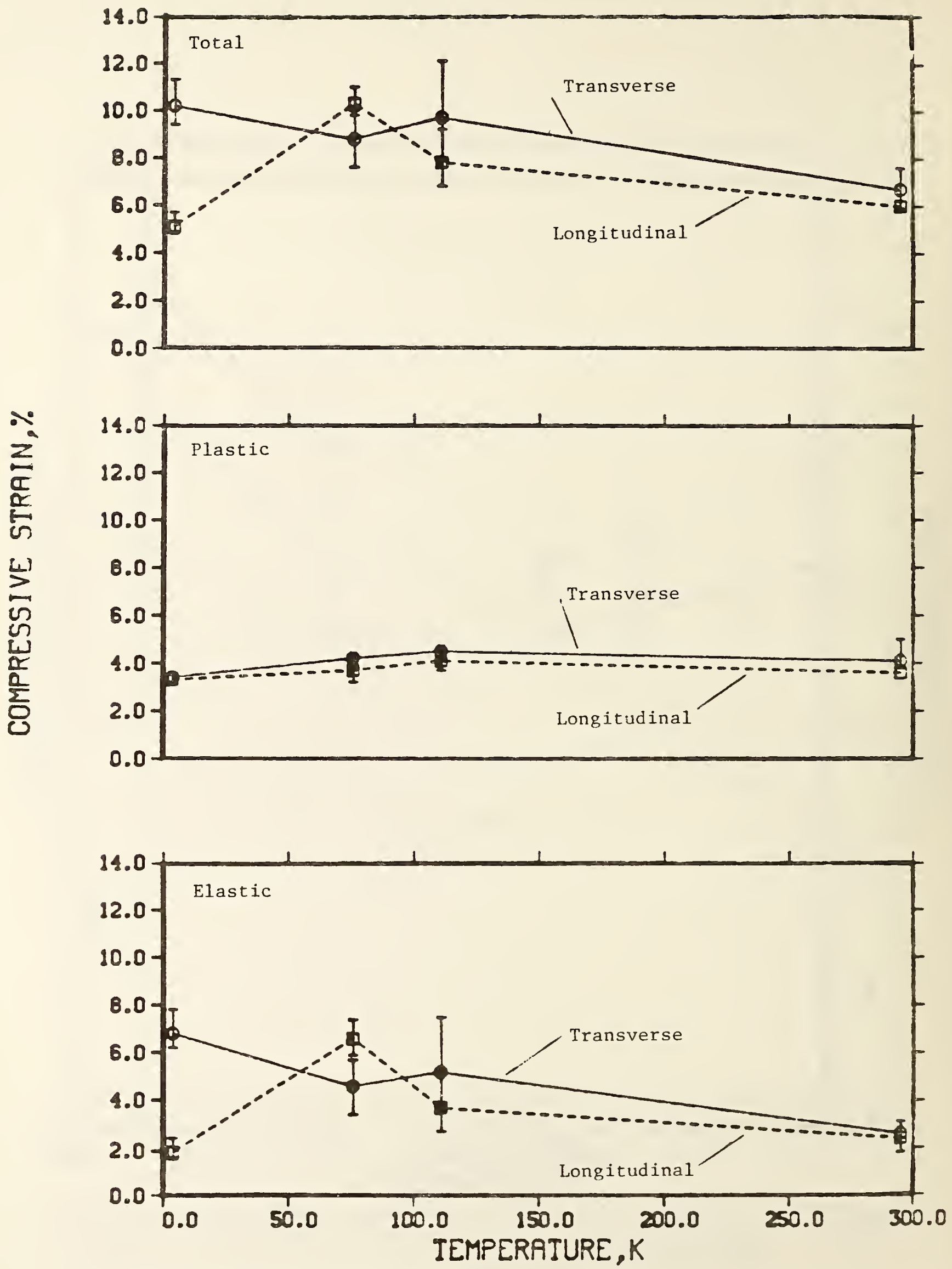

Figure 38. Compressive strain versus temperature for a $96-\mathrm{kg} / \mathrm{m}^{3}$ polyurethane foam. 


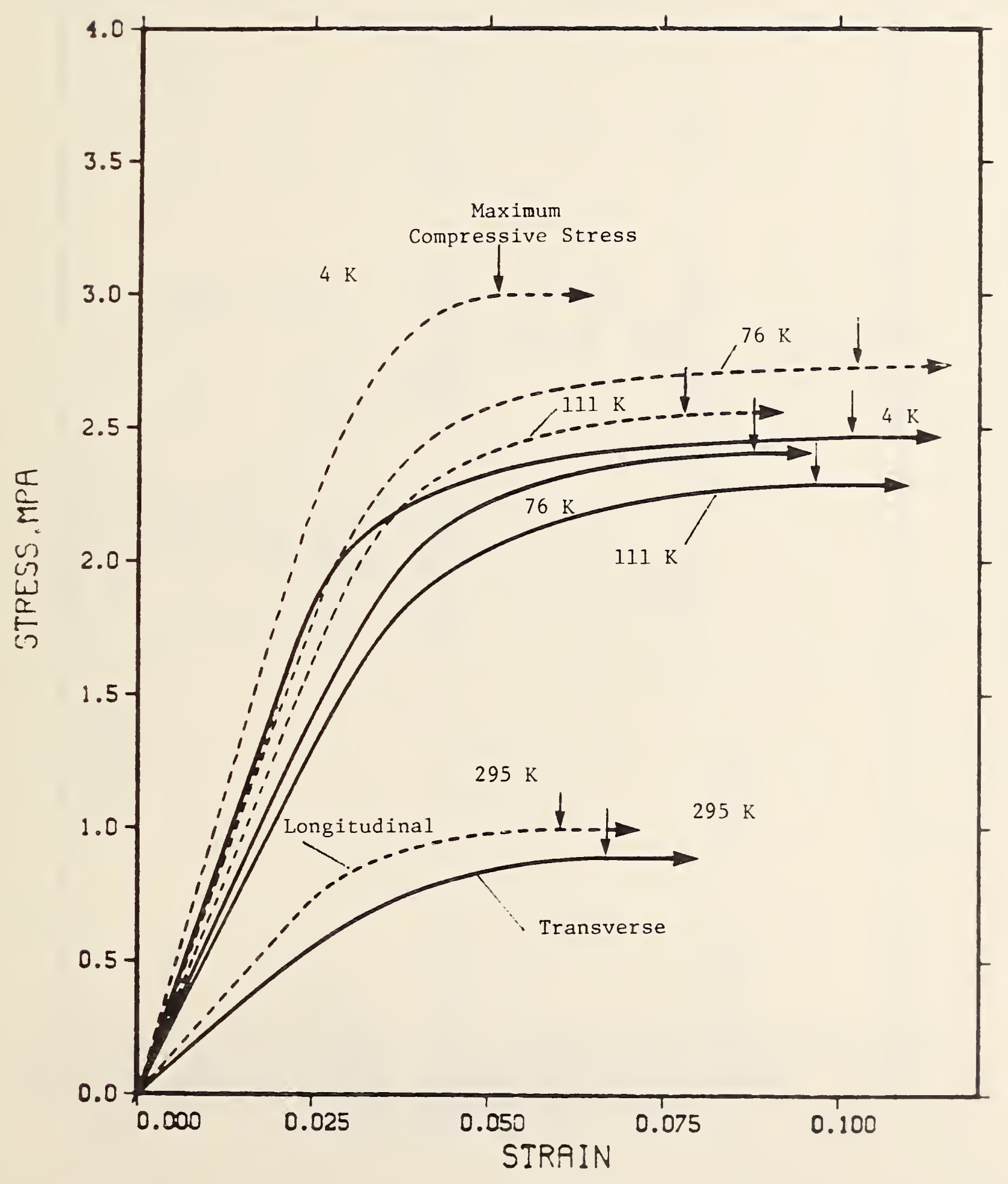

Figure 39. Compressive stress versus strain for a $95-\mathrm{kg} / \mathrm{m}^{3}$ polyurethane foam. 


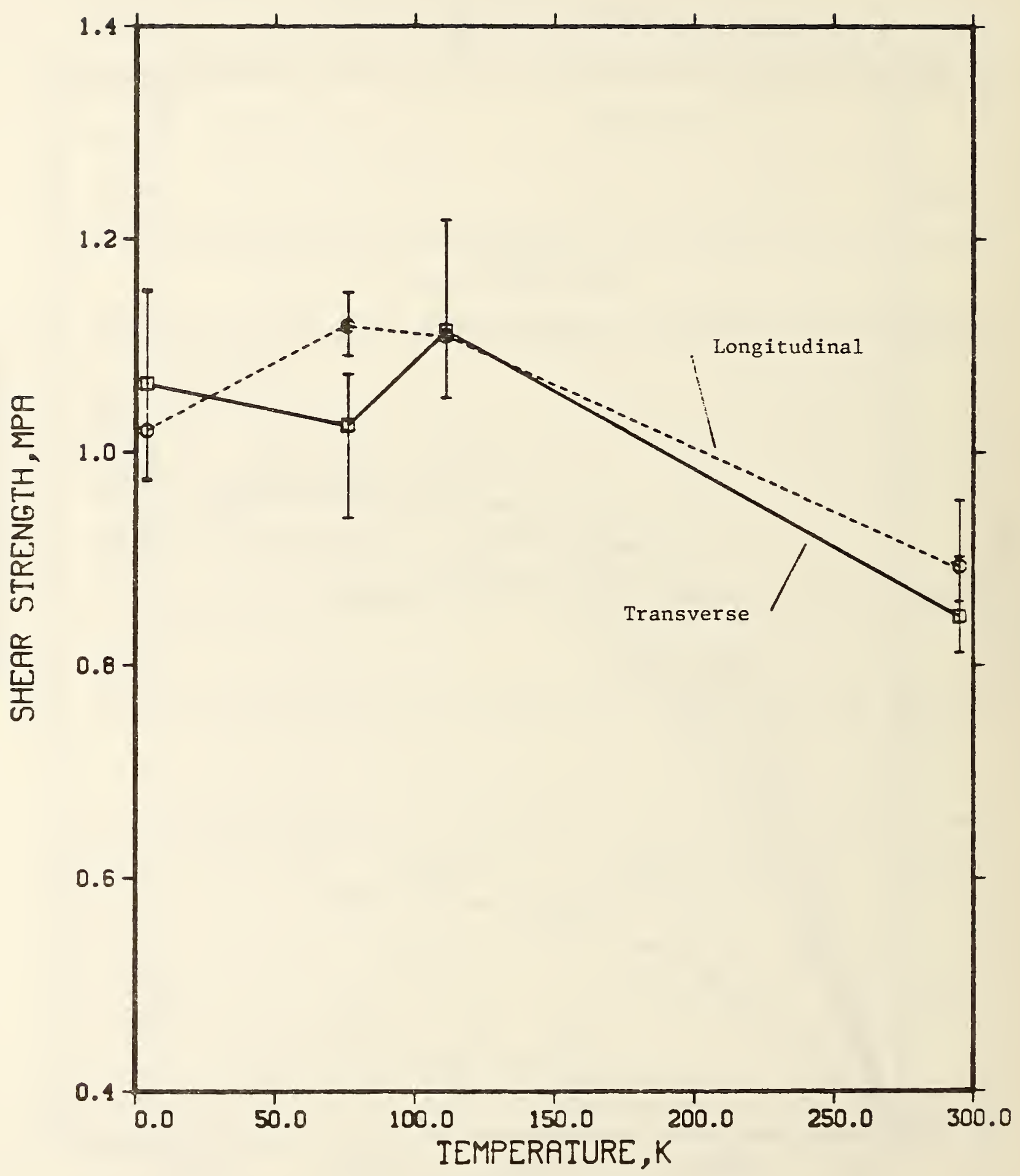

Figure 40. Shear strength versus temperature for a $96-\mathrm{kg} / \mathrm{m}^{3}$ polyurethane foam. 


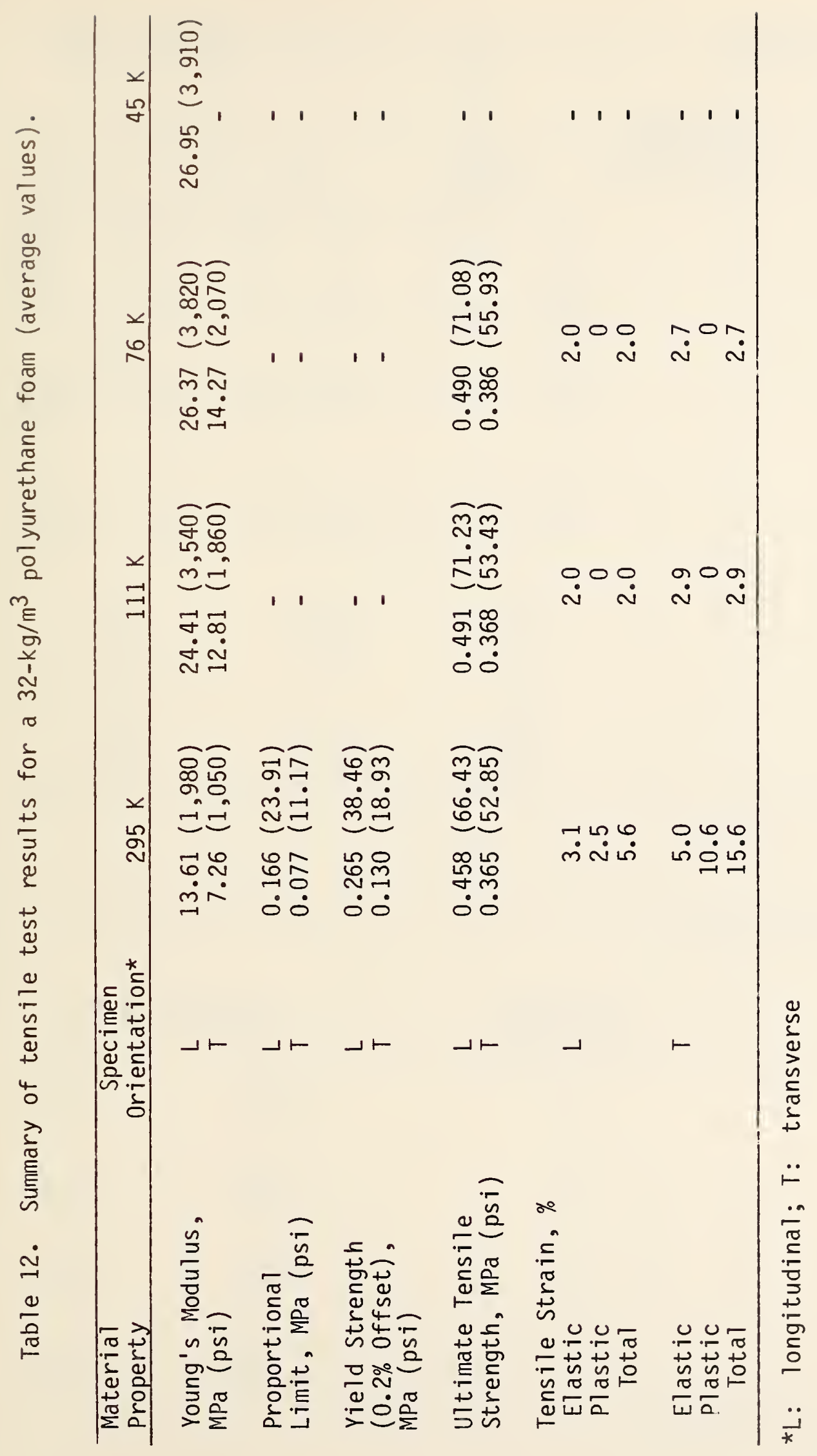


Table 13. Summary of compressive test results for a $32-\mathrm{kg} / \mathrm{m}^{3}$ polyurethane foam (average values).

\begin{tabular}{|c|c|c|c|c|}
\hline $\begin{array}{l}\text { Material } \\
\text { Property }\end{array}$ & $\begin{array}{c}\text { Specimen } \\
\text { Orientation* }\end{array}$ & $295 \mathrm{~K}$ & $111 \mathrm{~K}$ & $76 \mathrm{~K}$ \\
\hline $\begin{array}{l}\text { Young's Modulus, } \\
\text { MPa (psi) }\end{array}$ & $\begin{array}{l}L \\
T\end{array}$ & $\begin{array}{l}8.48(1,230) \\
6.03\left(\begin{array}{rl}(880)\end{array}\right.\end{array}$ & $\begin{array}{r}14.88(2,160) \\
6.69(970)\end{array}$ & $\begin{array}{r}13.26(1,920) \\
6.40(930)\end{array}$ \\
\hline $\begin{array}{l}\text { Proportional } \\
\text { Limit, } \mathrm{MPa} \text { (psi) }\end{array}$ & $\begin{array}{l}\mathrm{L} \\
\mathrm{T}\end{array}$ & $\begin{array}{l}0.067(9.70) \\
0.073(10.63)\end{array}$ & $\begin{array}{l}0.079(11.47) \\
0.150(21.75)\end{array}$ & $\begin{array}{ll}0.152 & (22.03) \\
0.118 & (17.14)\end{array}$ \\
\hline $\begin{array}{l}\text { Yield Strength } \\
(0.2 \% \text { offset), } \\
\mathrm{MPa} \text { (psi) }\end{array}$ & $\begin{array}{l}L \\
T\end{array}$ & $\begin{array}{l}0.114(16.57) \\
0.109(15.80)\end{array}$ & $\begin{array}{l}0.146(21.15) \\
0.179(26.04)\end{array}$ & $\begin{array}{ll}0.204 & (29.60) \\
0.172 & (24.98)\end{array}$ \\
\hline $\begin{array}{l}\text { Maximum Compressive } \\
\text { Strength, MPa (psi) }\end{array}$ & $\begin{array}{l}\mathrm{L} \\
\mathrm{T}\end{array}$ & $\begin{array}{l}0.287(41.62) \\
0.218(31.60)\end{array}$ & $\begin{array}{ll}0.311 & (45.12) \\
0.247 & (35.91)\end{array}$ & $\begin{array}{ll}0.338 & (49.02) \\
0.227 & (32.93)\end{array}$ \\
\hline $\begin{array}{l}\text { Compressive Strain, } \% \\
\text { Elastic } \\
\text { Plastic } \\
\text { Total }\end{array}$ & $L$ & $\begin{array}{l}3.3 \\
4.4 \\
7.7\end{array}$ & $\begin{array}{r}1.9 \\
12.4 \\
14.3\end{array}$ & $\begin{array}{r}2.5 \\
9.4 \\
11.9\end{array}$ \\
\hline $\begin{array}{r}\text { Elastic } \\
\text { Plastic } \\
\text { Total }\end{array}$ & $T$ & $\begin{array}{l}3.0 \\
5.4 \\
8.4\end{array}$ & $\begin{array}{r}3.4 \\
10.5 \\
13.9\end{array}$ & $\begin{array}{r}3.3 \\
15.2 \\
18.5\end{array}$ \\
\hline
\end{tabular}

*L: longitudinal; $T$ : transverse

Table 14. Summary of shear strength test results for a $32-\mathrm{kg} / \mathrm{m}^{3}$ polyurethane foam (average values).

\begin{tabular}{|c|c|c|c|}
\hline \multirow{2}{*}{$\begin{array}{c}\text { Test } \\
\text { Temperature, } \mathrm{K}\end{array}$} & \multirow{2}{*}{$\begin{array}{c}\text { Specimen } \\
\text { Orientation* }\end{array}$} & \multicolumn{2}{|c|}{ Shear Strength } \\
\hline & & $\mathrm{MPa}$ & $\mathrm{psi}$ \\
\hline 295 & $\begin{array}{l}L \\
T\end{array}$ & $\begin{array}{l}0.217 \\
0.217\end{array}$ & $\begin{array}{l}31.47 \\
31.43\end{array}$ \\
\hline 111 & $\frac{L}{T}$ & $\begin{array}{l}0.266 \\
0.219\end{array}$ & $\begin{array}{l}38.62 \\
31.74\end{array}$ \\
\hline 76 & $\begin{array}{l}L \\
T\end{array}$ & $\begin{array}{l}0.242 \\
0.225\end{array}$ & $\begin{array}{l}35.14 \\
32.65\end{array}$ \\
\hline $76^{\star \star *}$ & $\begin{array}{l}\mathrm{L} \\
\mathrm{T}\end{array}$ & $\begin{array}{l}0.241 \\
0.216\end{array}$ & $\begin{array}{l}34.95 \\
31.39\end{array}$ \\
\hline
\end{tabular}

*L: longitudinal; $T$ : transverse

**Test conducted in $\mathrm{LN}_{2}$. 


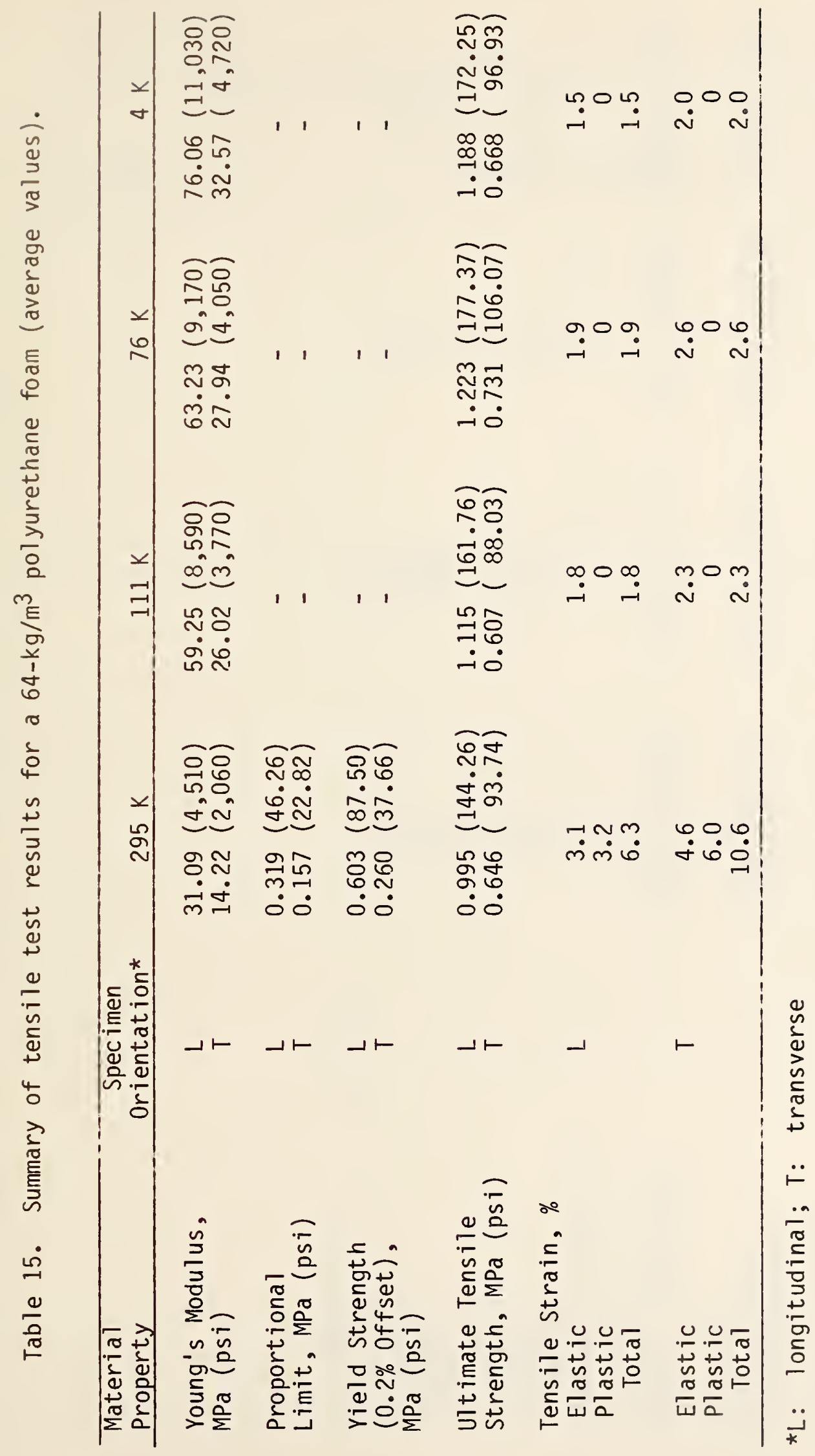




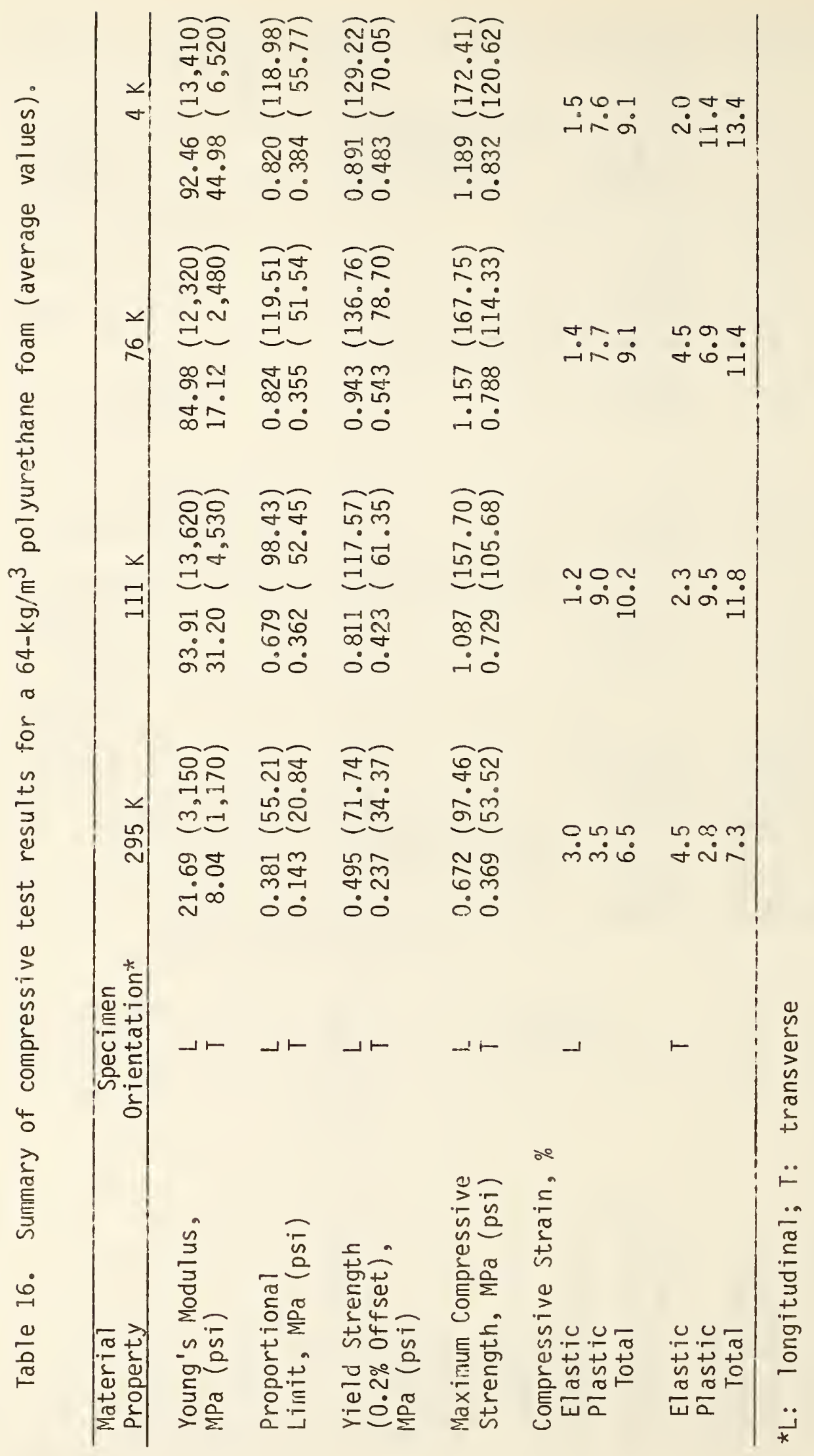


Table 17. Summary of shear strength test results for a $64-\mathrm{kg} / \mathrm{m}^{3}$ polyurethane foam (average values).

\begin{tabular}{cccr}
\hline Test & Specimen & Orientation* & \multicolumn{2}{c}{ Shear Strength } \\
\cline { 5 - 5 } Temperature, $K$ & & MPa & psi \\
\hline \multirow{2}{*}{295} & L & 0.508 & 73.57 \\
& T & 0.668 & 96.92 \\
& L & 0.706 & 102.41 \\
76 & T & 0.741 & 107.47 \\
& L & 0.724 & 104.91 \\
4 & T & 0.709 & 102.75 \\
& L & 0.672 & 97.36 \\
& T & 0.874 & 126.74 \\
\hline
\end{tabular}

*L: longitudinal; $T$ : transverse 


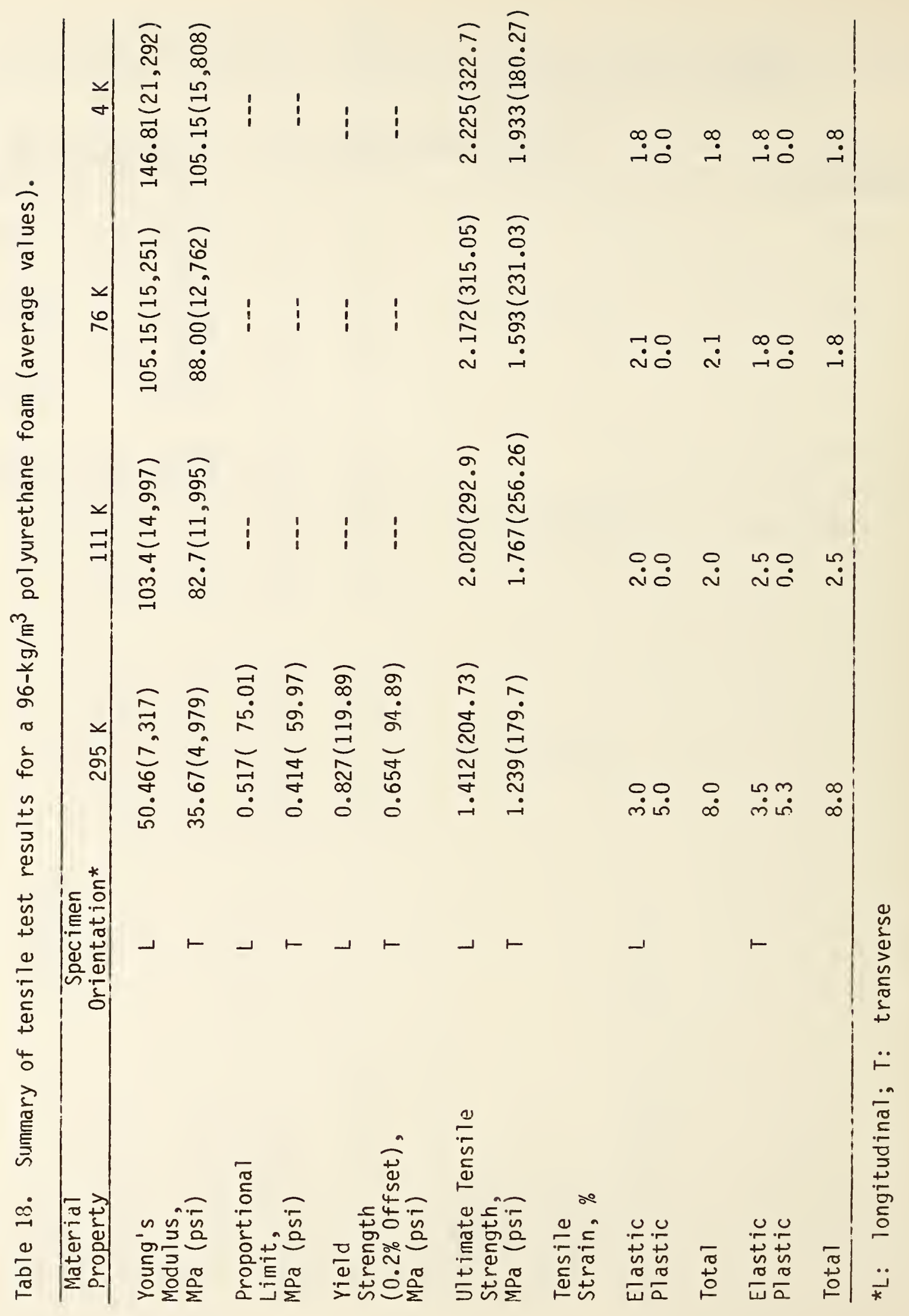


Table 20. Summary of shear strength test results for a $96-\mathrm{kg} / \mathrm{m}^{3}$ polyurethane foam (average values).

\begin{tabular}{cccc}
\hline $\begin{array}{c}\text { Test } \\
\text { Temperature, } K\end{array}$ & Specimen & Orientation* & Shear Strength \\
\hline \multirow{2}{*}{295} & $\mathrm{~L}$ & 0.846 & 122.70 \\
& $\mathrm{~T}$ & 0.893 & 129.54 \\
111 & $\mathrm{~T}$ & 1.114 & 161.58 \\
& $\mathrm{~L}$ & 1.109 & 160.85 \\
76 & $\mathrm{~T}$ & 1.025 & 148.59 \\
& $\mathrm{~L}$ & 1.118 & 162.15 \\
\multirow{2}{*}{4} & $\mathrm{~T}$ & 1.064 & 154.38 \\
& $\mathrm{~L}$ & 1.020 & 147.99 \\
\hline
\end{tabular}

*L: longitudinal; $T$ : transverse

Discussion of Results and Modeling

Thermal Conductivity - Heat is conducted through a foamed material via solid and gaseous conduction, by radiation, and by convection. Skochdopole (1961) has shown that convective heat transfer will not occur in cells whose dimensions are less than $3 \mathrm{~mm}$. The cells of undamaged polyurethane foam with density of $32 \mathrm{~kg} / \mathrm{m}^{3}$ or greater are at ieast a factor of three smaller than this threshold size. The foams studied here have cell dimensions smaller than $0.5 \mathrm{~mm}$ (see table 1). The convective mode will therefore be ignored in the remaining discussion. It is important to keep in mind that if cracks develop in the foam, either due to thermal or mechanical stresses or debonding, convection can become a dominant mode of heat transfer.

Radiant heat flow through foam insulation is due to both iransmission and to absorption and reradiation. Resins used for making foams are partially transparent in the 2 to $30 \mu \mathrm{m}$ range of wavelengths (Skochdopole, 1961). Sections associated with thermal insulations are normally optically thick (thickness 〉 photon !nean free path), however, so that direct transmission will 
be small. The effective conductivity due to radiant heat transfer $\left(k_{r}\right)$ can be estimated by

$$
k_{r}=4 \text { oee } T^{3}
$$

where $\sigma$ is the Stefan-Boltzman constant $\left(5.67 \times 10^{-8} \mathrm{~W} \cdot \mathrm{m}^{-2} \mathrm{~K}^{-4}\right)$, e is the emissivity of foam, $\ell$ is the cell dimension parallel to heat flow, and $T$ is the temperature of the warmer side of the specimen.

Solid conduction $\left(k_{s}\right)$ takes place through the cell walls and membranes of the foam. Since PU resins are disordered (noncrystalline) insulators, heat is transported by lattice vibrations (phonons) and is nearly a linear function of temperature. The relationships describing the solid conductivity of the foams tested here are

$$
\begin{aligned}
k_{s} & =0.90+0.0190 \mathrm{~T} & & \text { for PU32, } \\
k_{s} & =3.08+0.0172 \mathrm{~T} & & \text { for PU64, } \\
\text { and } k_{s} & =4.36+0.0278 \mathrm{~T} & & \text { for PU96. }
\end{aligned}
$$

Temperature is in kelvin and thermal conductivity in $\mathrm{mW} / \mathrm{m} \cdot \mathrm{K}$. The steric factors, which arise due to elongation of cell axes parallel to the direction of heat flow, are included in these relationships by virtue of their experimental basis.

The remaining mode of heat transfer is conduction through the gas $\left(\mathrm{k}_{\mathrm{g}}\right)$ occupying the foam cells. Figure 41 indicates the conductivity of gases sometimes found in insulating foams. When a mixture of gases is present, $\mathrm{kg}$ can be estimated by

$$
k_{g}=k_{\text {mixture }}=\sum_{i=1}^{n} x_{i} k_{i}
$$




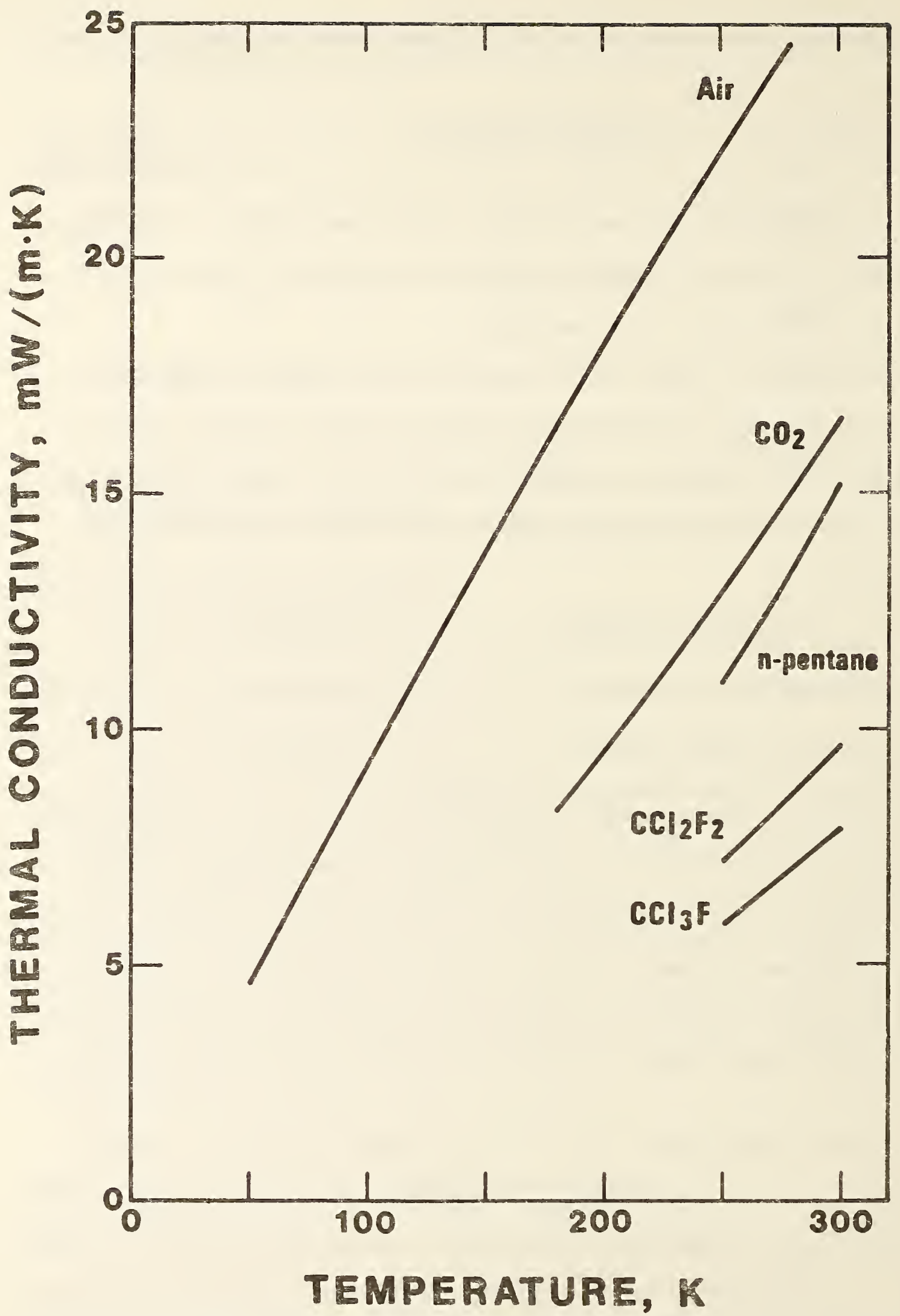

Figure 41. Thermal conductivity as a function of temperature for gases commonly found in polyurethane foams (Touloukian, Liley, and Saxena, 1970). 
where thermal conductivities of the individual species are given by $k_{i}, X_{i}$ represents the corresponding mole fraction, and $n$ is the number of species present. The $k_{j}$ are temperature dependent and, as seen in figure 41 , are nearly Tinear functions of temperature. The gases present in PU32, PU64, and PU96 are $\mathrm{CC}_{3} \mathrm{~F}$ and air. Their conductivities can be approximated by (Touloukian, Liley, and Saxena, 1970)

$$
\begin{gathered}
k_{\mathrm{CCl}_{3} F}=-4.1+0.04 \mathrm{~T}, 250 \leq \mathrm{T} \leq 300 \mathrm{~K} \\
k_{\text {air }}=-0.661+0.103 \mathrm{~T}-0.469 \times 10^{-4} \mathrm{~T}^{2}, 100 \leq \mathrm{T} \leq 350 \mathrm{~K}
\end{gathered}
$$

in units of $\mathrm{mW} / \mathrm{m} \cdot \mathrm{K}$. Total gas conduction is given by

$$
k_{g}=X_{C_{C} \ell_{3} F} k_{C C \ell_{3} F}+\left(1-X_{C C \ell_{3} F}\right) k_{\text {air }}
$$

Harding (1964) indicates that the values predicted by this simple molar mixing approach tend to be slightly higher than those computed using kinetic theory ( Tsederberg, 1965).

Although it is not rigorously correct to add the modes of heat transfer (they are not independent of one another), the total apparent conductivity $\left(k_{T}\right)$ obtained using this approximation is acceptable for polyurethane foams (Gorring and Churchill, 1961).

$$
k_{T}=k_{g}+k_{s}+k_{r}
$$

For temperatures near ambient, only gases exist in the cells and $k_{T}$ can be estimated using eqs $(4),(5),(8)$, and (9) when $\mathrm{X}_{\mathrm{CC}_{3} \mathrm{~F}}$ is known. If partial pressures are also known at $T_{j}$, eqs (10) and (11) can be used to determine $\mathrm{X}_{\mathrm{CC}_{3} \mathrm{~F}}$. The ratio of partial pressure to absolute temperature (eq 10) is constant for each species to the extent that they approximate ideal gases.

$$
\begin{aligned}
& P_{C C \ell_{3} F, T}=P_{C C \ell_{3} F, T_{i}}(T) / T_{i}, T>T_{C} \\
& P_{\text {air, } T}=P_{\text {air, }, T_{i}}(T) / T_{i}, T>100 \mathrm{~K}
\end{aligned}
$$


and

$$
X_{C C \ell_{3} F, T}=P_{C C \ell_{3} F, T} /\left(P_{C \ell_{3} F, T}+P_{\text {air }, T}\right)
$$

At temperatures less than or equal to $\mathrm{T}_{C}$ condensation of $\mathrm{CC}_{3} \mathrm{~F}$ occurs and the partial pressure of $\mathrm{CC}_{3} \mathrm{~F}$ is given by

$$
P_{v}=P_{C C \varepsilon_{3} F}=8.0875 \times 10^{6} / \exp (3340.4 / T), T \leq T_{C}
$$

where $T$ is in $K$ and pressure is in $\mathrm{KPa}$ (the saturated vapor pressure is more accurately given by a complex relationship in Du Pont, 1979). The temperature of initial liquid vapor equilibrium for $\mathrm{CCl}_{3} F\left(T_{C}\right)$ is indicated by the inflection in thermal conductivity at $T_{C}=278 \mathrm{~K}$, $=275 \mathrm{~K}$, and $=245 \mathrm{~K}$ for PU32, PU64, and PU96, respectively (fig. 8).

The equations given above and the thermal conductivity data were used to independently determine the cellular gas content of PU32, PU64, and PU96 (table 5). Results of the calculations are shown in table 21. The components of the total apparent thermal conductivity were calculated using the relationships given here and are also shown in this table. Comparison of the computed conductivities to the experimentally observed values indicates that the relationships for $k_{s}, k_{r}$, and $k_{g}$ apply quite well to PU32, PU64, and PU96.

Thermal expansion - Little low-temperature data exists in the literature for Delta $L / L$ or CTE of polyurethane. Materials which have been tested are generally characterized by a nominal density and sometimes a tradename. Comparison of the current values to the existing data base indicates that Delta $\mathrm{L} / \mathrm{L}$ at $105 \mathrm{~K}$ for PU32, PU64, and PU96 fall near the median with a band of approximately $\pm 20 \%$ needed to include all of the literature values. A more quantitative comparison is not justified considering the variation of materials involved.

The diagram shown in figure 42 indicates the parameters that can affect the expansion characteristics. Although not indicated in the diagram, none of the 


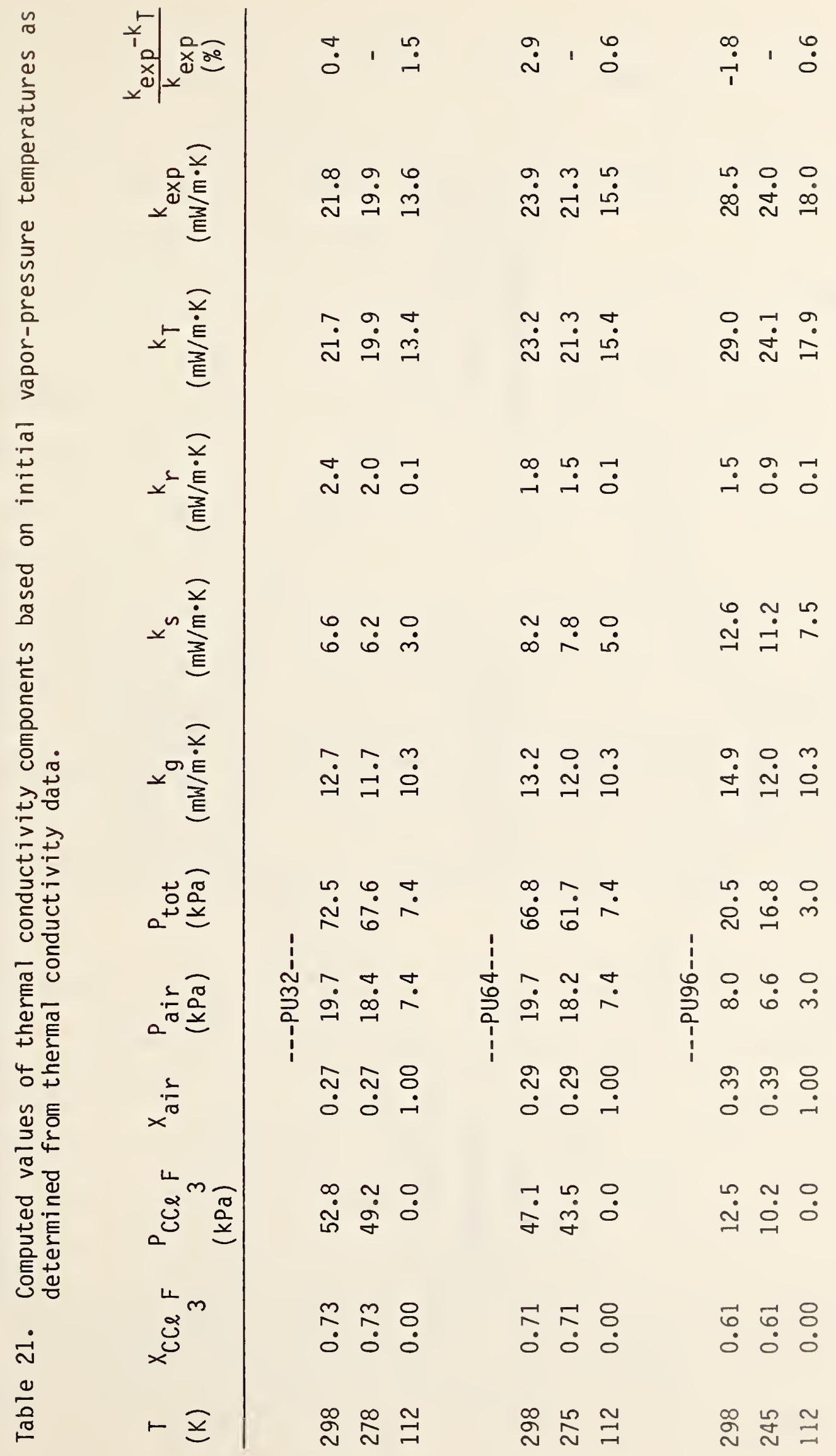




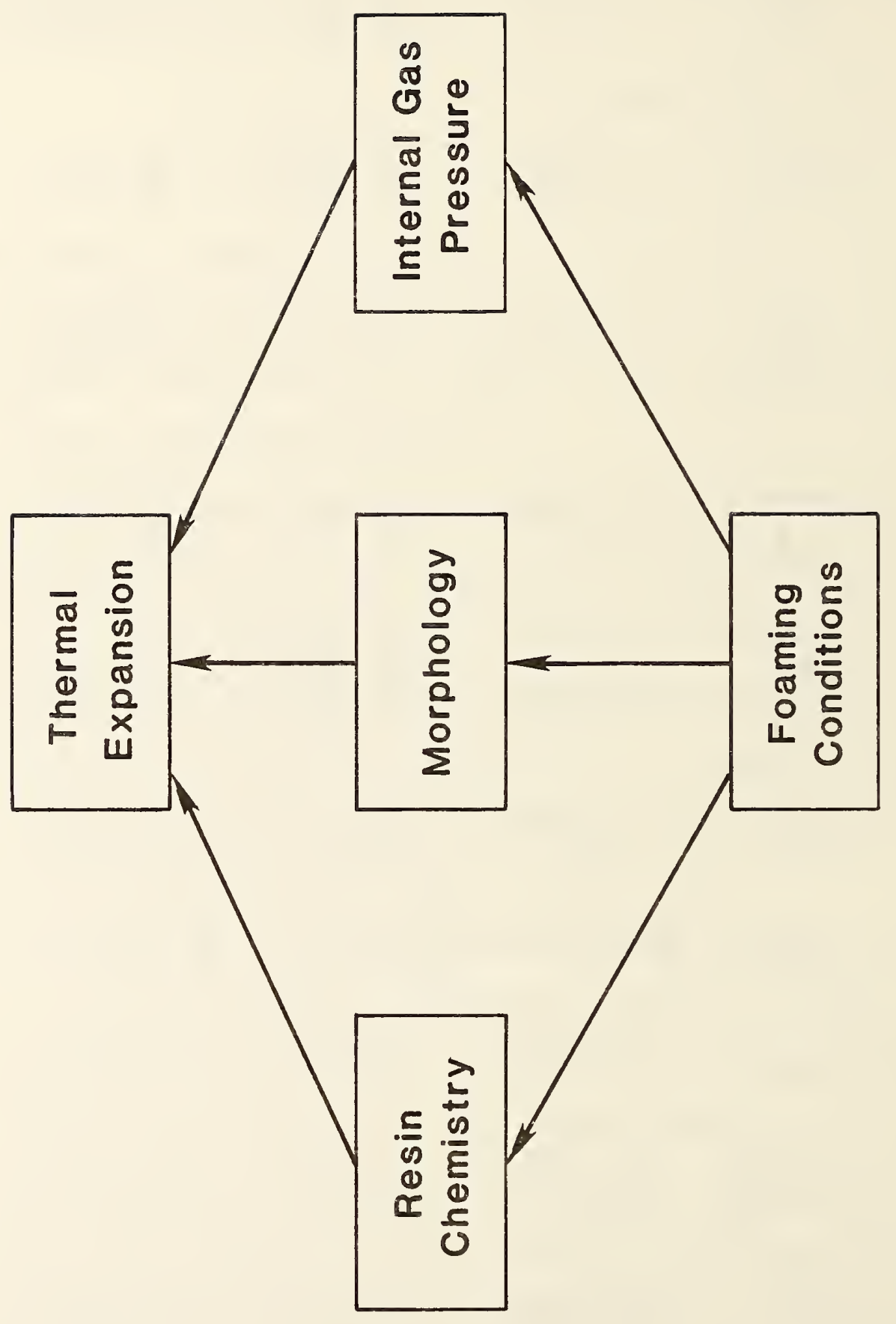

产

扸

음

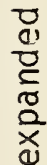

4

ธิ

苋

范

造

昰

ह

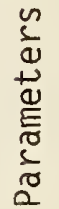

ํㅏㅁ

宊 
parameters are independent of one another, e.g., the blowing agent will dissolve in the resin to some extent and will alter the resin chemistry. Viscosity will also be affected by dissolved gases and will, in turn, affect the cellular morphology. It is instructive, however, to consider the effect of these parameters on the observed results for PU32, PU64, and PU96.

The detailed chemical makeup of the materials is proprietary information and is not known to these authors. Each is a polyether-based material but the specific isocyanate is not known. PU32 and PU64 were foamed as continuous buns having unrestricted freedom to rise. PU96 was poured in a form which also allowed unrestricted rise. Additives such as fire retardants, elasticizers, surfactants, and coloring agents are unknown as are formulation temperatures. Each of these items can affect the chemistry and/or molecular linkages and therefore the expansion characteristics. Each variable will affect the cell structure, however, so that the net effect of resin chemistry is reflected in the cell morphology and strength properties. As will be shown below, the expansion characteristics of the resins can be calculated. In spite of all foams being polyether based and expanded with fluorocarbon, thermal strains in the three lattices differ significantly.

The difference between the changing internal pressure and the external pressure define a temperature dependent stress on the foam. Internal pressures were computed using the procedure discussed under thermal conductivity and are tabulated in table 22. The experimental external pressures were $89.3 \mathrm{kPa}$ for PU32 and PU96, and $84.0 \mathrm{kPa}$ for PU64. Compressive Young's modulus, $E_{C}$, (Arvidson and Sparks, 1981; Arvidson, Sparks, and Guobang, 1983; and Arvidson, Bell, Sparks, and Guobang, 1983) and this pressure stress can be used to compute a strain. These computed strains are parallel to the direction of the experimental determinations and are tabulated in table 22. The uncertainty of the calculated 


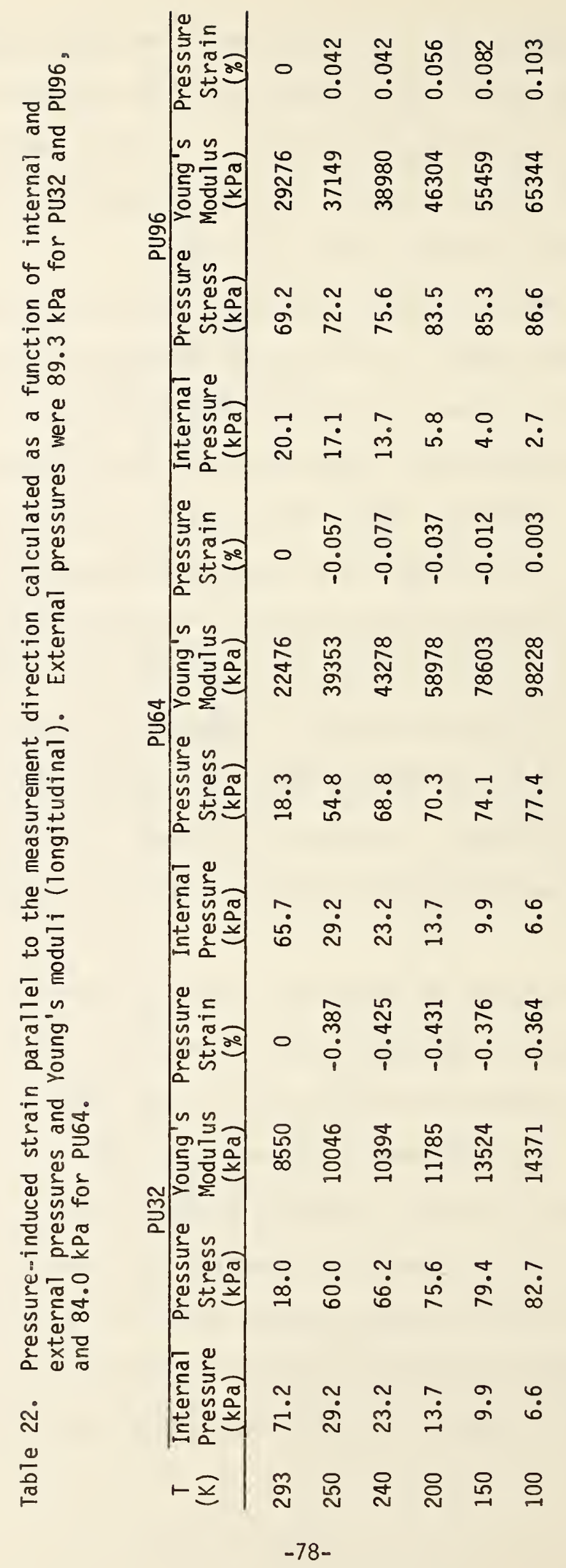


pressure-induced strains cannot be determined from available data. Straight-line behavior of $E_{C}$ (figs. 19, 26, and 34) was assumed in the temperature range from 100 to $293 \mathrm{~K}$. Deviations from this behavior could be significant, especially at temperatures far from the experimental data.

The difference between the experimentally observed contractions and the pressure-induced strain is the thermal contraction of the resin. These computed values are tabulated in table 23. If the pressure stress given in table 22 is applied to the foam in the transverse orientation, i.e., the transverse Young's modulus is used, the pressure-induced strain in this orientation can be computed. A value for the total transverse apparent thermal contraction can then be calculated by sumning the resin component and transverse pressure induced strain. These values are al so given in table 23. Figure 43 shows the comparative values of longitudinal (experimental) and transverse (calculated) thermal expansion. The effect of using a straight line approximation to Young's modulus at higher temperatures is to overestimate the pressure-induced strain and thereby cause the predicted values of resin contraction to be smaller than they actually are. The slightly positive values for resin contraction of PU32 at 250 and $240 \mathrm{~K}$ are thought to be caused by this approximation.

Thermal expansion of the resin as a function of density with temperature as a parameter is shown in figure 44. Resin expansion as a function of temperature can be determined from this family of curves for densities between 32 and $96 \mathrm{~kg} / \mathrm{m}^{3}$. The second component making up the observed thermal expansion is that caused by pressure-induced strain. This strain can be estimated from a knowledge of internal gas pressure, external gas pressure, and $E_{C}$. The internal gas pressure can be computed, as discussed in the thermal conductivity section, when the partial pressures are known. The compressive Young's modulus is discussed below. 


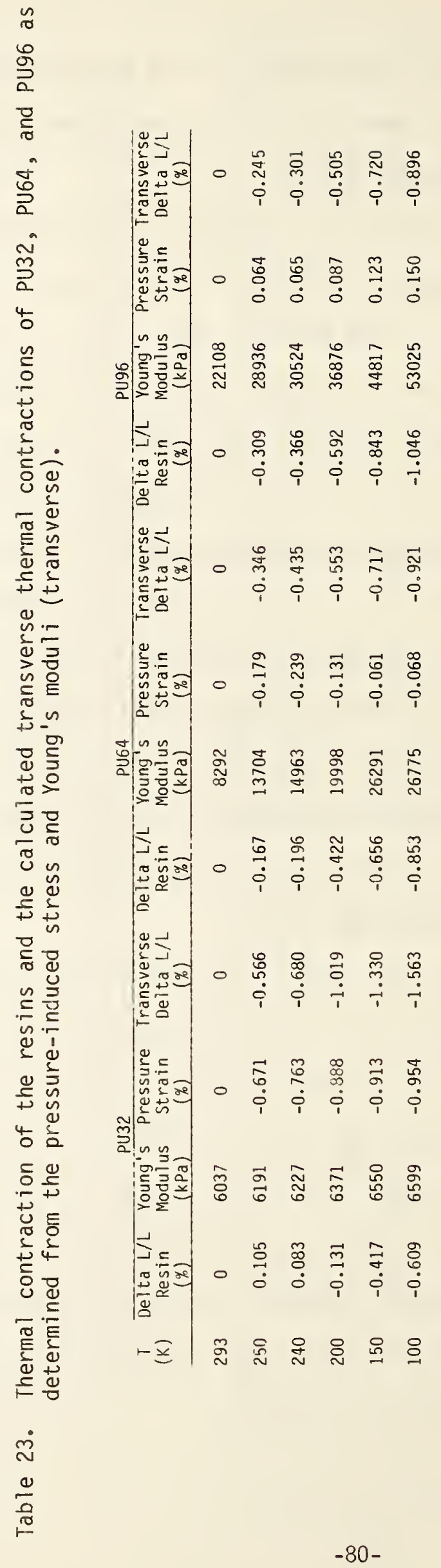




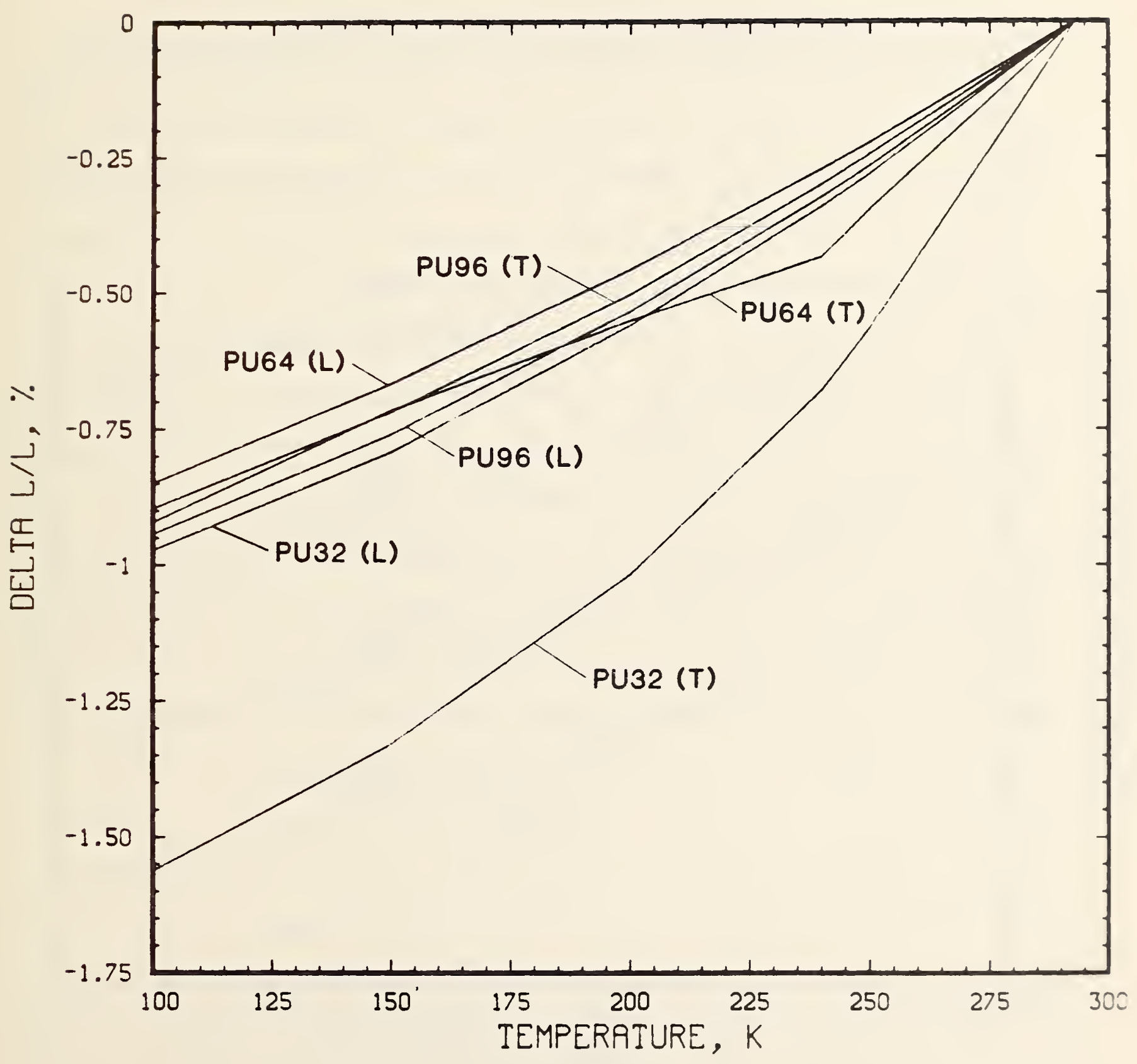

Figure 43. Longitudinal (experimental) and transverse (calculated) thermal contraction of PU32, PU64, and PU96. 


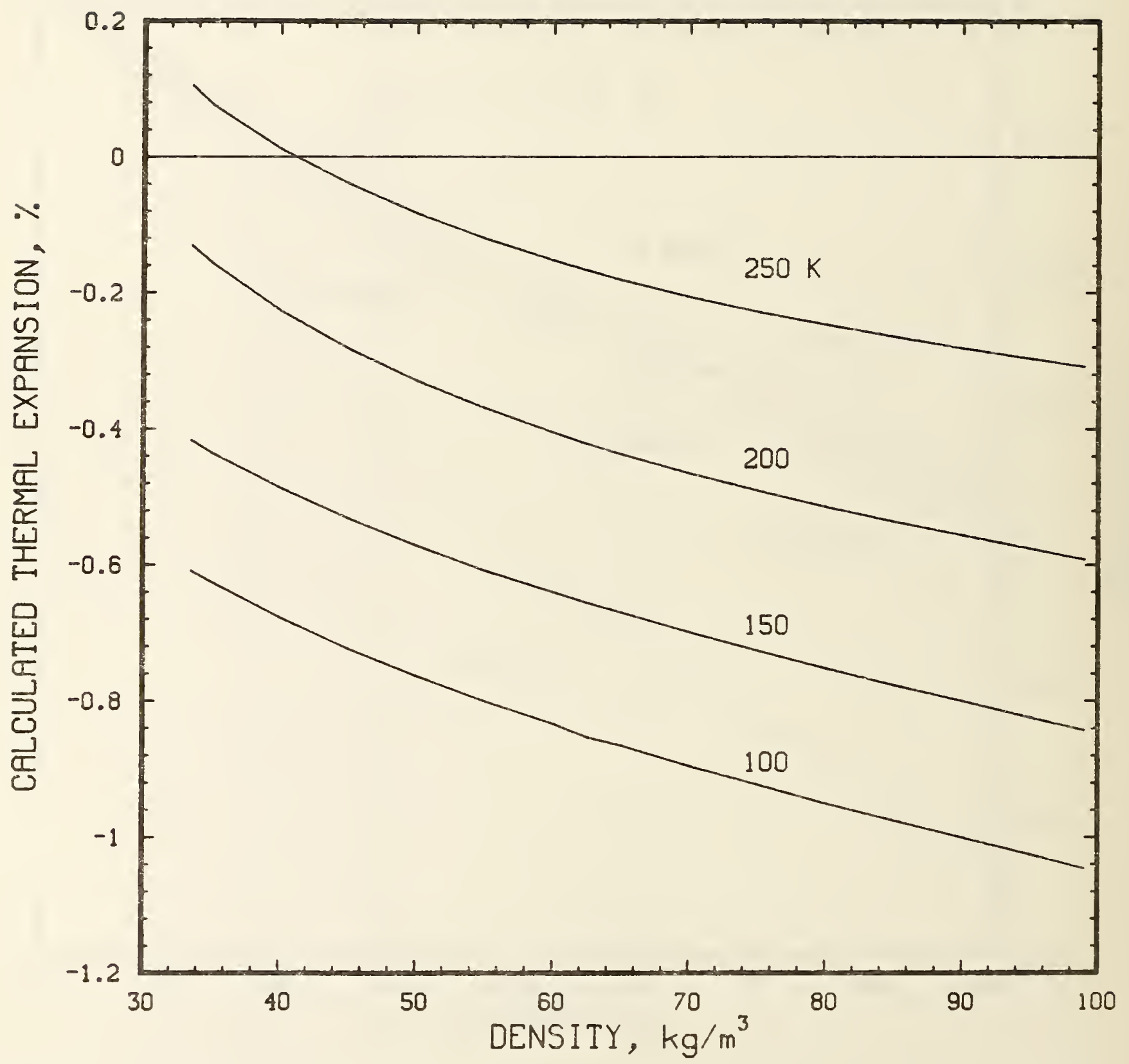

Figure 44. Calculated thermal contraction of polyurethane as a function of density with temperature as the paraneter. 
Mechanical properties - The strength properties near room temperature are traditionally represented by equations of the form

$$
\text { strength property }=A_{\rho}^{B}
$$

which is equivalent to

$$
\log \left(\text { strength property) }=A^{\prime}+B \log \right. \text { (density) }
$$

(Hilyard and Young, 1982; DuPont, 1979). DeGisi and Neet (1976) found that B $=1.75$ for both compressive strength and modulus, and that $A^{\prime}\left(A^{\prime}=\log A\right)$ was a linear function of temperature. Their formulation was limited to $T \geq 298 \mathrm{~K}$ for. strength and $T \geq 219 \mathrm{~K}$ for modulus for materials in the density range 153 to $392 \mathrm{~kg} / \mathrm{m}^{3}$. Cell size and orientation were not considered in developing the $\mathrm{r}$ empirical relationship. Menges and Knipschild (1982) present several theoretical developments for strength properties based on various assumptions concerning cell shape and orientations. None, however, have addressed developing relationships describing the strength behavior of foams as functions of temperature at cryogenic temperatures. The strength data and the characterization of cell size and shape reported here was intended to allow this possibility to be explored. A model, based on fundamentals and the current data and which would allow predictive capabilities for the mechanical properties, has not yet been established. The behavior of the compressive Young's modulus (figs. 19 and 26) and the tensile strength (figs. 24 and 31 ) in the temperature range 76 to $111 \mathrm{~K}$ was particularly difficult to incorporate into a model based on current understanding. An entirely empirical approach to establishing a predictive capability was therefore adopted. As is the case with all such relationships, the extent of its applicability to other polyurethane foams will be established through experience. Figures 45 through 48 , eq (14), the height-to-width ratio of the foam cells $(\mathrm{H} / \mathrm{W})$, and the foam density can be used to estimate average moduli and strength in 


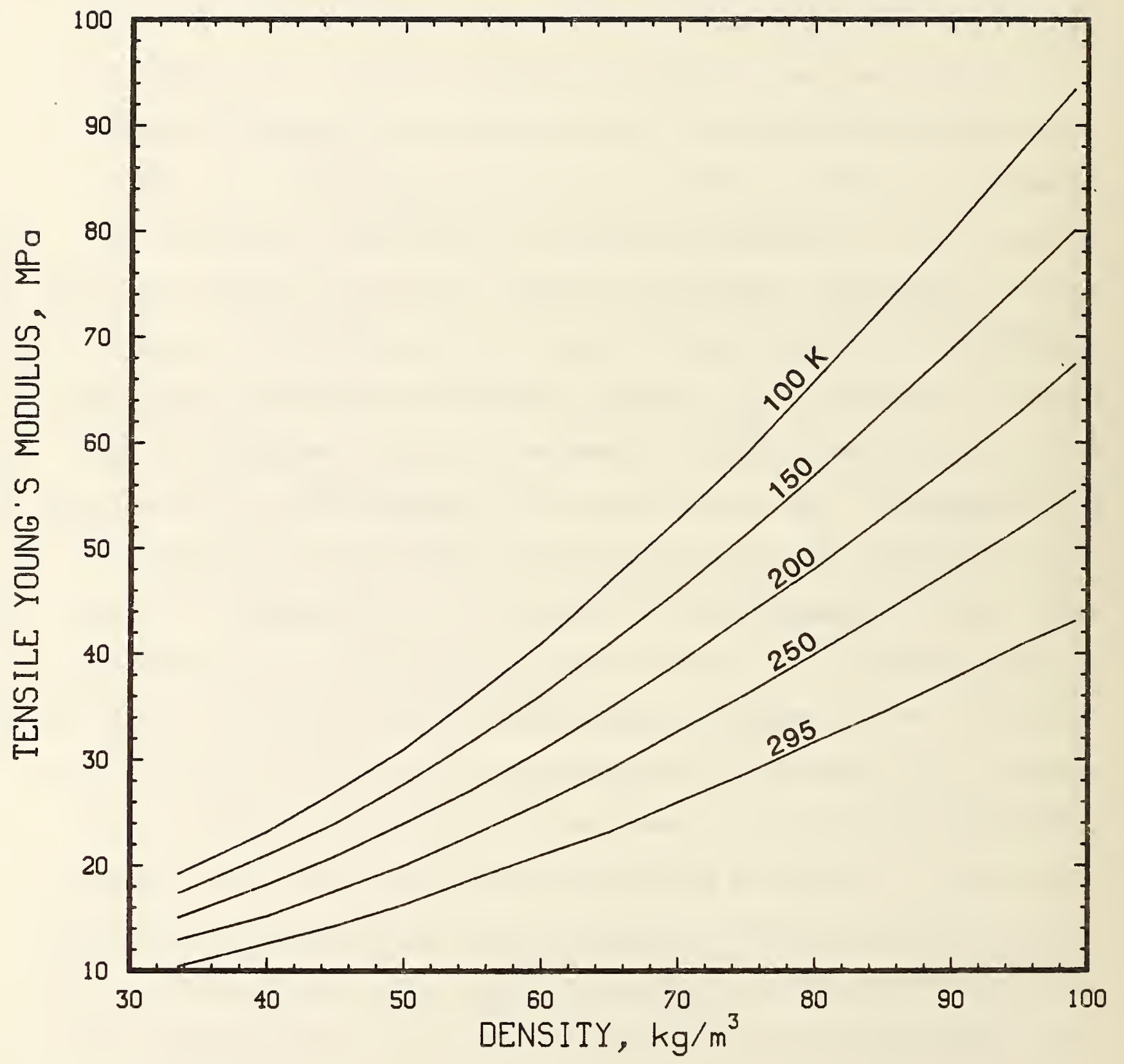

Figure 45. Young's modulus of polyurethane foam in tension as a function of density with temperature as the parameter. The modulus obtained here inust be nodified by a function of $(H / W)$ for a specific material. 


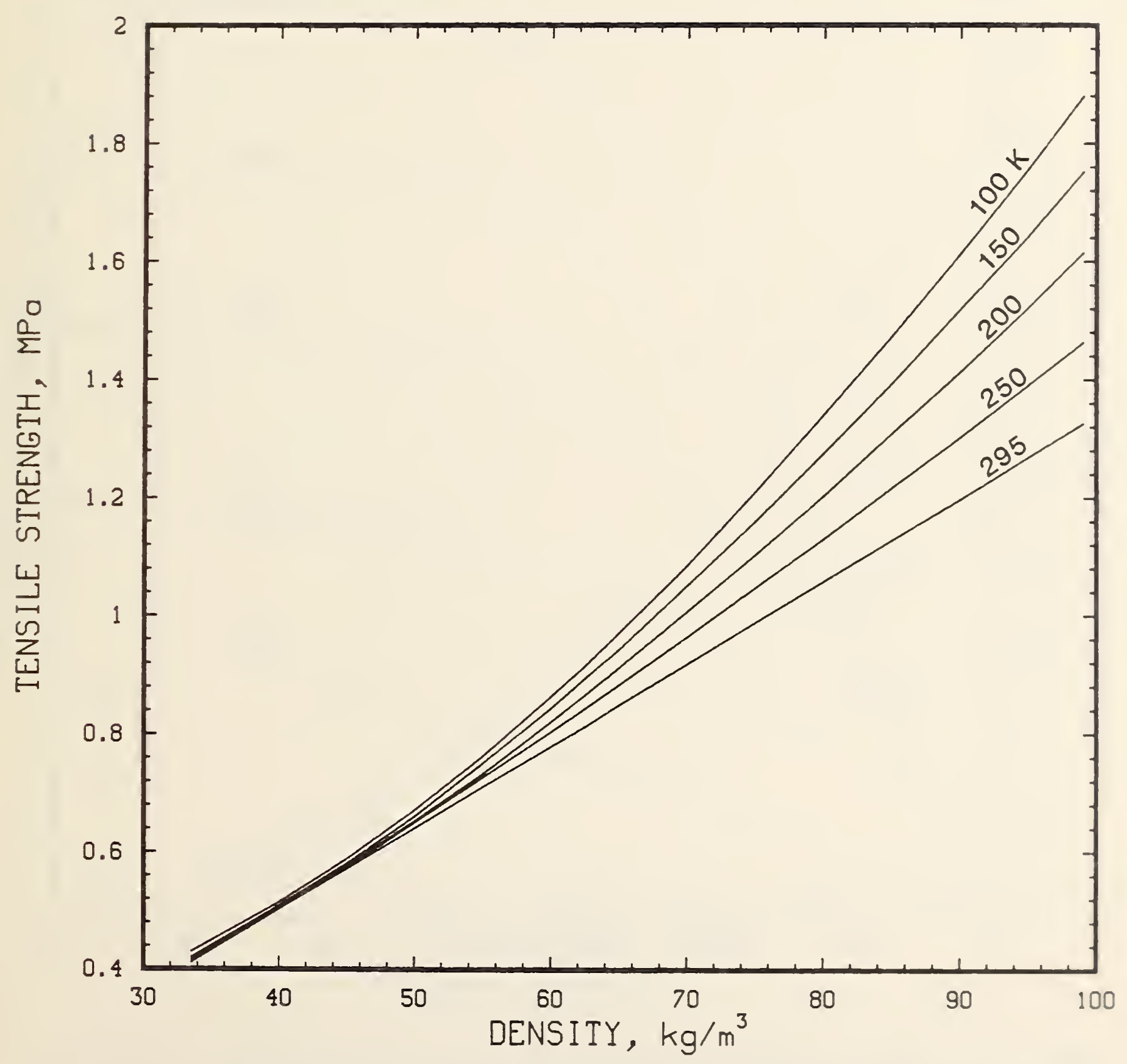

Figure 45. Strength of polyurethane foams in tension as a function of density with temperature as the parameter. Strength obtained here inust be modified by a function of $(H / W)$ for a specific material. 


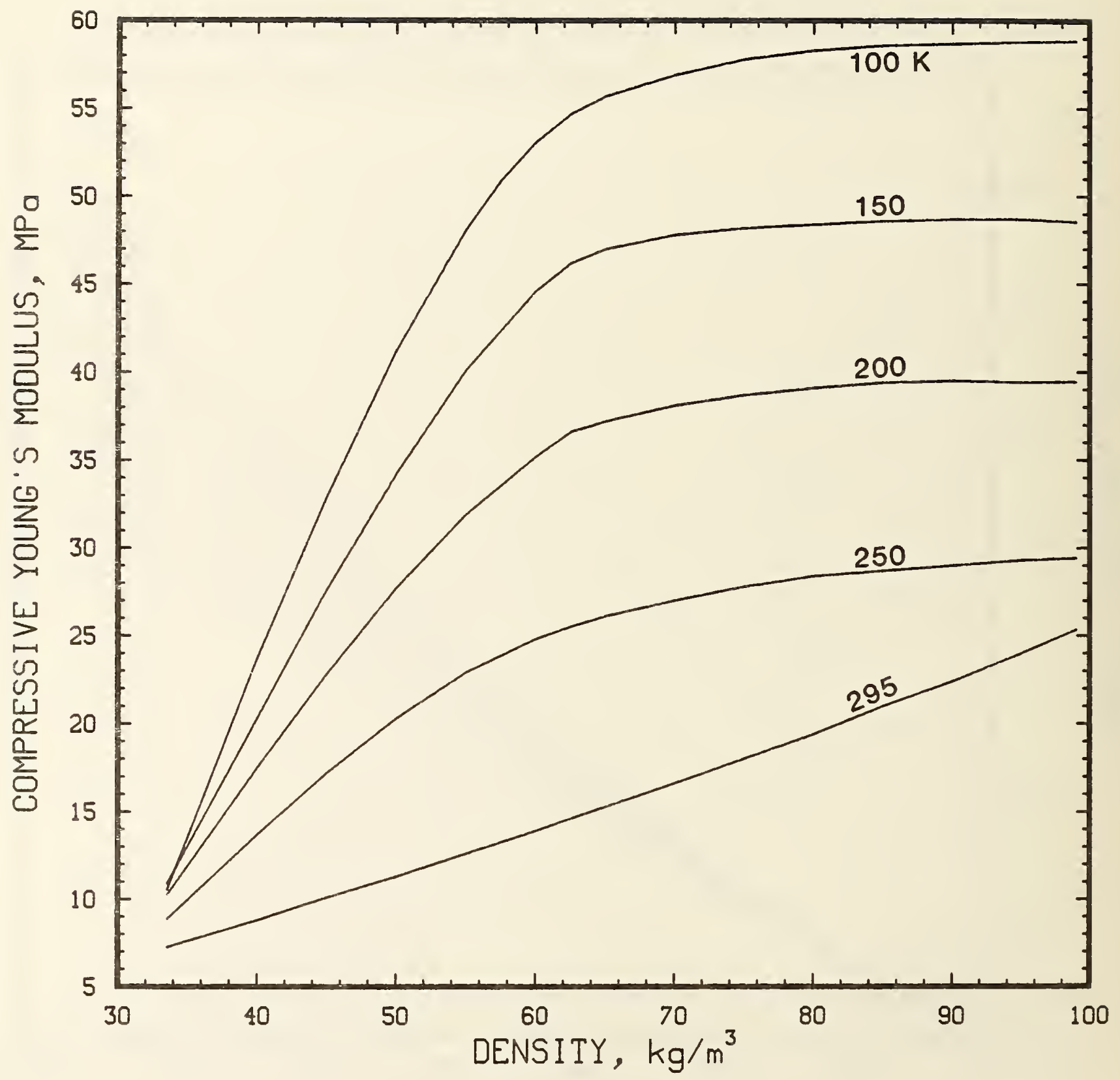

Figure 47. Young's modulus of polyurethane foam in compression as a function of density with temperature as the parameter. The modulus obtained here must be modified by a function of (it/W) for a specific material. 
tension and compression. The temperature range is 76 to $295 \mathrm{~K}$ and the density range is 32 to $96 \mathrm{~kg} / \mathrm{m}^{3}$. DeGisi and Neet (1976) found that crosslink density, urethane to urea bond ratio, and type of isocyanate had no significant effect at temperatures below about $350 \mathrm{~K}$.

Factors for the direction of stress relative to the elongated cell axis are

$$
\begin{aligned}
F(\text { longitudinal }) & =1 / 2\left\{[0.6+0.15(H / W)]^{-1}+(H / W)\right\} \\
F(\text { transverse }) & =1 / 2\left[0.85-0.1(H / W)+(H / W)^{-1}\right]
\end{aligned}
$$

The temperature dependent values at a particular density, from figures 45 ihrough 48 , must be nultiplied by this factor. This procedure produces values for the strength properties that are generally within $\pm 20 \%$ of the NBS experimental data. ilajor Achievements (IF)

The low temperature data base for polyurethane foams has been significantly improved with the addition of the data generated by this effort. These data are unique in that they include all basic thermophysical properties of interest to insulation users, and they are related to materials whose morphologies are also known. The materials used span the range of densities usually considered for thermal insulation applications.

Empirical relationships and procedures were developed for predicting the thermophysical properties of polyurethane foams at low temperatures. A minimum of infornation, which is relatively easy to acquire, is needed to use with these procedures.

Testing procedures for use on viscoelastic materials were refined. These procedures could be adopted for general use in lieu of standard procedures which are not intended for use at low temperatures. Revised stanklard procedures are, of course, the ultimate goal in this area. A basis and need has been established for standard materials as well as procedures. 


\section{Major Technical Problems (IF)}

Three areas presented technical problems which persisted to the end of the prograin and had significant impact on the results: meaningful characterization of materials, material variability, and anomalous behavior of the physical properties.

The materials studied were obtained from connercial producers because of the experience and expertise required to produce well designed foams. The chemical composition and foaming parameters were proprietary and in essence, only the polyether base could be determined. The characterization technique which best addressed our needs was statistical evaluation of photomicrographs. This procedure is time consuming, and an extreme effort is required to obtain sufficient data for statistical characterization.

Material variability was high for all materials; the concomitant uncertainties can only be assessed by large numbers of repeat measurements. Time and funding caused compromises in this area. The variabilities themselves are of interest since they reflect what a user must expect in batch lots of foam.

The physical property data are complicated at cryogenic temperatures. Modeling based on fundmentals was not possible due, in part, to unexplained temperature effects. Conclusions (IF)

Thermophysical properties of foams at low temperatures are functions of temperature, cell morphology, and gas content. Empirical procedures have been developed which allow predictions of thermal conductivity, thermal expansion, and tensile and compressive properties at low temperatures for a range of densities. Parameters which must be determined in order to make use of these procedures are indicated in table 24. The empirical procedures are based on the results for three particular polyuretinane foams. Application to other polyurethane foams must be evaluated. 
Table 24. Parameters needed to estinate the thermophysical properties of polyurethane foams as a function of temperature.

\begin{tabular}{|c|c|c|c|c|}
\hline \multirow[b]{2}{*}{ Property } & \multicolumn{4}{|c|}{ Material Parameters } \\
\hline & $\begin{array}{c}\text { Foam } \\
\text { Density }\end{array}$ & $\begin{array}{c}\text { Gas } \\
\text { Content }\end{array}$ & $\begin{array}{c}\text { Gas } \\
\text { Pressure }\end{array}$ & $\begin{array}{l}\text { Cel jular } \\
H / W\end{array}$ \\
\hline Thermal Conductivity & $x$ & $x$ & $x$ & $x$ \\
\hline Delta L/L & $x$ & $x$ & $x$ & $x$ \\
\hline Tensile Strength & $x$ & & & $x$ \\
\hline Tensile Modulus & $x$ & & & $x$ \\
\hline Compressive Strength & $x$ & & & $x$ \\
\hline Compressive Moduius & $x$ & & & $x$ \\
\hline
\end{tabular}




\section{References (IF)}

Arvidson, J. M., Bell, R. S., Sparks, L. L., and Gaunbang, C. (198.3). Tensile, Compressive, and Shear Properties of a $95 \mathrm{~kg} / \mathrm{in}^{3}$ polyurethane Fodil at: Low Temperatures, NBSIR 83-1595, National Bureau of Standards, Boulder, CO. Arvidson, J. M. and Sparks, L. L. (1981). Low Temperature Mechanical Properties of a Polyurethane Foam, NBSIR 81-1654, National Bureau of Standards, Boulder, CO.

Arvidson, J. M., Sparks, L. L., and Guobang, C. (1983). Tensile, Compressive, and Shear Properties of a $64 \mathrm{~kg} / \mathrm{m}^{3}$ polyurethane Foam at Low Temperatures, NBSIR 33-1684, National Bureau of Standards, Boulder, CO.

ASTM Annual Book of Standards, American Society for Testing and Materials, Philadelphia, $P A$.

Standard C177. Steady-State Thermal Transmission Properties by Means of the Guarded Hot Plate, Part 18.

Barkley, R. M. (1983). Private communication. Dr. Barkley, Department of Chemistry, University of Colorado, Boulder, co. DeGisi, S. L. and Neet, T. E, (1976). Predicting the Conpressive Properties of Rigid Urethane Foam, J. Appl. Polym. Sci. 20, pp. 2011-2028. Du Pont (1979). Thermodynanic Properties of Freon 11 Refrigerant, Bulletin A-84529, E. I. Du Pont de Ne:nours Co., Wilinington, DE. Exner, H. E. (1969). Discussion of the Relation Between Grain Section and Grain Size, J. Inst. Metals 97, 191-192.

Gorring, R. L. and Churchill, S. W. (1961). Thermal Conductivity of Heterogeneous Materials, Chem. Eng. Prog. 57, 53-59. Harding, R. H. (1960). Determination of Average Cell Volume in Foamed Products, Mod. Plast. $\underline{37}, 156-213$. 
Harding, R. H. (1964). Heat Transfer Through Low-Density Cellular Materials, I and EC Process Design and Development $\underline{3}, 117-125$.

Hensler, J. H. (1968). The Relation Between Grain Section and Grain Size, J. Inst. Met. $\underline{96}, 190-192$.

Hilyard, N. C. and Young, J. (1982). Introduction, in Mechanics of Cellular Plastics, N. C. Hilyard, ed., MacMillan Pun. Co., New York, 21. Kirby, R. K. and Hahn, T. A. (1971). Fused-Silica Thermal Expansion, Standard Reference Material 739, Office of Standard Reference Materials, National Bureau of Standards, Washington, D.C.

Kirby, R. K. and Hahn, T. A. (1975). Copper Thermal Expansion, Standard Reference Material 736, Office of Standard Reference Materials, National Bureau of Standards, Washington, D.C.

Menges, G. and Knipschild, F. (1982). Stiffness and Strength-Rigid Plastic Foams, in Mechanics of Cellular Plastics, N. C. Hilyard, ed., MacMillan Pub. Co., New York, 27-72.

NASA (1975). High-Temperature Capacitive Strain Measurement System, NASA Tech. Brief B75-10069.

Products Research Comnittee (1980). Materials Bank Conpendium of Fire Property Data, J. W. Lyons, Chairman, National Bureau of Standards, Washington, D.C. Reed, R. P., Arvidson, J. M., and Durcholz, R. L. (1973). Tensile Properties of Polyurethane and Polystyrene Foams from 76 to $300 \mathrm{~K}$, in Advances in Cryogenic Engineering 18, K. D. Timmerhaus, ed., Plenum Press, New York, NY, 184-193.

Rice, D. M. and Nunez, L. J. (196?). Average Cell Volume of Rigid Polyurethane Foams by Means of an Air Comparison Pycnometer, SPE J. 18, 321-323. 
Roberts, J. M., Herring, R. B., and Hartman, D. E. (1958). The Use of Capacitance Gauge Sensors to Make Precision Mechanical Property Measurenents, in Materials Technology, American Society for Mechanical Engineers, New York, $87-96$.

Schael, G. W. (1967). Characterization of the Structure of Cellular Plastics, J. Appl. Poly. Sci. 11, 2131-2142.

Skochdopole, R. E. (1961). The Thermal Conductivity of Foamed Plastics, Chem.

Eng. Prog. 57, 55-59.

Smith, C. S. and Guttinan, L. (1953). Measurement of Internal Boundaries in

Three-Dimensional Structures by Random Scattering, J. Met. 197, 81-87. Smith, D. R., Hust, J. G., and Van Poolen, L. J. (1981). A Guarded-Hot-Plate Apparatus for Measuring Effective Thermal Conductivity of Insulations Between $30 \mathrm{~K}$ and $360 \mathrm{~K}$, National Bureau of Standrads (U.S.), NBSIR 81-1657. Somers, E. V. and Cyphers, J. A. (1951). Analysis of Errors in Measuring Thermal Conductivity of Insulating Materials, Rev. Sci. Instrum. 22, 583-586. Sparks, L. L. (1979). Cryogenic Foam Insulations: Polyurethane and Polystyrene, in Nonmetallic Materials and Composites at Low Temperatures, Plenum Publ ishing Corporation, New York, NY. Sparks, L. L. (1980). Low-Temperature Properties of Expanded Polyurethane dill Polystyrene, in ASTM STP 718, American Society for Testing and Materials, Philadelphia, PA.

Sparks, L. L. (1981). Thermal Conductivity of a Polyurethane Foam from $95 \mathrm{~K}$ to $340 \mathrm{~K}$, NBSIR 82-1664, National Bureau of Standards, Boulder, C0. Thompson, A. W. (1972). Calculation of True Volume Grain Diameter, Metallography $\underline{5}, 366-369$. 
Touloukian, Y. S., Liley, P. E., and Saxena, S. C. (1970). In Thermal Conductivity: Nonmetallic Liquids and Gases, Thermophysical Properties of Matter, Vol. 3, IF I/Plenum, New York, NY.

Tsederberg, N. V. (1.955). Thermal Conductivity of Gases and Liquids, MIT Press, Cambridge, MA, 144.

Tye, R. P. and Spinney, S. C. (1976). Thermal Conductivity of Concrete: Measurement Problems and Effect of Moisture, Bull. Int. Froid, Annexe 1976-2, $119-127$. 


\section{INSULATING CONCRETES}

Overall Project Objective (IC)

There are four immediate objectives for the insulating concrete effort:

(1) To collect information on commercially available insulating concretes.

(2) To evaluate existing data to determine applicability of test methods, quality of data, and fitness-for-service of insulating concretes.

(3) To perform thermal and mechanical property screening tests on selected materials.

(4) To select one or more of the available materials for further testing. The ultimate objective of the insulating concrete project is to supply the LNG industry with the data base needed to incorporate one or more of the insulating concretes into plant design.

\section{Project Description (IC)}

A literature search designed to reveal information from past research on insulating concretes was done. This effort was initiated by a computerized search in the following data bases: COMPENDEX, INSPEC, NTIS, and SSIE (further information in reference section under Data bases). The references cited in the computer identified papers were al so selectively collected.

Screening tests performed at NBS to supplement the literature survey consisted of measuring the thermal conductivity of five candidate types and the modulus of rupture and the compressive strength of four candidate types of concretes. The materials were supplied by three private companies and Brookhaven National Laboratory (BNL).

In addition to the information collected from the literature and the screening tests, discussions with users and producers of insulating concretes were also of value in evaluating these materials. The interest generated by this survey for polymer based materials resulted largely from these discussions. 
Project Rationale and Projected Benefits (IC)

Increased use of LNG and other liquid fuels along with more stringent safety regulations, i.e., Congressional Record 193.2059 (Federal Register, 1980) entitled Flammable Vapor-Gas Dispersion Protection, have created a need for an inexpensive, abundant material to be used in the construction of storage tank dikes and basins. One or more of the insulating concretes could be developed to fill the gap existing between the properties of good insulators, such as expanded plastics, and natural naterials, such as sand/soil/rock. The general attributes needed for the dike/basin application include a reasonable degree of inpermeability to water and liquid fuels, nechanical strength to support service venicles, long unattended iifetime, ease of installation, material integrity when subjected to thermal shock, a relatively low thermal conductivity, and a relatively low cost. Once developed, use of a material with these attributes will almost certainly not be 1 imited to dike construction.

Insulating concrete is common in the construction industry at the present time and several commercially produced products are available. The primary applications are roof insulations, firewalls, and air conduits. The engineering data developed for these purposes is not sufficient for design of cryogenic fuel storage installations.

The benefits of developiny and using such a llaterial are enormous both from the standpoint of safety and efficient land utilization. Insulated dike/basin areas would allow new tanks to be sited in populated areas, i.e., near the users, and in the event of a catastrophic tank failure and fire, would minimize botin ioss of life and property damage. 


\section{TECHNICAL DISCUSSION (IC)}

Work Plan (IC)

Three sources of information were available for assessing insulating concretes: open literature, industry files and experience, and new experimental data. The literature search and discussions with industry were to be concurrent and last from beginning to end of the effort. The experimental portion was designed to fill in gaps in information from the other sources. Three screening tests, thermal conductivity, modulus of rupture, and compressive strength were selected. The mechanical tests were to be done at 76 and $300 \mathrm{~K}$. Based on all information available at the end of the survey period, a recommendation was to be made regarding materials and further reseach.

Work Performed and Results (IC)

The literature search resulted in 301 hard copies and microfiche. Of these, approximately 30 contained data which could be used directly to evaluate and select materials for use in dikes and impounding areas. The number of references containing data for low temperatures is even more restricted. Annotated bibliographies have been prepared for nine of the technical papers: expanded shaleportland cement (Monfore and Lentz, 1962; Lentz and Monfore, 1965), vermiculite-, perlite-, or polystyrene-portland cement (Adams, 1969; Reid and Wang, 1978; Reid, 1980), cellular-portland cement (Richard, Dobogai, Gerbardt, and Young, 1975; Richard, 1977), polymer matrix (Lang, Moorhouse, and Paul, 1980; McClune and Moorhouse, 1981). These bibliographies follow the References (IC) section. The remaining sources are given in the References (IC) section. The information contained in these papers is of a general interest nature. It was not possible to group these diverse papers into meaningful sets so titles were included in the references and can be used as guidelines to the paper's contents. Data from the literature search are shown in figures 49 through 52. 


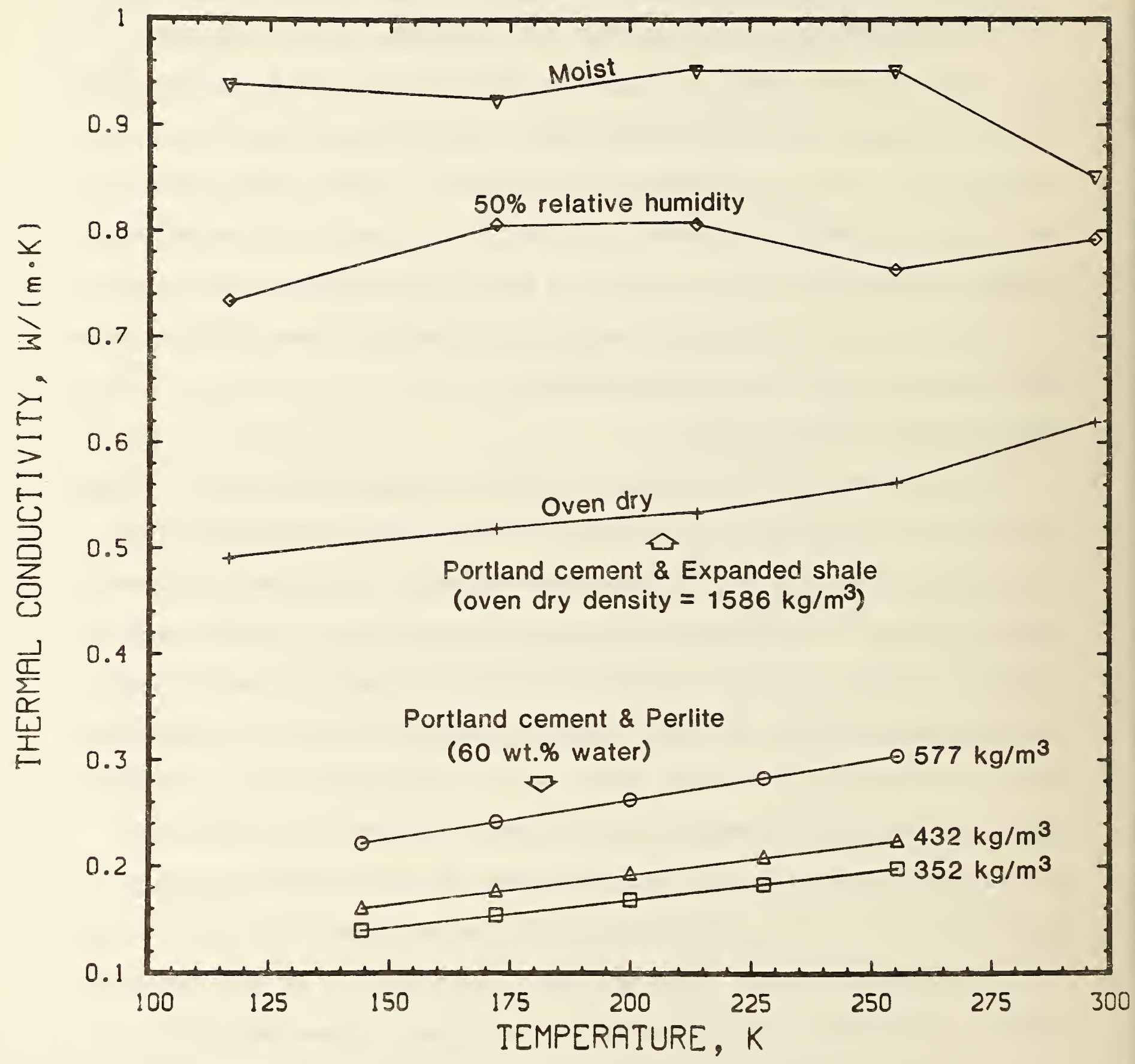

Figure 49. Thermal conductivity as a function of temperature with moisture content (Lentz and Monfore, 1965) and density (Adams, 1969) as parameters. 


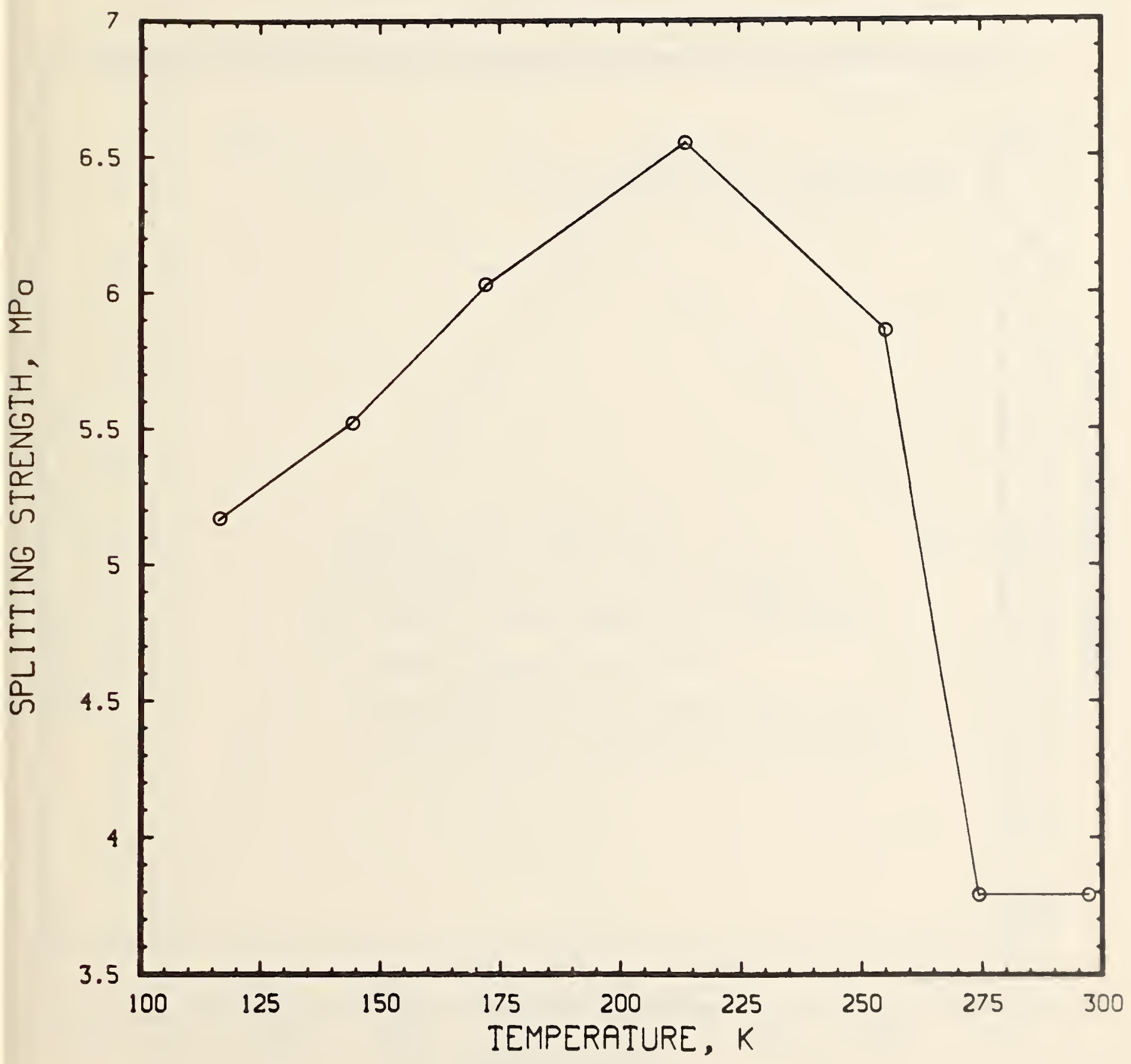

Figure 50. Splitting strength as a function of temperature for an expanded shale concrete with density of $1554 \mathrm{~kg} / \mathrm{m}^{3}$ (Monfore and Lentz, 1962) 


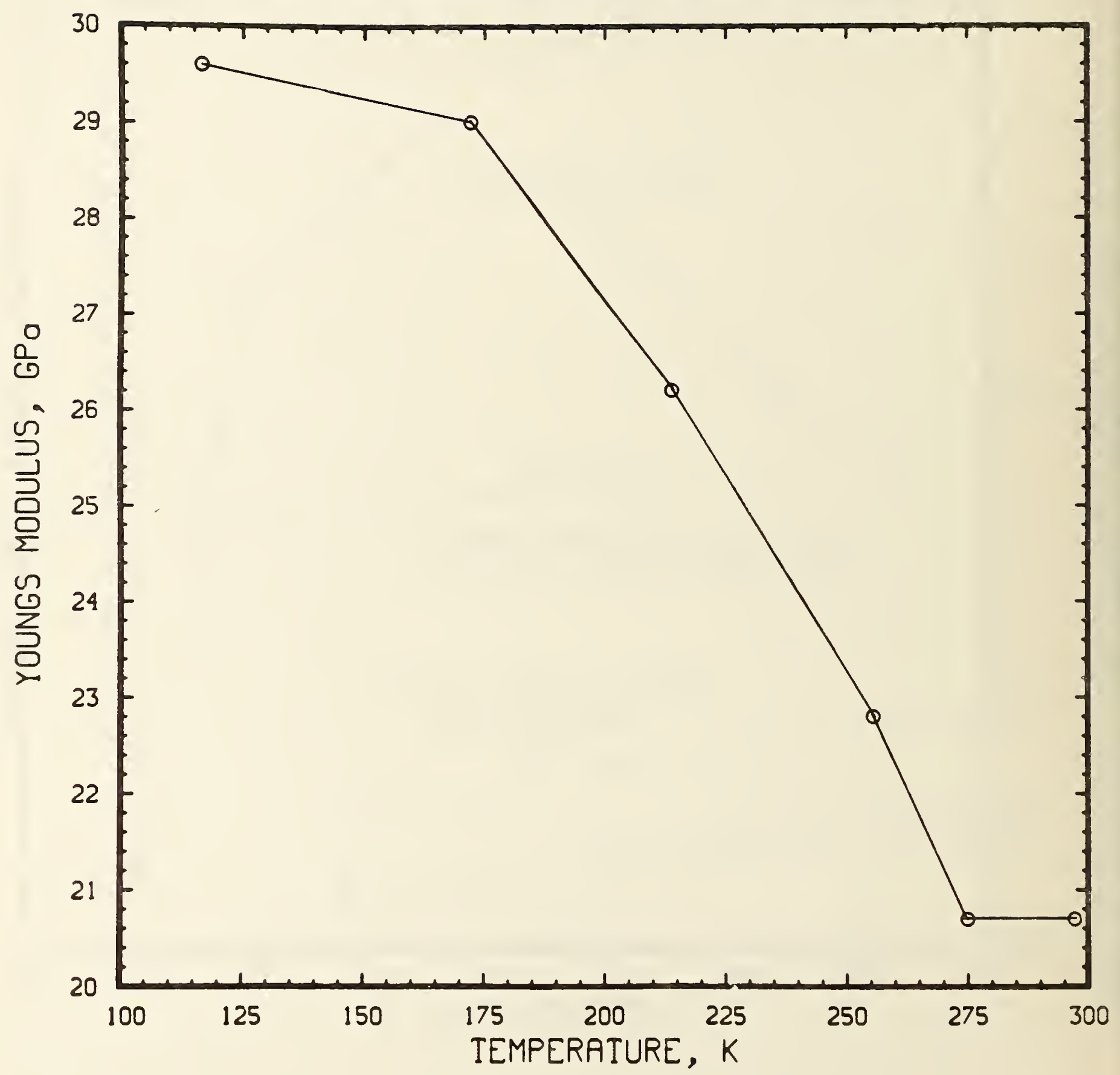

Figure 51. Compressive Young's modulus as a function of temperature for an expanded shale concrete of density $1554 \mathrm{~kg} / \mathrm{m}^{3}$ (Monfore and Lentz, 1962). 
Table 25 lisis the companies and people contacied regarding lightweight concrete. Some entries represent a single phone contact, while others involved personal visits and extensive correspondence. Materials used in the experimental phase were acquired from organizations listed in this table. Discussions with members of the GRI Advisory Group were useful in establishing the needs of industry as well as the general state of knowledge of insulating concretes.

Screening test.s performed in support of the literature survey resulted in data for thermal conductivity, compressive strength, and modulus of rupture. These data are plotted in figures 53 through 55 .

The thermal conductivity data, figure 53, were obtained in an insulating vacuum environment. The values for poritidnd/polystyrene are lower than those usually reported because of porosity and the concomitant lack of yds conduction. The values for the less porous polyester-based naterials are not expected to be strongly affected by the vacuum environnent. Adjusting the portland/polysiyrene values to account for the lack of yas conduction would increase the conductivity at $285 \mathrm{~K}$ to approximately $0.07 \mathrm{~W} /(\mathrm{m} \cdot \mathrm{K})$. The empirical rel ationsinip given later in eq (13) yields a conductivity of $0.08 \mathrm{~W} /(\mathrm{m} \cdot \mathrm{K})$ for this mix. Discussion of Results (IC)

Although the datd inde for insulatinj concretes is very limited, several tentative conclusions can be drawn from the available information. Compressive strength and chermal conductivity can be used to evaluate the relative nerits of the candidate materials.

In order to allow tank maintenance, light traffic inusi is dilowed in the tank basin. A minimum compressive strength of $5 \mathrm{MPa}$ (725 psi) is estimated. The screening tests at NBS (fig. 54) indicate that the particular specinen of portland-polystyrene $\left(342-\mathrm{kg} / \mathrm{m}^{3}\right.$ density) is not strong enough for this 
Tále 25. Industrial sources of information and/or materidls used in the iVBS/GRI survey of insulating concretes. This list is not comprehensive in regard to companies involved with lighiweight concretes and no endorsement. is implied.

Company

Telephone

Contact Person

BASF

Parsippany, $\mathrm{NJ}$

British Columbia Hydroelectric (604) 298-1311 Vancouver, BC

Britis! Gas Sol ihul1, U.K.

Brookhaven National iat) Upton, NY

Chicago 3ridge $\alpha$ Iron Plainfield, IL

Concordia In iversity Montreal, Quebec

Concrete Technology Tacoma, WA

Global Marine Newport Beach, CA

Institute of Gas Technolisijy Chicago, IL

Koppers

$$
\text { Pittsburgh, PA }
$$

Lonestar Los Angeles, CA

Massachusetts Institute of

Technology Cambridge, MA

National Bureau of Standards Gdithersburg, i仿

Norton Worcester, MA

Perlite Institule New York, NY

Portland Ceinent Association Skokie, IL

Preload Technology Garden City, NY

Respect. A Ainerica Elk Grove, IL

San Diego Gas and Electric San Diego, CA

Shell International London, Engl and

Sunderland PolytecricSunderland, Engl and

T. $Y$. Lin Internatiund San Francisco, CA

Testing Engineers, San Diego San Diego, CA

United Staies Navy Port Hueneme, CA

W. R. Grace

Denver, CO
(201) 263-3400

$44-21-705-7581$

(516)282-?12:3

(815) 436-2912

(514) 879-5995

(2015) 383-3545

(714) 752-5050)

(312) 567-37:26

(412) 227-2279

(213) 703-1267

(617) 835-1000

(202) 921-2810

(617) 853-1000

(212) 265-2145

(312) $966-6200$

(516) 222-0550

(312) 860-5999

(619) 232-4252

44-1-93!-1?34

44-7-837-9315

(415) 982-105!)

(619) 225-9641

(805) 982-5923

(303) 72?-5707
Bill Fairweather

Robert Booth and

Ken Griffiths

John Moorhouse

Mayer Steinberg, Lawrence Kukacka, and Toshi sugama Anthony Bellafiore

Norman Low

Arthur Anderson

A'rranam Person

Phillip Anderson

George Stiffy

M. Gunasekaran

Robert Reid

Geoff Frohnsdorf

David Rostoker

Robert Milanese

Paul Klieger, David Whiting, and Albert Litvin Nicholas Legatos

Larry Farrel 1

Barry Brunelle

Collin McClune

A. L. Marshall

Harvey Haynes

Bill de Berry

Robert Rail

Gary Poindexter 


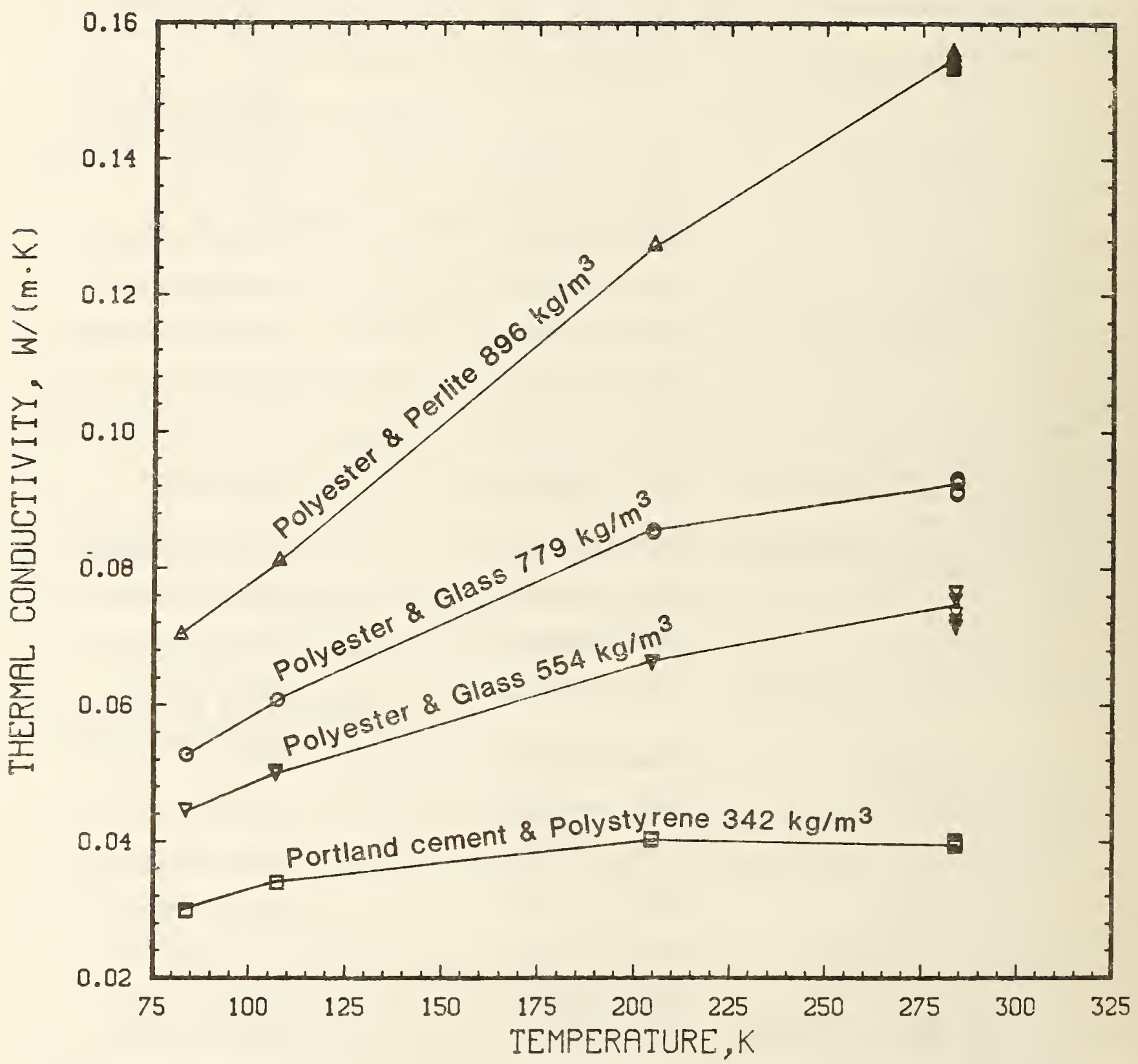

Figure 53. Thermal conductivity of several insulating concretes as a function of temperature. The testing environment was insulating vacuum. 


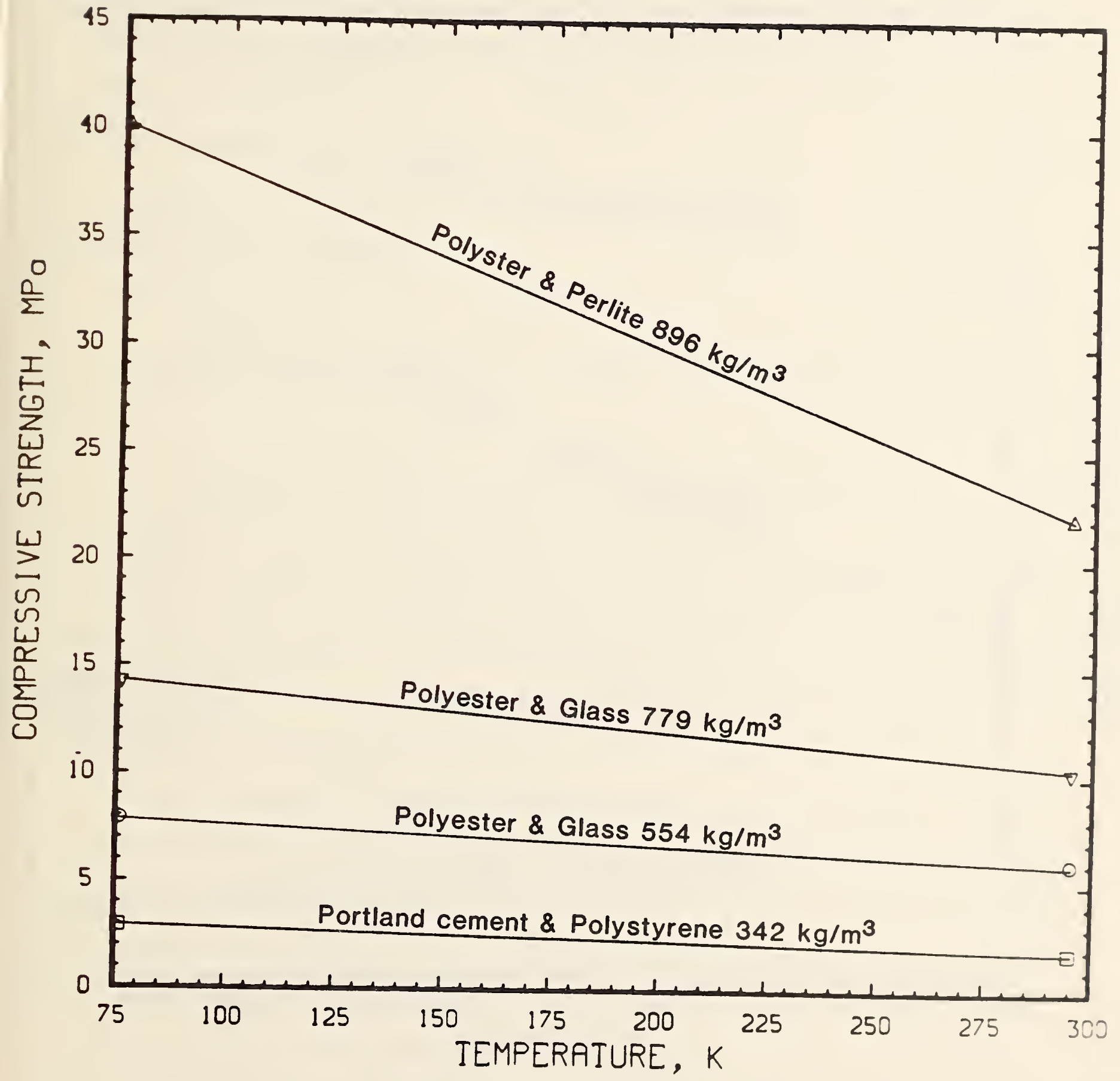

Figure 54. Average compressive strength of several insulating concretes as a function of temperature (determined at NBS). 


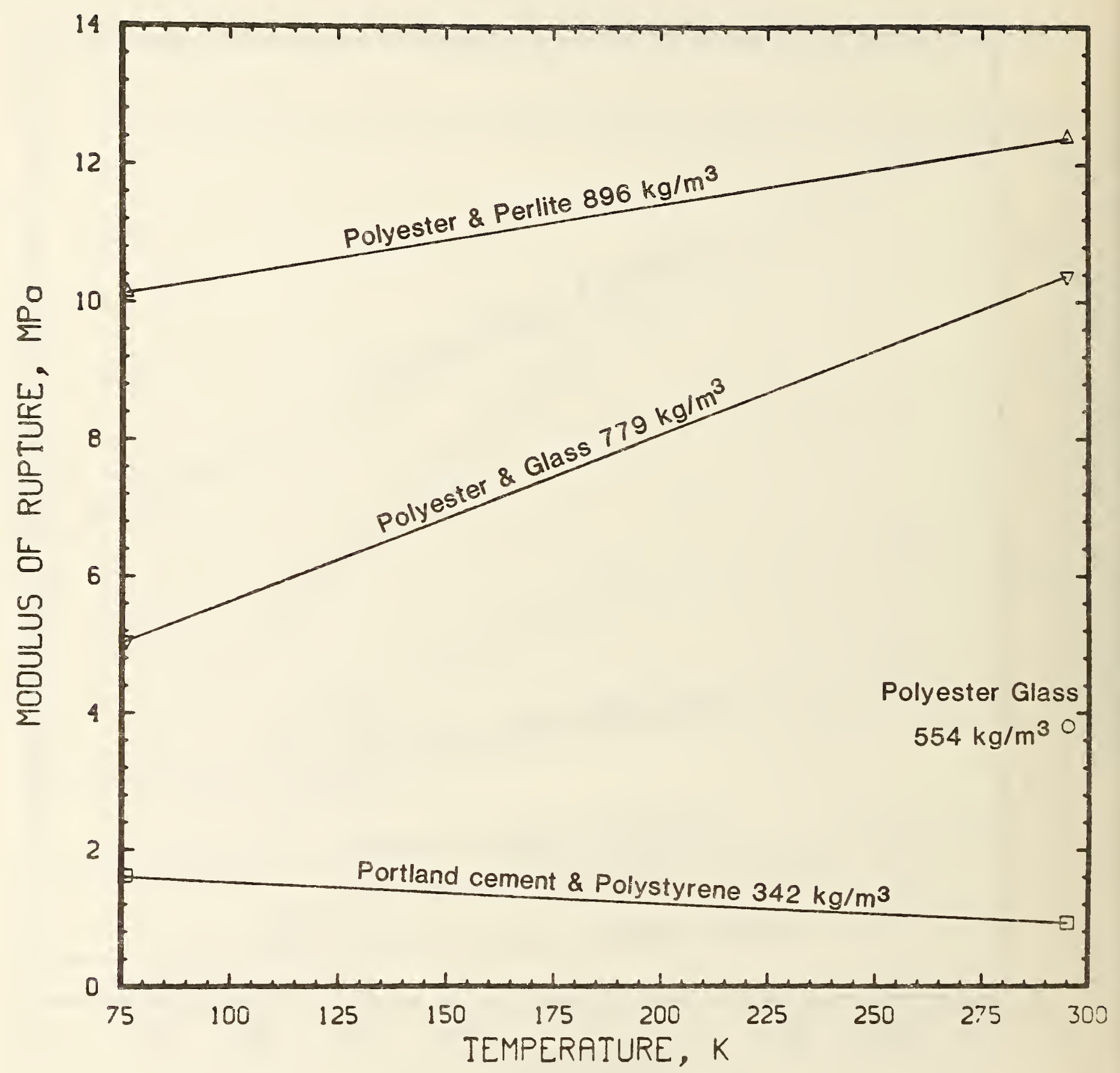

Figure 55. Average modulus of rupture of several insulating concretes as a function of temperature (deteriined at NBS). 
application and that one of the polyester-glass materials $\left(554-\mathrm{kg} / \mathrm{m}^{3}\right.$ density) is inarginal in this respect. For portland-cement-based naterials this criterion, used in eq (15), estajlishes a mininuin density of aiout $725 \mathrm{~kg} / \mathrm{m}^{3}$. As seen in figures 52 and 54, compressive strength increases or remains approximately constant as teinerature decrases. Anbient tenperature data can therefore be used as the worst case situation.

Compressive strength as a function of density $\left(\right.$ in $k_{i j} \cdot i^{-3}$ ) at ambient temperature can be estimated by

$$
\text { Compressive Strength }=4.132 \times 10^{-3} \times \rho+4.469 \times 10^{-5} \times \rho^{2}
$$

for portland-cement-based materials. A similar, but much more tenuous relationship

$$
\text { Compressive Strength }=3.174 \times 10^{-3} \times \rho+1.639 \times 10^{-5} \times \rho^{2}
$$

can be used for polymeric-based materials. The least-squares fits in eqs (15) and (16) were based on data given by MCClune and Moorhouse (1981) and the NBS data given in this report. It must be stressed that these relationsinips are not intended to be precise but rather to express trends for widely different Inaterials as functions of density.

Selection of material based on thermal properties is more complex. The economics of the site area and inaterial costs would necessarily cone into play in making inis decision. The relative thermal property merits of the materials and the estimate of the effect of water absorption can, however, be estimated.

The solution to the one-dimensional heat flow equation for infinite slabs leads to the boil off rate for liquefied gas spills

$$
\dot{M}=(k \rho C)^{1 / 2}(\Delta T A) /\left(H_{v} \pi^{1 / 2} t^{1 / 2}\right)=(k \rho C)^{1 / 2} G
$$

where $G$ represents a collection of terms not related to the 5 lab material, 
$\dot{M}$ is the LNG boil off rate, $k$ is thernal conductivity, $\rho$ is density, $C$ is specific heat, $\Delta T$ is temperature difference between the LNG and substrate, $A$ is area, $H_{v}$ is heat of vaporization of Liva, and $t$ is time. The ambient temperature thermal conductivity for both poritand- and resin-ibasel concretes can be estimated by

$$
k=0.1453-3.1219 \times 10^{-4} \times \rho+3.8844 \times 10^{-7} \times \rho^{?}
$$

for dry materials. The boil-off rate can be expressed as a function of density and specific heat.

$$
\dot{y}=\left[\left(0.1453 \rho-3.1219 \times 10^{-4} \times \rho^{2}+3.8844 \times 10^{-7} \times \rho^{3}\right) C\right]^{1 / 2} G
$$

For purposes of comparison, specific hedi, of portland-based materials is $840 \mathrm{~J} / \mathrm{kg} \cdot \mathrm{K}$ (Yoshiwa and Iwata, 1977) while that for resin-based naterials is $1000 \mathrm{~J} / \mathrm{kg} \cdot \mathrm{K}$ (Sparks, 1983). For a given density, $\dot{\mathrm{M}}$ (polymer base) $=1.1 \dot{\mathrm{M}}$ (portland base). Due to uncertainties in the values of therinal conductivity and specific heat for nonspecific materidis, this $10 \%$ difference should be considered semi-quantitative.

Absorption of water is of inajor importance in selecting the dike/basin material. Lang, Moorinouse, and Paul (1980) and McClune and iloorhouse (19.31) have studied the rate of water uptake in various materials as well as alternative methods of reducing this phenomenon. Their work is summarized in the annotated bibliography section.

Concern about water uptake is due to the dependence of boil-off rate uil $\rho$, $k$, and C (eq 17); each of these parameters increase as water content increases. The relationship for thermal conductivity as a function of density (eq 18) applies to dry inaterials. Valore (1956) has shown enpirically that the thermal conductivity for a given specimen will increase by $5 \%$ for each $1 \%$ increase in 
density due to absorption of free water. Specific heat is also increased due to the relatively high heat capacity of water. The net effect of water absorption can be seen by comparison of LNG boil-off for a given material before and after water absorption. Properties of the material in the oven-dry condition are $\rho$ $=1586 \mathrm{~kg} / \mathrm{m}^{3}, \mathrm{k}=0.62 \mathrm{~W} / \mathrm{m} \cdot \mathrm{K}$, and $\mathrm{C}=840 \mathrm{~J} / \mathrm{kg} \cdot \mathrm{K}$. The resulting LNG boiloff is $\dot{M}=909 \mathrm{G}$. After 10 volume percent ( $6.3 \%$ by weight) water absorption, $k$ $=0.82 \mathrm{~W} / \mathrm{m} \cdot \mathrm{K}, \rho=1686 \mathrm{~kg} / \mathrm{m}^{3}$, and, by the rule of mixtures, $C=1051 \mathrm{~J} / \mathrm{kg} \cdot \mathrm{K}$ Boil-off for the damp material is $\dot{M}=1205$ G. $\dot{M}$ (damp) $/ \dot{M}($ dry $)=1.33$, or an increase in LNG boil-off of $33 \%$. An increase of this magnitude significantly alters the distance down wind from the tank at which a $5 \%$ methane concentration occurs (Arthur D. Little, 1974). McClune and Moorhouse (1981) find absorption in the range 10 to 30 volume percent for untreated portland-based materials so that the effect computed above is approaching a minimum that must be expected.

The ratio of compressive strength to thermal conductivity, Q, can be used as an indicator of the relative fitness of materials for use in dike/basin areas. It does not, however, take several very important factors into account, e.g., initial cost, maintenance, flamability, and water absorption. This ratio is given in table 26 for the lightweight concretes tested at NBS and for several materials reported in the literature. Ordinary concretes, which are stronger but have higher conductivity, have Q values on the order of 20. The resin-based materials listed in the table are suggested by this ratio while the portland/ polystyrene materials appear to be least usable. Portland/expanded shale is the most dense material considered. The $Q$ for this material approaches that of the resin-based mixes. 
Table 26. Density, thermal conductivity ( $k$ ), compressive strength (CS), and the ratio $Q$ $=\mathrm{CS} / \mathrm{k}$ for the lightweight concretes tested at NBS and for several materials reported in the literature. The data are for $295 \mathrm{~K}$.

\begin{tabular}{lccccc}
\hline \multicolumn{1}{c}{ Material } & Source & $\begin{array}{c}\text { Density } \\
\left(\mathrm{kg} \cdot \mathrm{m}^{-3}\right)\end{array}$ & $\begin{array}{c}\mathrm{k} \\
\left(\mathrm{W} \cdot \mathrm{m}^{-1} \cdot \mathrm{K}-1\right)\end{array}$ & $\begin{array}{c}\text { CS } \\
(\mathrm{MPa})\end{array}$ & $\begin{array}{c}\text { Q } \\
(\mathrm{MPa} \cdot \mathrm{m} \cdot \mathrm{K} \cdot \mathrm{W}-1)\end{array}$ \\
\hline polyester/perlite/BNL & NBS & 896 & 0.15 & 22 & 143 \\
polyester/glass/BNL & NBS & 779 & 0.09 & 10.5 & 114 \\
polyester/glass/Rostoker & NBS & 554 & 0.07 & 6 & 81 \\
portland/polystyrene & NBS & 342 & 0.07 & 2 & 28 \\
epoxy/resin/concrete & A & 1100 & 0.3 & 42 & 140 \\
polyester/fine clay & A & 1425 & 0.4 & 37 & 92 \\
portland/polystyrene & A & 445 & 0.1 & 1 & 10 \\
portland/expanded shale & B & 1554 & 0.8 & 41 & 51 \\
\hline
\end{tabular}

A: McClune and Moorhouse (1981).

B: Lentz and Monfore (1965); Monfore and Lentz (1962). 


\section{Major Achievements (IC)}

The results of the literature survey and the discussions within the userproducer communities emphasized the undeveloped state of the candidate materials for cryogenic applications. Interactions based on the information available has helped to redirect industrial efforts to develop usable material(s). Polymerbased materials are now being evaluated more thoroughly in this country.

\section{Major Technical Problems (IC)}

The over-riding problems encountered were the lack of low temperature data in the literature and user inexperience with the candidate materials. This placed an unexpected burden on the experimental screening effort. The term and funding of the survey were not sufficient to obtain and perform necessary tests on the variety of materials and the range of densities needed to establish quantitative selection criteria.

\section{Conclusions (IC)}

The thermophysical properties recommend resin-based materials for use in dike/basin applications. The choice of these materials over lightweight portland-cement-based materials is due to high strength-to-weight ratio and low thermal conductivity. Low absorption allows thermal conductivity to remain fixed after exposure to water. There are, however, unanswered questions which must be addressed before these materials can be used in the proposed applications. Resins are organic in nature and are therefore relatively flammable. The effectiveness of fire retarding additives in preventing resin combustion must be thoroughly evaluated before installation around a LNG tank. Resin-based materials are inherently more expensive, at least initially, than portland-based materials. This fact will lead to use of resin-based materials as caps on less 
costly substrates. The quality of bond between cap and substrate and the effect of environmental extremes on this bond must al so be evaluated.

Strength-to-weight ratios for portland-cement-based materials are lower than those for the resin-based materials. Relatively dense mixes are required to meet the strength requirements and the thermal conductivity is a function of density. Water absorption in these materials also causes thermal conductivity to increase. It has been shown that reasonably low equilibrium levels of free water can be maintained by particular mix treatments. In view of this and the possibility of further alleviation of absorption problems by drainage design, these materials should not be disregarded. Experience in placing the more conventional materials as well as initial costs are definitely in favor of portland-based materials.

\section{Recommendations (IC)}

Several unanswered questions relating to resin- and portland-based materials were mentioned in the Conclusions (IC) section above. The following research is needed to provide the necessary answers:

(1) Concentrated study of the tensile stress-strain relationship, tensile and compressive strengths, thermal expansion, and thermal conductivity of one type of resin with one type of lightweight aggregate. A range of densities of this material would be required. Without this information, thermal stresses expected from an LNG spill could cause fractures and lead to an unacceptable LNG boil-off rate. These data should cover the temperature range from $100 \mathrm{~K}$ to ambient. The properties mentioned must be determined on specimens which are large compared to aggregate dimensions.

(2) Tests involving large slabs of the selected material (same resin and aggregate type as selected for study in (1) above) should be done to 
compliment the property determinations discussed in project (1). Placing, large scale batching, and batch-to-batch uniformity would be determined. Specimens for the study in (1) would ideally come from these mixes. Aging in outdoor environments and effects of thermal shock would be assessed.

(3) Programs similar to (1) and (2) are needed for a portland-cement-based material with one type of aggregate. In addition to the previously mentioned parameters, effectiveness of techniques to prevent water absorption should be examined. Quantitative rates and equilibrium levels of moisture would be determined.

(4) Flammability tests are needed for the particular resin chosen. Types of gases evolved during combustion should be determined.

(5) The economics involved in choosing either type of material or combinations thereof should be studied as functions of site particulars. Relative costs of capping, substrate type, maintenance, and drainage facilities are needed and must be expressed in a form which can be related to widely variable site particulars.

A single, best material for use in insulating dikes and impounding areas cannot be selected based on available information. Our assessment indicates that there are six types of materials which would be useful in particular circumstances: (1) expanded shale/portland, (2) perlite/portland, (3) polymer/perlite, vermiculite, expanded shale or expanded clay, (4) polymer/glass, (5) portland/ polystyrene, and (6) vermiculite/portland. Although data is not available to establish a figure of merit for all of these materials, (1), (3), and (4) appear to be the best alternatives. 
References (IC)

Aagaard, V. and Ladegaard, B. H. Liquefied Natural Gas Storage, Barcelona, Preload Bulletin T-39.

Adams, Ludwig (1965). Thermal Conductivity of Perlite at Low Temperature, Cryogenic Tech., 117-118.

Adams, Ludwig (1969). Thermal Conductivity of Perlite Concrete, Cryogenic Tech. $\underline{5}, 10-11$.

Alleaume, J. I. (1970). Fixed Fluid-Tight Tank or the Like and Method of Constructing Same, U.S. Patent Office, Vol. 3511003.

Altman, Von Klaus (1974). The Behaviour of Moisture in Foam-Polystyrene Concrete and Methods of Testing, Materialprufung 16, 3-6.

American Concrete Institute Detroit, MI:

Building Code Requirements for Reinforced Concrete (1963). ACI Standard 318-63.

Design and Construction of Circular Prestressed Concrete Structures (1970). Report by Committee 344 .

Lightweight Concrete (1971). ACI SP 29.

Recommended Practice for Measuring, Mixing, Transporting, and Placing Concrete (1973). ACI 304-73.

Polymers in Concrete (1973). ACI SP 40.

Polymers in Concrete (1977). Report by Committe 548.

Guide to Durable Concrete (1977). J. Am. Concr. Inst. 74, 573-592.

Guide to Concrete Floor and Slab Construction (1980). Report by Committee 302 .

Guide for Cast-in-Place Low Density Concrete (1982). Manual of Concrete Practice, Part 5, ACI 523.1R-67. 
Guide for Cellular Concretes Above $50 \mathrm{pcf}$, and for Aggregate Concretes Above 50 pcf with Compressive Strength Less than 2500 psi(1982). Manual of Concrete Practices, Part 5, ACI 523.3R-75.

API Standard 620 (1978). Recommended Storage Tanks, American Petroleum Institute, Washington, D.C.

API Standard 2510 (1978). Design and Construction of LP-Gas Installations at Marine and Pipeline Terminals, Natural Gas, Processing Plants, Refineries, Petrochemical Plants, and Tank Farms, American Petroleum Institute, Washington, D.C.

Anderson, A. R. (1978). A 65000 Ton Prestressed Concrete Floating Facility for Offshore Storage of LPG, Marine Tech. 15, 14-26. Anderson, P. J. (1971). Coefficient of Thermal Expansion Measurements of Concrete and Mortar Samples, Report to Preload Engineering Company. Andrier (1972). Concrete Floating Storage for LNG, Pipeline Gas J. 199, 75. Arafat, M. Z. (1975). Design and Construction of Prestressed LNG Storage Tanks at Staten Island, J. Prestressed Concr. Inst. 20, 22-33. Arsham, Amirikian (1963). Minimum Requirements for Thin-Section Precast Concrete Construction, ACI Standard 525-63, 1-9.

Arthur D. Little, Inc. (1974). Evaluation of LNG Vapor Control Methods, Report to American Gas Association, 1-49.

Arvidson, J. M., Sparks, L. L., and Steketee, E. (1982). Mechanical Properties of Concrete Mortar at Low Temperatures, NBSIR 82-1658, National Bureau of Standards, Boulder, CO.

ASTM Annual Book of Standards, American Society for Testing and Materials, Philadelphia, PA.

Standard C42. Obtaining and Testing Drilled Cores and Sawed Beams of Concrete, Part 14. 
Standard C78. Flexural Strength of Concrete (using simple beam with thirdpoint loading), Part 14 .

Standard C125. Concrete and Concrete Aggregates, Part 14.

Standard C177. Steady-State Thermal Transmission Properties by Means of the Guarded Hot Plate, Part 18.

Standard C192. Making and Curing Concrete Test Specimens in the Laboratory, Part 14.

Standard C215. Fundamental Transverse, Longitudinal, and Torsional Frequencies of Concrete Specimens, Part 14.

Standard C330. Lightweight Aggregates for Structural Concrete, Part 14.

Standard C332. Lightweight Aggregates for Insulating Concrete, Part 14.

Standard C469. Static Modulus of Elasticity and Poisson's Ratio of Concrete in Compression, Part 14.

Standard C496. Splitting Tensile Strength of Cylindrical Concrete Specimens, Part 14.

Standard C513. Securing, Preparing, and Testing Specimens from Hardened Lightweight Insulating Concrete for Compressive Strength, Part 14.

Standard C597. Pulse Velocity Through Concrete, Part 14.

Standard E6. Methods of Mechanical Testing, Part 10.

Aziz, M. A., Murphy, C. K., and Ramaswamy, S. D. (1979). Lightweight Concrete Using Cork Granules, Int. J. Lightweight Concr. 1, 29-33.

Bagon, C. and Frondistou-Yannas, S. (1976). Marine Floating Concrete Made with Polystyrene Expanded Beads, Mag. Concr. Res. 28, 225-229.

Batson, G. (1976). Steel Fiber Reinforced Concrete, Mater. Sci. Eng. 25, 53-58. Berger D. (1972). Drying of Hygroscopic Capillary Porous Solids--A Theoretical Approach, Int. J. Heat Mass Transfer 16, 293-302. 
Serger, E., debris, P., and Meyer, D. (1976). Offshore Natural Gas Production by Liquefaction, Storags and Unloading on a Semi-Submersible Platform. Petroleun Times $80,29-32$.

Berger, E. (1978). Latural Gas Liquefaction Plants at Sea, Linde Report on Sci. and Tech. $27,3-10$.

Bermanger, C. and Sarkar, A. F. (1976). Themal Expansion of Concrete and Reinforced Concrete, 3. A- Concr. Inst. $73,618-621$.

Blakey, F. A. and Wattson, E. M. (1958). Perlite Concrete, Comoninealth ScienLific and Industrial Research Organization, Division of Building Research (Australia) Report C3.1-1.

Blanchette, R. L. (1971). Expanded Poiystyrene Concrete, BLSF Canada Ltd., Montreal, Quebec.

van 3reugei, K. (1982). A Designers Perspective on Cryogenic Storaga Systens for Licuefied Industrial Gases, Cryogenics 22, 331-34. Brewer Engineering laboratories (1978). Detemination of Coefficient of Themal Expansion of Concrete Sarples, Report 633. Brewer, H. K. (1955). Moisture Migration--Concrete Slab-on-Ground Construction, 3. of PCA I, 2-17.

Brewer, H. H. (1957). General Relation of Heat Flow Factors to the Unit Weight of Concrete, J. of PCA $\underline{9}, 48-60$. Bruggeing, A. C. S. (1982). State-of-the-Art Report--Cryogenic Behavior of Materials for Prestressed Concrete, Federation Internationale de la Precontrainte.

Buck, A. D. (1976). Investigation of Frost Resistance of Mortar and Concrete. W.5. Any Engineer hatemways Experinent station, Tech. Rept. C-75-4. Carpbell-Alien, D. and Thorne, C. P. (2953). The Theral Conductivity of Concrete, Mag. Concr. Res. $15,39-48$.

Carino, M. J. (1981). Te-perature Effects on Strength-Waturity Pelations of Mortar, KBSIR 81-2244, lational Bureau of Standards, hashington, D.C. 
Carpenter, L. R., Cowan, W. C., and Spencer, R. W. (1973). Polymer-Impregnated Concrete Tunnel Support and Lining, U.S. Bureau of Reclamation, Report RECEDC-73-23.

Chitharanjan, N., Ramakrishnan, V. S., and Ganesan, W. (1978). A New Production Technology for the Manufacture of Cellular Concete, Indian Concr. J. 52, $266-271$

Chung, H. W. (1978). How Good is Good Enough--A Dilema in Acceptance Testina of Concrete, J. Am. Concr. Inst. 75, 374-379.

Closner, J. J. (1968). Prestressed Concrete Storage Tanks for LNG, The Preload Company, Garden City, NY.

Closner, J. J. (1968). LNG Storage with Prestressed Concrete, The Preload Company, Garden City, NY.

Closner, J. J. (1971). Prestressed Concrete Dike Systems for LNG Storage Containers, Pipeline Gas J. 198, 63-69.

Closner, J. J. (1972). Prestressed Concrete for LNG-Status and Development Report, Proc. Cryo-71 Conf. 4 , 80-88.

Closner, J. J., Corvine, R. H., and Marchaj, T. J. (1976). Purging, Cooldown, Performance Testing of Prestressed Concrete LNG Containers, Preload Technology Inc. and American Gas Association.

Closner, J. J., DeBock, L.F., Legatos, N. A., Marchaj, T. J., and Gerwick, B. C. (1973). Prestressed Concrete for the Transport of Liquefied Natural Gas, ASME 73-PET-37, 1-9.

Closner, J. J. and Marchaj, T. J. (1975). Prestressed Concrete for Primary Storage of LNG and LPG on Ships or Barges and as a Secondary Barrier, The Preload Company, Garden City, NY.

Concrete Manual (1979). U.S. Government Printing Office, Washington, D.C. Cook, D. J. (1972). Expanded Polystyrene Beads as Liahtweight Aggregate for Concrete, UNICIV Report \#R-96, University of New South Wales, Australia. 
Cook, D. J. (1972). Polystyrene Aggregates, Constr. Rev. 45, 52-53.

Cook, D. J. (1973). Expanded Polystyrene Beads as Lightweight Aggregate for Concrete, Precast Concr., 601-603.

Cook, D. J. (1973). The Thermal Conductivity of Fiber-Reinforced Concrete,

UNICIV Report \#R-119, University of New South Wales, Australia.

Cowan, W. C. (1975). Structural Properties of Concrete-Polymer Material s: A Summary Report, U.S. Bureau of Reclamation, Report GR-2-75.

Cuperus, N. J. (1980). Developments in Cryogenic Storage Tanks, 6th Int. Conf. on LNG.

Data bases

COMPENDEX: Engineering Information, Inc., New York, NY.

INSPEC: Institute of Electrical Engineers, London, ENgland.

NTIS: National Technical Information Service, U.S. Department of Commerce, Springfield, VA.

SSIE; Smithsonian Science Information Exchange, Washington, D.C.

DePuy, G. W. (1975). Full-Scale Fabrication and Testing of Polymer-Impregnated

Concrete, First International Congress on Polymer Concretes, The Concrete

Society, London, England.

DePuy, G. W. (1975). Process Technology Developments with Concrete-Polymer Materials, U.S.Bureau of Reclamation, Report GR-4-75.

DePuy, G. W. (1975). Monomers and Polymers for Concrete-Polymer Materials, U.S.

Bureau of Reclamation, Report GR-5-75.

DePuy, G. W. (1981). Concrete Polymer Materials in the U.S, In Report on Special

Concretes, ed. C. D. Pomeroy, Cement and Concrete Association, U.K.

DePuy, G. W. (1978). Polymer Concrete, Trials and Tribulations, Second International Conference on Polymer Concretes, Austin, TX. 
Dikeou, J. T. and Steinberg, M. (1972). Concrete-Folymer Material s--Fourth Topical Report, REC-ERC-72-10 and BNL 50328, ed. L. E. Kukacka, Brookhaven National Laboratory, and G. W. DePuy, U.S. Bureau of Reclamation. Dinulescu, H. A. and Eckert, E. R. G. (1979). Analysis of the One-Dimensional Moisture Migration Caused by Temperature Gradients in a Porous Medium, Int. J. Heat Mass Transfer 23, 1069-1078.

Double, D. D. and Hellawel1, A. (1977). The Solidification of Cement, Sci. Am. $237,82-90$.

Duffy, A. R. and Shoup, A. J. (1956), 60,000-bbl LNG Tank to Use Internal InsuTation, Flexible Lines, 0i1 Gas J. 64, 114.

Durr, Charles (1974). Process Techniques and Hardware Uses Outlined for LNG Regasification, 0il Gas J. 12, 56-66 and Gas World 179, 615-625.

Dycon Concrete Thermal Grade (1973). Koppers Company, Pittsburah, PA.

Dycon Concrete: The Energy Saving Insulation for Roof Decks (1976). Koppers Company, Pittsburgh, PA.

Eakin, B. E., Bair, W. G., Closner, J. J., and Maroti, R. (1963). Below Ground Storage of Liquefied Natural Gas in Prestressed Concrete Tanks, AGA TR-8, American Gas Association, New York, NY.

Eckert, E. R. G. and Faghri, M. (1980). A General Analysis of Moisture Migration Caused hy Temperature Differences in an Unsaturated Porous Medium, Int. J. Heat Mass Transfer 23, 1613-1623.

Elices, M. and Planas, J. (1982). Measurement of Tensile Strengths of Concrete at Very Low Tempertures, J. Am. Concr. Inst. 79, 195-200.

Emanuel, J. H. and Hulsey, J. L. (1977). Prediction of the Thermal Coefficient of Expansion of Concrete, J. Am. Concr. Inst. 74, 149-155. 
Escalante, E. and Cohen, M. (1980). Measuring the Rate of Corrosion of Reinforcing Steel in Concrete, NBSIR 80-2012, National Bureau of Standards, Washington, D.C.

Escalante, E. and Ito, S. (1979). A Bibliography on the Corrosion and Protection of Steel in Concrete, NBSIR SP-550, National Bureau of Standards, Washington, D.C.

Federal Register (1980). Flammable Vapor-Gas Dispersion Protection, Federal Register Rules and Regulations 45, paragraph 193.2059, pp. 9207-9208.

Federal Register (1980). Liquefied Natural Gas Facilities; New Federal Safety Standards 45, Research and Special Programs Administration, Dept. Of Transportation, Washington, D.C.

Federal Register (1980). Liquefied Natural Gas Facilities; Reconsideration of Safety Standards for Siting, Design, and Construction 45, Research and Special Programs Administration, Dept. of Transportation, Washington, D.C. Fontana, J. J., Webster, R., and Kukacka, L. E. (1978). Rapid Patching of Deteriorated Concrete IJsing Polvmer Concrete, BNL Report, Vo1. 24217, Brookhaven National Laboratory, Upton, NY.

Forder, C. (1975). Lightweight Concrete's Place in the Insulation Spectrum, Concrete $\underline{9}, 28-30$.

Frohnsdorff, G. (1979). Possible Contributions of Cement and Concrete Technology to Energy Conservation, NBS SP-542, National Bureau of Standards, Washington, D.C.

Gibson, G. H. and Walters, W. J. (1970). Some Aspects of LNG Storage, Proc. Second Int. LNG Conf. 1 .

Gondouin, M. and Murat, F. (1972). Transportation and Storage of LNG, Chemical

Eng. Prog. $68,71-75$. 
Goto, Y. and Miura, T. (1978). Mechanical Properties of Concrete at Very Low

Temperatures, In Proceedings of 21st Japan Congress on Materials Research, 157-150, Society of Materials Science, Kyoto, Japan.

Goto, Y. (1979). Summary of Reinforced Concrete at Very Low Temperatures, In

Proceedings of Japan Society of Civil Engineers, Japan Concrete Institute, Tokyo, Japan.

Harmathy, T. Z. and Allen, L. N. (1973). Thermal Properties of Selected Masonry Unit Concretes, J. Am. Concr. Inst. 70, 132-142.

Haynes, H. H. and Eckroth, W. V. (1979). Lightweight Concrete Using Polymer-

Fluid Aggregate for Ocean Applications--An Exploratory Investigation, U.S. Navy Tech. Note, TN 1565, Dept, of Navy, Washington, D.C.

Haynes, H. H. and Rail, R. D. (1980). Lightweight Concrete Using Polymer Filled Aggregate for Ocean Applications, U.S. Navy Report 219.689, Dept. of Navy, Office of Naval Research, Arlington, VA.

Hendriks, N. A. (1978). Storage Tank Having a Protective Wall Construction, United States Patent Office, Vol . 4,096,642.

Hendriks, N. A. (1978). Safety Wall for a Storage Tank, United States Patent Office, Vo1 . 4,074,485.

Heydemann, G. and Maubke, N. Y. (1967). Method for the Determination of Pore Size Distribution in Concrete, Materialprufung $\underline{9}$, 231-233. Hickey, K. B and Arney, D. 0. (1968). Thermal Properties of a Structural Concrete at Elevated Temperatures, U.S. Bureau of Reclamation, Report C-1282. Holman, O. B. and Post, H. J. (1974). Unique Design Features-Philadelphia Gas Works' LNG Plants, Presented at the AGA Distribution Conference, Minneapolis, MN, sponsored by American Gas Association, Arlington, VA. Horler, D. B. (1977). Some Advantages of Lightweight Aggregates, Precast Concr., $137-140$. 
Horler, D. B. (1979). Lightweight Aggregates in the U.K., Intl. I. Lightweight Concr. $1,35-37$.

Houghton, D. L. (1972). Recommended Practice for Measuring, Mixing, Transporting, and Placing Concrete, J. Am. Concr. Inst. 69, 374-414. Huang, C. L. D. (1979). Multi-Phase Moisture Transfer in Porous Media Subjected to Temperature Gradient, Int. J. Heat Mass Transfer 2?, 1295-1307. Hundt, J. (1978). Heat and Moisture Flow in Concrete as a Function of Temperature, NASA Tech. Memorandum, Vo1. 75286, National Aeronautics and Space Administration, Washington, D.C.

Hutter, L. J. (1969). Insulating Foundation, United States Patent Office, Vo1. $3,473,689$.

K1ieger, P. (1952). Studies of the Effect of Entrained Air on the Strength and Durability of Concretes Made with Various Maximum Sizes of Aggregates, Proc. Highway Res. Board 31, 177-202. Also available as PCA Bulletin 40, Portland Cement Association, Skokie, IL.

Kordina, K., and Neisecke, J. (1978). Determination of the Service Properties of Concrete and Prestressing Steel at Extremely Low Temperatures, Betonverk Fertigtei1-Tech. $\underline{4}, 191-197$.

Kukacka, L. E. (1973). Perlite Polymer Concrete, J. Concr. Soc. $\underline{7}, 2.8-33$. Kukacka, L. E. (1977). The Applicability of Concrete Polymer Materials for Use in Geothermal Environments, BNL 22684, International Symposium on 0i1field and Geothermal Chemistry, Brookhaven National Laboratory, Upton, NY. Kukacka, L. E. (1977). Concrete Polymer Materials, Production Methods and Applications, BNL 23497, Brookhaven National Laboratory, Upton, NY. Kukacka, L. E. (1978). Polymer Concrete Materials for Use in Geothermal Energy Processes, BNL 24214, Brookhaven National Laboratory, Upton, NY. 
Kukacka, L. E., Auskern, A., Colombo, P., Fontana, J. and Steinberg, M. (1974). Introductory Course on Concrete-Polymer Materials, BNL 19525, Brookhaven National Laboratories, Upton, NY.

Kukacka, L. E., DePuy, G. M. (1973). Concrete-Polymer Material s, BNL 50390, Brookhaven National Laboratories, Upton, NY.

Kukacka, L. E., Fontana, J., and Steinberg, M. (1975). Concrete-Polymer Materials for Highway Applications, BNL 50462, Brookhaven National Laboratories, Upton, NY.

Kukacka, L. E. and Fontana, J. (1977). Polymer Concrete Patching Materials, DoT 77-11, Vol. I, Dept. of Transportation, Washington, D.C.

Kukacka, L. E. and Fontana, J. (1977). Polymer Concrete Patching Materials. DoT 77-11, Vo1. II, Dept. of Transportation, Washington, D.C.

Kukacka, L. E., Mediatore, R., Fontana, J., Steinberg, M. and Levine, A. (1975). The Use of Polymer-Concrete for Bridge Deck Repairs on the Major Deegan EXpressway, BNL 19672, Brookhaven National Laboratory, Upton, NY.

Lacey, W. G. (1975). A Low Temperature Gradient Method of Measuring the Thermal Conductivity of Micro-Concrete, MS Thesis South Dakota School of Mines and Technology, Rapid City, SD.

Lal, K., Singh, R., and Upadhyaya, V. G. (1976). Bloated Clay an Unconventional Artificial Lightweight Aggregate, Indian Concr. J. 50, 174-180.

Lang, R. Z. J., Moorhouse, J., and Paul, G. J. (1980). Waterproof Insulation Materials, Presented at Institute of Chemical Engineer's 7th Symposium on Process Hazards, Manchester, U.K., Al so British Gas Report MRS 372, British Gas Corp., Solihul1, U.K.

Lentz, A. E. and Monfore, G. E. (1965). Thermal Conductivity of Concrete at Very Low Temperatures, J. PCA $\underline{6}, 3.9-46$. 
Lentz, A. E. and Monfore, G. E. (1966). Thermal Conductivities of Portland Cement Paste, Aggregate and Concrete Down to Very Low Temperatures, J. PCA $\underline{8}, 27-33$.

Lindstrom, R. and Milgrom, J. (1972). Glass Polymer Composite Sewer Pipe--An

Initial Evaluation of Its Commercial Potential, ADL Report C74228, Arthur D. Little, Inc., Cambridge, MA.

Loudon, A. G. (1979). The Thermal Properties of Lightweight Concretes, Intl .

J. Lightweight Concr. $1,71-85$.

Lydon, F. D. (1969). The Problem of Water Absorption by Lightweight Aggregates, Mag. Concr. Res. 21, 131-140.

Lydon, F. D. (1972). Thermal Insulation, Concrete, 31-34.

Lyer, L. S. and Mahadevan, A. (1981). Polymer Concrete and Its Applications, SAMPE Quarterly $\underline{12}, 33-35$.

Malhotra, V. M. (1970). Effect of Specimen Size on Tensile Strength of Concrete, J. Am. Concr. Inst. 67, 467-469.

Mansor, J. A. (1976). Modifications of Concretes with Polymers, Mat. Sci.

Eng. 25, 41-52.

Marechal, J. C. (1972). Thermal Conductivity and Thermal Expansion Coefficients of Concrete as a Function of Temperature and Humidity, ACI SP 34, American Concrete Institute, Detroit, MI, 1047-1057.

Marechal, J. C. (1972). Variations in the Modulus of Elasticity and Poisson's

Ratio with Temperature, In Concrete for Nuclear Reactors, ed. C. E. Kesler, American Concrete Institute, Detroit, MI, 495-503.

Marsha11, A. L. (1982). Cryogenic Concrete, Cryogenics 22, 555-565.

Marsha11, A. L. (1978). Concrete for Marine Transport and Storage of Cryogenic

Liquids, In Proceedings of European Offshore Petroleum Conference and Exhibit 1 , London, 225-232. 
Materials Transportation Bureau (1980). Liquefied Natural Gas Facilities; New

Federal Safety Standards, Federal Register 193.

McClune, C. R. and Moorhouse, J. (1981). The Development of Waterproof Insu-

lating Materials Based on Lightweight Concrete, Mag. Concr. Res. 33, 27-36. McDonald, J.E. (1975). Moisture Migration in Concrete, ERDA Tech. Report C-75-

1, U.S. Energy Research and Development Administration, Washington, D.C. McDonald, J. E. (1972). An Experimental Study of Moisture Migration in Concrete, ACI SP 34, American Concrete Institute, Detroit, MI, 957-989. Meiner, E. (1979). LNG Storage Enclosed in Prestressed Concrete Safety Walls, 0i1 Gas J. $77,117-20$.

Mindess, S. (1979). Application of Fracture Mechanics to Cement and Concrete,

Presented at 81st Annual Meeting of the American Ceramic Society. Missenard, A. (1965). Theoretical and Experimental Research on the Heat Conductivity of Concrete, BR translation 638, U.S. Bureau of Reclamation, Denver, Cn. Translation from Annales de L'Institut Technique du Batiment et des Travaux Publics 18, 950-967.

Monfore, G. F. and Lentz, A. E. (1962). Physical Properties of Concrete at Very Low Temperatures, J. PCA $\underline{4}, 33-39$. Moore, J. P., Graves, R. S., Standley, J. G., Hannah, J. H., and McElroy, D. L. (1969). Some Thermal Transport Properties of a Limestone Concrete, ORNL-TM2644, Dak Ridge National Laboratory, Oak Ridge, TN. Muller-Rochholz, J. (1979). Investigation of the Absorption of Water by Lightweight Aggregate from Cement Paste, Int1. J. Lightweight Concr. 1 , 39-41. Neison, C. A. (1975). Application Developments of Concrete-Polymer Materials, U.S. Bureau of Reclamation, Report GR-3-75. 
Nekrason, K. D. and Maslennikoua, M. G. (1962). Heat Resistant Perlite Concrete, Beton Zhelezobeton $\underline{8}, 339-342$.

NFPA (1972). Storage and Handling Liquefied Petroleum Gases, NFPA 58, National Fire Protection Association, Inc., Boston, MA.

NFPA (1972). Storage and Handling Liquefied Natural Gas, MFPA 59A, National Fire Protection Association, Inc., Boston, MA.

NFPA (1979). Storage and Handling Liquefied Natural Gas, NFPA 59A, National Fire Protection Association, Inc., Boston, MA.

NFPA (1981). Flammable and Combustib?e Liquids Code, NFPA 30, National Fire Protection Association, Inc., Boston, MA.

Nielsen, A. F. (1972). Gamma-P.ay-Attenuation Used for Measuring the Moisture

Content and Homogeneity of Porous Concrete, Build. Sci. $\underline{7}, 157-263$.

Pacini, G. C. (1975). Cryogenic Insulation in Europe, In Proceedings of Perlite

Institute Annual Meeting, Athens, Greece, 58-70.

Packard, R. G. (1976). Slab Thickness Design for Industrial Concrete Floors on

Grade, PCA IS195.010, Portland Cement Association, Skokie, IL.

Parsons, W. H. and Johnson, W. H. (1944). Factors Affecting the Thermal Expan-

sion of Concrete Materials, J. Am. Concr. Inst. 15, 457-466.

Perlite Institute, Inc. Perlite Insulating Concrete, PI Catalog 30, Perlite Institute, Inc., New York, NY.

Perlite Institute, Inc. (1979). Application and Design Information for Contractors, PI 32-79, Perlite Institute, Inc., New York, NY.

Petsinger, R. E. (1967). LNG on the Move, Gas 43, 45-49.

Pfeifer, D. W. (1969). Fly Ash Aggregate Lightweight Concrete, PCA R\&D Bulletin,

Vol. RD003.01T, Portl and Cement Association, Skokie, IL. 
Pittsburgh Testing Lab (1963). Perlite Concrete Testing Program for Perlite Institute, Inc., PI Report, Perlite Institute, Inc., New York, NY.

Poad, M. E., Serbousek, M. 0., and Goris, J. (1975). Engineering Properties of Fiber-Reinforced and Polymer-Impregnated Shotcrete, Report 8001, U.S. Bureau of Mines, Spokane Mining Research Center, Spokane, WA.

Portland Cement Association (1968). Design and Control of Concrete Mixtures, PCA Engineering Bulletin.

Portland Cement Association (1973). Report on Fiberglass Reinforced Cellular Concrete Phase I, General Physical Properties, PCA Report, Portland Cement Association, Skokie, IL.

Portland Cement Association (1973). Report on Fiberglass Reinforced Cellular Concrete Phase II, Cracking Resistance, PCA Report, Portland Cement Association, Skokie, IL.

Portland Cement Association (1974). Report on Fiberglass Reinforced Cellular Concrete Phase III, Drying Shrinkage and Creep, PCA Report, Portland Cement Association, Skokie, IL.

Powers, T. C. (1954). Void Spacing as a Basis for Producing Air-Entrained Concrete, J. Am. Concr. Inst. $25,741-760$.

Precast Concrete (1975). Lightweight (and Liahter) Concrete, Precast Concr. $\underline{6}$, 653-655.

Preload Technology, Inc. (1972). Comparison of Down Wind Vapor Travel from LNG Spills with Different Dike Systems, The Preload Company, Garden City, NY. Reichard, T. W. (1964). Creep and Dryina Shrinkage of Lightweight and Normal Weight Concrete, NBS Monograph 74, National Bureau of Standards, Washington, D.C.

Reid, R. C. and Wang, R. (1978). The Boiling Rates of LNG on Typical Dike Floor Materials, Cryogenics 18, 401-404. 
Reid, R. C. (1980). Boiling of LNG on Typical Dike Floor Materials, Report to Sponsor, GRI-79/0026, Gas Research Institute, Chicago, IL.

Reinhardt, P. (1974). Temperature Stresses in Prestressed Concrete Walls of Containment Structures, J. Prestressed Concr. Inst. 19, 76-85. Reinker, R. P., Timmerhaus, K. D., and Kropschot, R. H. (1979). Selected Porous Insulations for Cryosystems, ASHRAE J. 21, 21-26. Richard, T. G. (1977). Low Temperature Behavior of Cellular Concrete, J. Am. Concr. Inst. $74 \cdot 173-178$. Richard, T. G., Dobogai, J. A., Gerhardt, T. D., and Young, W. C. (1975). Cellular Concrete--A Potential Load-Bearing Insulation for Cryogenic Applications, IEEE Trans. on Magn. MAG-11, 500-503. Rostasy, F. S. and Wiedemann, G. (1980). Stress-Strain-Behavior of Concrete at Extremely Low Temperatures, Cem. Concr. Res. 10, 565-572. Rostasy, F. S., Weib, R., and Wiedemann, G. (1980). Changes of Pore Structure of Cement Mortars Due to Temperature, Cem. Concr. Res. 10, 157-164. Rostasy, F. S., Schneider, U., and Wiedemann, G. (1979). Behavior of Mortar and Concrete at Extremely Low Temperatures, Cem. Concr. Res. 9, 365-376. Saemann, J. C. and Washa, G. W. (1957). Variation of Mortar and Concrete Properties with Temperature, J. Am. Concr. Inst. 2.9, 385-3.95. Sather, W. R. (1974). Fibrous Concrete Field Batching Sequences, J. Am. Concr. Inst. 21, 504-505.

Scoggin, H. L. (1966). Cast-in-Place Concrete Residences with Insulated Walls, J. PCA $\underline{8}, 21-29$. Selander, C. E. (1975). Development of Concrete-Polymer Materials by the Bureau of Reclamation, BR GR-1-75, U.S. Bureau of Reclamation, Denver, CO. Sherwood, T. K. (1931). Application of Theoretical Diffusion Equations to the Drying of Solids, Chem. Eng. Prog. 27, 190-202. 
Short, A. and Kinniburch, W. (1963). Lightweight Concrete, C. R. Books Limited, John Wiley a Sons, Inc.

Slobodanik, I. Y. (1968). Expanded Perlite Fines, The Concrete Society, First International Congress on Lightweight Concrete $\underline{2}$.

Sparks, L. L. (1981). Thermal Conductivity of a Concrete Mortar from $95 \mathrm{~K}$ to 320 K, NBSIR 81-1651, National Bureau of Standards, Boulder, C0. Sparks, L. L. (1983). Specific Heat in Materials at Low Temperatures, in Materials at Low Temperatures, eds. R. P. Reed and A. F. Clark, American Society for Metals, Metals Park, $\mathrm{OH}, 69$.

Staff, 0il and Gas Journal (1970). Prestressed Concrete LNG Tanks Tested, in Operation, 0i1 Gas J. 68, 95-6.

Staff, Oil and Gas Journal (1976). Concrete Due Test as Barrier in Marine LNG Service, 0il Gas J. $\underline{74}$, 64-6.

Staff, Pipeline and Gas Journal (1982). Scorecard, Pipeline Gas J. 80, 32-42. Staff, Plastics-Rubbers-Textiles (1970). Void Forming in Concrete with Expanded Polystyrene, Plastics-Rubbers-Textiles 1, 331-332.

Staff Report (1972). Concrete LNG Storage Tank Uses Mastic Gas Barrier, Pipeline Gas J. $199,59-61$.

Staff, Shipping World and Shipbuilding (1976). The Dytam Design of a Concrete Constructed LNG Carrier, Shipp. World Shipbuild, 169, 1021-1022.

Staff, Western Engineer (1983). On Concrete Durability. Western Engineer 67, $19-21$.

Steiger, R. Wo and Hurd, M. K. (1978). Lightweight Insulating Concrete for Floors and Roof Decks, Concr. Constr. 23, 411-422.

Steinberg, M., Kukacka, L. E., Colombo, P., Kelsch, J. J., Manowitz, B., Dikeou, J. T., Backstrom, J. E., and Rubenstein, S. (1968). Concrete-Polymer Materials, BNL 50134, Brookhaven National Laboratory, Upton, NY. 
Steinberg, M., Kukacka, L. E., Colombo, P., Auskern, A., Manowitz, B., Dikeou, J. T., Backstrom, J. E., Kickey, K. B., Rubenstein, S., and Jones, C. W. (1969). Concrete-Polymer Materials--Second Topical Report, BNL 5:218, Brookhaven National Laboratory, IJpton, NY.

Steinberg, M. (1971). Concrete-Polymer Materials Development--A Goal-Oriented

Program, BNL 50313, Brookhaven National Laboratory, Upton, NY.

Steinberg, M. (1976). Concrete Polymers: Past, Present and Future, BNL 22524, Brookhaven National Laboratory, Upton, NY.

Stiles, R. E. (1970). Worlds Largest Above Ground Storage Tank in Operation, Pipeline Industry 32, 41-43.

Stockhausen, N., Dorner, H., Zech, B., and Setzer, M. J. (1979). Freezing Phenomena in Hardened Cement Paste Were Investigated by DTA, Cem. Concr. Res. $\underline{9}, 783-794$.

Strom, 0. G. (1965). Accelerated Strength Testing of Lightweight Concrete Cylinders, Thesis, University of Wyoming, Civil and Architectural Engineering, Laramie, WY.

Sugawa, T., Kukacka, L. E., and Horn, W. (1981). Water-Compatible Polymer Concrete Materials for Use in Rapid Repair Systems for Airport Runways, BNL 51390, Brookhaven National Laboratory, Upton, NY.

Sugisaki, M., Suga, H., and Seki, S. (1969). Calorimetric Study of Glass Transition of the Amorphous Ice and of the Phase Transformation Between the Cubic and the Hexagonal Ices, Physics of Ice, Plenum Press, New York, NY.

Sussman, U. (1975). Lightweight Plastic-Aggregate Concrete, J. Am. Concr. Inst. $72,321-323$.

Taylor, W. H. (1949). Foamed Concrete, CSIRO C1-1, Commonwealth Scientific and Industrial Research Organization, Building Research Lah., Australia. 
Taylor, W. H. (1954). Lightweight Concrete, CSIRO Report, Commonweal th Scientific and Industrial Research Organization, Building Research Lab., Australia.

Teychenne, D. C. (1968). Lightweight Aggregates and Their Properties and Use in Concrete in the United Kingdom, The Concrete Society, First International Congress on Lightweight Concrete 1 .

Thompson, N. E. (1968). A Note on the Difficulties of Measuring the Thermal Conductivity of Concrete, Mag. Concr. Res. 20, 45-49.

Tognon, G. (1968). Behavior of Mortars and Concretes in the Temperature Range from $+20^{\circ} \mathrm{C}$ to $-196^{\circ} \mathrm{C}$, Supplementary Paper III-24, Cement Association of Japan, Tokyo, Japan.

Trotter, H. G., Turner, F. H., Sullivan, P. J. E., and Brooks, W. T. (1975). Behavior of Prestressed Concrete Matrials at Very Low Temperatures, Build. Int. $8,65-81$.

Tye, R. P. and Spinney, S. C. (1976). Thermal Conductivity of Concrete: Measurement Problems and Effect of Moisture, Bull. Inst. Int. Froid, Annexe 1976-2, 119-127.

Valore, R. C. (1956). Insulating Concretes, J. Am. Concr. Inst. 28, 509-532. Valore, R. C. (1954). Cellular Concretes, Part 1: Composition and Methods of Preparation, J. Am. Concr. Inst. 25, 773-795.

Valore, R. C. (1954). Cellular Concretes, Part 2: Physical Properties, J. Am. Concr. Inst. 25, 817-836.

VanLangen, J. R. (1973). LNG Liquefaction Plants and Associated Shoreside Operations, NMRC Com-75-10469, National Maritime Research Center, Kings Point, NY.

VonFerdinand, S., Rostasy, F. S., and Wiedemann, G. (1980). Festigkeit und Verfounceng von Beton bei Sehr Tiefer Temperatur, Beton 3n, 54-59. 
Weigler, H. and Sieghart, K. (1980). Structural Lightweight Aggregate Concrete with Reduced Density-Lightweight Aggregate Foamed Concrete, Int1. J. Lightweight Concr., 101-104.

Welgler, H. and Nicolay, J. (1973). Temperaturdehn-und Warmeleitzahlen von Gefugedichtem Leichtbeton, Beton 23, 486-490.

West, J. M., Majumdar, A. J., and DeVekey, R. D. (1980). Polymer Impreanated

Lightweight GRC, Composites 11, 169-174.

Whiting, D., Litvin, A., and Goodwin, S. E. (1978). Specific Heat of Selected Concretes, PCA RD058.01B, Portland Cement Association, Skokie, IL. Wi1ls, M. H., Jr. (1974). Lightweight Aggregate Particle Shape Effect on Structural Concrete, J. Am. Concr. Inst. 71, 134-142.

Wischers, G. (1970). Behavior of Concrete at Very Low Temperatures, Beton, Herst11erng, Verwertung 20, 135-139.

Yasin, Y. D. (1972). Comparative Evaluation of Methods Used for Determining the Cryogenic Phase Transformations of Moisture in Construction Materials, J. Eng. Phys. (USSR) 23, 907-908.

Yoshiwa, M. and Iwata, A. (1977). Performance Characteristics of an Apparatus Based on the Curve-Fitting Method for Measuring Thermal Properties at Cryogenic Temperatures, Cryogenics 17, 273-282.

Ziembicka, H. (1977). Effect of Micropore Structure on Cellular Concrete Shrinkage, Cem. Concr. Res. 7 , 323-332. 
Expanded shale/portland

Monfore, G. E. and Lentz, A. E. (1962). Physical Properties of Concrete at Very Low Temperatures, J. PCA $\underline{4}, 33-39$.

Narrative: The properties of various concretes were reported by the authors in the period 1962 through 1966. This work is referred to in a large percentage of papers dealing with concrete at low temperatures. The purpose of their study was to develop a data base to use in the design of LNG facilities. The temperature range studied was -157 to $24{ }^{\circ} \mathrm{C}$. The materials of primary interest were ordinary weight concretes, e.g., densities on the order of $2290 \mathrm{~kg} / \mathrm{m}^{3}\left(143 \mathrm{lb} / \mathrm{ft}^{3}\right)$. One series of expanded-shale-portland specimens were included; the density of these specimens was $1554 \mathrm{~kg} / \mathrm{m}^{3}\left(97 \mathrm{ib} / \mathrm{ft}^{3}\right)$ which puts them in the structurallightweight category.

Material: Expanded shale/portland; $1554 \mathrm{~kg} / \mathrm{m}^{3}\left(97 \mathrm{lb} / \mathrm{ft}^{3}\right)$ density; $\overline{334.5 \mathrm{~kg}} / \mathrm{m}^{3}\left(6.0 \mathrm{bag} / \mathrm{yd}^{3}\right)$ cement content; $0.45 \mathrm{l} / \mathrm{kg}(5.1 \mathrm{gal} / \mathrm{bag})$ water to cement ratio.

Data: Young's modulus (moist condition); $-157 \leq T \leq 24{ }^{\circ} \mathrm{C}$. Thermal contraction (moist condition); $-157 \leq T \leq 24{ }^{\circ} \mathrm{C}$. Compressive strength (moist condition); $-157^{\circ} \leq T^{-} \leq 24{ }^{\circ} \mathrm{C}$. Splitting strength (moist condition); $-157 \leq \bar{T} \leq \overline{24}{ }^{\circ} \mathrm{C}$.

Conclusions. Compressive strength, compressive modulus, and splitting strength show essentially no temperature dependence on temperatures above $0{ }^{\circ} \mathrm{C}$. Below this temperature, each increases rapidly with decreasing temperature. Splitting strength exhibits a maximum at $-58{ }^{\circ} \mathrm{C}$ while the compressive strength and modulus continue to increase monotonically as temperature decreases. These trends were also observed for a moist concrete mortar by Arvidson, Sparks, and Steketee (1982). Thermal contraction al so exhibits an inflection at about $-58{ }^{\circ} \mathrm{C}$. This behavior has been observed for other types of concrete (Tognon, 1968; Goto and Miura, 1978). 
Lentz, A. E. and Monfore, G. E. (1965). Thermal Conductivity of Concrete at Very Low Temperatures, J. PCA ㄱ, 39-46.

Narrative: This paper is the second of the series by Lentz and Monfore dealing with concretes at low temperatures. One of the materials discussed is expanded shale/portland in moist, $50 \%$ relative humidity (RH), and oven-dry conditions. The density of this material is $1586 \mathrm{~kg} / \mathrm{m}^{3}$ which falls in the structural lightweight category. These data, along with those reported in Monfore and Lentz (1962), constitute a complete set of low-temperature properties for a particular formulation and are unique in this regard.

Material: Expanded shale/portland; $1586 \mathrm{~kg} / \mathrm{m}^{3}\left(99 \mathrm{lb} / \mathrm{ft}^{3}\right)$ density; $334.6 \mathrm{~kg} / \mathrm{m}^{3}$ $\left(6.0 \mathrm{bag} / \mathrm{yd}^{3}\right)$ cement content; $0.45 \mathrm{l} / \mathrm{kg}(5.1 \mathrm{gal} / \mathrm{bag})$ water to cement ratio.

Data: Thermal conductivity (moist, $50 \% \mathrm{RH}$, oven dry); $-157 \leq T \leq 24^{\circ} \mathrm{C}$.

Conclusions: These data emphasize the importance of moisture content on the conductivity of concrete. The general rule of a $5 \%$ change in conductivity for each $1 \%$ change in density due to free-moisture content is closely followed at $-160{ }^{\circ} \mathrm{C}$. The separation of data points for these data would preclude identifying possible inflections in the -70 to $-20{ }^{\circ} \mathrm{C}$ temperature range. The possibility exists for significantly higher conductivities in this range for moist concretes. Rapid changes in splitting strength and thermal contraction were observed by Monfore and Lentz (1962) and in thermal conductivity by Sparks (1981). 
Reid, R. C. and Wang, R. (1978). The Boiling Rates of LNG on Typical Dike Floor Materials, Cryogenics 18, 401-404.

Reid, R. C. (1980). Boiling of LNG on Typical Dike Floor Materials, Final Report to Gas Research Institute, GRI-79/0026.

Narrative: Spill tests were conducted to determine the boiling parameters of several candidate dike insulating materials. The boiling rate, $M / A$, was found to be $M / A=F t^{-1 / 2}$ and $F=(k \pi C / \rho)^{-1 / 2} \Delta T / \Delta H$. Both coated and uncoated specimens were tested and no difference in boiling rates was detected. Apparent thermal conductivities were computed.

Material: Polystyrene-portland, vermiculite-portland, soil, corrugated al uminum, polyurethane.

Data: Boiling rate, thermal conductivity.

Conclusions: The relative boil-off rates for the insulating concretes were roughly proportional to density. The boiling parameter, $F$, for these materials is about a factor of two higher than that of the $120 \mathrm{~kg} / \mathrm{m}^{3}$ polyurethane foam tested, and about a factor of eight lower than the compacted soil tested. The problem of moisture uptake was not addressed. The authors found that corrugated aluminum over a sand substrate served to limit the boiling rates to about the level of the insulating concretes. 


\section{Cellular portland cement concrete}

Richard, T. G. (1977). Low Temperature Behavior of Cellular Concrete, J. Am. Concr. Inst. $\underline{74}, 173-178$.

Richard, T. G., Dobogai, J. A., Gerhardt, T. D., and Young, W. C. (1975). Cellular Concrete--A Potential Load-Bearing Insulation for Cryogenic Applications, IEEE Trans. on Magn. MAG-11, 500-503.

Narrative: The material studied is a neat-cellular concrete consisting of type I portland cement, water, and a hydrolized waste-protein-foaming agent. Several densities were prepared and properties were studied as a function of density at 23 and $-196{ }^{\circ} \mathrm{C}$.

Material: Cellular-portland-cement concrete.

Data: Specific strength as a function of water to cement ratio; ultimate compressive strength, elastic modulus, secant modulus, and thermal conductivity as functions of density.

Conclusions: The data are indicative of moist specimens which tend to make the thermal conductivity data relatively high. No indication of water uptake is given but would probably be high, at least comparable to vermiculite- and polystyrene-portland. The ratio compressive strength/thermal conductivity for a $1200 \mathrm{~kg} / \mathrm{m}^{3}$ specimen indicates that this type of material compares reasonably well with other non-resin based concretes. 


\section{Perlite-portland cement concrete}

Adams, L. (1969). Thermal Conductivity of Perlite Concrete, Cryogenic Tech. $\underline{5}, 10-11$.

Narrative: This work presents an analytical study of thermal conductivity as a function of temperature with density and free-water content as parameters.

Material: Perlite-portland-cement concrete.

Data: Analytical values of thermal conductivity in the temperature range 144 to $255 \mathrm{~K}$, free moisture content from 0 to $60 \%$, and oven-dry densities from 352 to $577 \mathrm{~kg} / \mathrm{m}^{3}$ 。

Conclusions: The values presented in this paper are useful because the anaTytical relationship is based on reasonable observations of the behavior of other materials and there are no experimental data for perlite concrete. 
Lang, R. Z. J., Moorhouse, J., and Pau1, G. J. (1980). Waterproof Insulation Materials, British Gas Corporation MRS E 372, Institute of Chemical Engineers Seventh Symposium on Process Hazards.

Narrative: This paper reports the continuation of the effort to establish a viable insulating material for dike-impounding systems of LNG-storage facilities (McClune and Moorhouse, 1981). Water uptake in outdoor exposures is reported for several treated and untreated lightweight concretes. Mass rate of boil-off of LNG is experimentally determined and used to compare the various types of specimens mentioned above with varying water contents. Results from tests to evaluate the bond strength of resin based materials to ordinary concretes are reported.

Material: Ordinary (sand and gravel aggregate) concrete, lightweight concrete, and resin concrete.

Data: Comparison of water uptake of treated and untreated lightweight concrete; LNG boil-off rates as a function of water content and as a function of time from spill; tensile bond strength of lightweight-ordinary concretes.

Conclusions: As was shown in a previous publication, resin-based concretes are superior to treated lightweight concretes with regard to water uptake and compressive strength. Data presented here for the bond strength between resin and ordinary concretes indicate that this should not be a major problem in the practical application of resin concretes. In applications where the exposure to water can be reasonably limited, such as well graded or vertical sections, the water uptake in treated lightweight concretes can be kept to levels causing relatively small increases in thermal conductivity, e.g., water content increasing from 0 to $10 \%$ by volume increases the conductivity by approximately $50 \%$. 
McClune, C. R. and Moorhouse, J. (1981). The Developinent of Waterproof Insulating Materials Based on Lightweight Concrete, Mag. Concr. Res. 33, 27-36.

Narrative: This paper considers three areas of primary interest in selecting a material for use in the dike-impounding system of LNG-storage facilities. Several methods of reducing water uptake are discussed. The most effective of these is to replace the cement binder with a resin binder. Addition of latex to the portiand cement and/or to the aggregates used is also effective. The usual relationship between the compressive strength and density was not significantly affected by the waterproofing in the case of the portland-based concretes. The resin-based materials did not follow this relationship in that their compressive strength was substantially higher than that for a portland-based concrete of comparable density. Thermal conductivity of both resin- and portland-based materials exhibit similar density dependence at $30^{\circ} \mathrm{C}$.

Materials: Aerated, polystyrene, vermiculite and expanded-clay aggregates in portland-cement binder. Epoxy and polyester binders used with several unspecified aggregates and with clay aggregates. Latex, epoxy, and silicon admixtures.

Data: Water uptake and water content as a function of time in wetting and drying environments. Compressive strength and thermal conductivity as functions of density.

Conclusions: Thermal conductivity of concretes increases roughly $5 \%$ for each $1 \%$ increase in density due to free water content. This trend makes water uptake critical to the performance of these materials. Waterproofing by application of surface sealers is not satisfactory because thin layers of sealer are not effective and thick layers are expensive and are detrimental to the thermal properties. Reactive admixtures are not effective when used with lightweight concretes. Nonreactive admixtures, particularly latex, and treatment of aggregate with waterproofing agents prior to mixing was found to be effective in reducing water uptake. Resin-based concretes were most effective in reducing water uptake. Possible drawbacks to the use of resin binders are flammability, cost, and bondability to substrate materials. 


\section{\begin{tabular}{l|l} 
5. OEP P. OF COMM. & 1. PUBLICATION OR \\
REPORT NO.
\end{tabular} \\ SHEET ( See instructions) \\ 4. TITLE AND SUBTITLA NBS IR 84-301] \\ Thermal and Mechanical Properties of Polyurethane Foams and a Survey of Insulating Concretes at Cryogenic Temperatures}

5. AUTHOR(S)

L. L. Sparks and J. M. Arvidson

6. PERFORMING ORGANIZATION (If joint or other than NBS, see instructions)

NATIONAL BUREAU OF STANDARDS

DEPARTMENT OF COMMERCE

WASHINGTON, D.C. 20234

5081-352-0425

8. Type of Report \& Period Covered

Final, Jan 1979-Feb 198 A

9. SPONSORING ORGANIZATION NAME AND COMPLETE ADDRESS (Street, City, State, ZIP)

Gas Research Institute

8600 West Bryn Mawr Avenue

Chicago, IL 60631

10. SUPPLEMENTARY NOTES

Document describes a computer program; SF-185. FIPS Software Summary, is attached.

IBSTRACT (A 200-word or less factual summary of most significant information. If document includes a significant

ibliography or literature survey, mention it here)

Thermal and mechanical properties of expanded plastics, foams, are reported. The system studied was rigid, closed cell, CC\&3F blown, polyether based polyurethane. The primary temperature range of study was 100 to $300 \mathrm{~K}$; however, several properties were determined to $4 \mathrm{k}$. The nominal densities of the foams tested were 32,64, and $96 \mathrm{~kg} / \mathrm{m}^{3}$. Properties reported are thermal conductivity, thermal expansion, strength and moduli in tension and in compression, proportional limit, yield strength, ultimate strength, and shear strength. Physical properties were determined both parailel and perpendicular to the orthogonal axes of the bulk supplies. The gas content of the specimens was determined using a gas chromatograph-mass spectrometer and with a gas displacement pycnometer. Empirical procedures for estimating the temperature dependent thermophysical properties were developed. These procedures are based on the experimental data and utilize the characterization parameters for molar gas concentration, gas pressure, and cell morphology.

Regulations affecting vapor dispersion in the area around liquefied natural gas facilities make it attractive to construct dikes and impounding areas out of materials having low thermal conductivities. Several insulating concretes have the general properties required for such applications. Screening tests were done to determine the thermal conductivity, modulus of rupture, and the compressive strength of several polyester based materials with glass bead or perlite aggregate and of portland cement based materials with vermiculite or polystyrene aggregate. A bibliography resulting from an extensive literature survey of lightweight concretes is presented. Seven of the references which were particularly applicable are presented in annotated form.

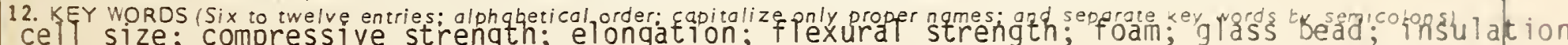
low temperature; mechanical properties; modulus of rupture; perlite; polyester; polymer concrete; polystyrene; portland cement; proportional limit; shear strength; tensile strength

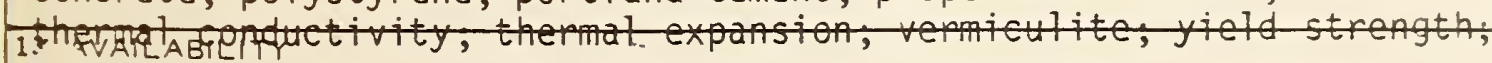

X Unlimited

$\square$ For Official Distribution. Do Not Release to NTIS

Order From Superintendent of Documents, U.S. Government Printing Office, Washington, D.C. 20402.

Order From National Technical Information Service (NTIS), Springfield, VA. 22161

14. NO. OF PRINTED PAGES $-158$

15. Price $\$ 16.00$ 
